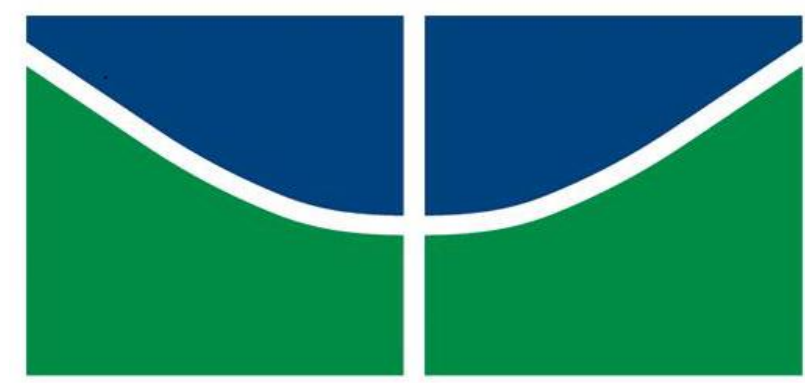

UNIVERSIDADE DE BRASÍLIA

INSTITUTO DE LETRAS

DEPARTAMENTO DE LINGUÍSTICA, PORTUGUÊS E LÍNGUAS CLÁSSICAS LIP

PROGRAMA DE PÓS-GRADUAÇÃO EM LINGUÍSTICA - PPGL

MULTILETRAMENTOS E MULTIMODALIDADE NAS PROVAS DO ENEM:

MUITO ALÉM DO TEXTO VERBAL

Joanny Daniele do Lago Costa Bento

Brasília/ DF

2017 
JOANNY DANIELE DO LAGO COSTA BENTO

MULTILETRAMENTOS E MULTIMODALIDADE NAS PROVAS DO ENEM: MUITO ALÉM DO TEXTO VERBAL

Dissertação apresentada como requisito parcial para obtenção do título de Mestra em Linguística à Banca Examinadora do Programa de Pós-Graduação em Linguística (PPGL) da Universidade de Brasília (UnB).

Orientadora: Professora Doutora Francisca Cordelia Oliveira da Silva.

Brasília/ DF

2017 


\section{MULTILETRAMENTOS E MULTIMODALIDADE NAS PROVAS DO ENEM: MUITO ALÉM DO TEXTO VERBAL}

Dissertação apresentada ao Programa de Pós-Graduação em Linguística, Departamento de Linguística, Português e Línguas Clássicas, Instituto de Letras, Universidade de Brasília, como requisito parcial para a obtenção do título de Mestra em Linguística, área de concentração Linguagem e Sociedade.

\section{BANCA EXAMINADORA}

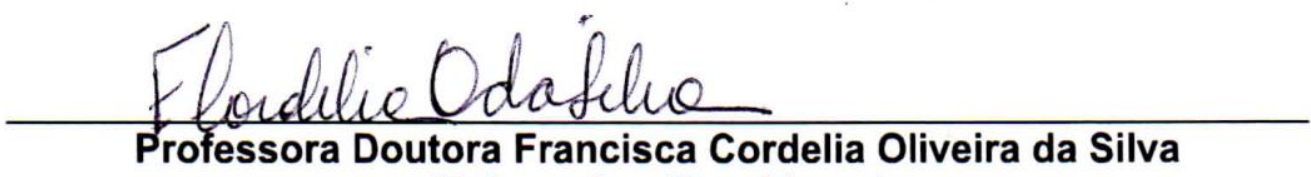
(Orientadora/Presidenta)

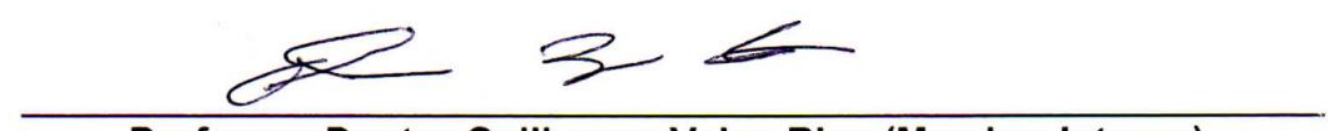

Professor Doutor Guilherme Veiga Rios (Membro Interno)

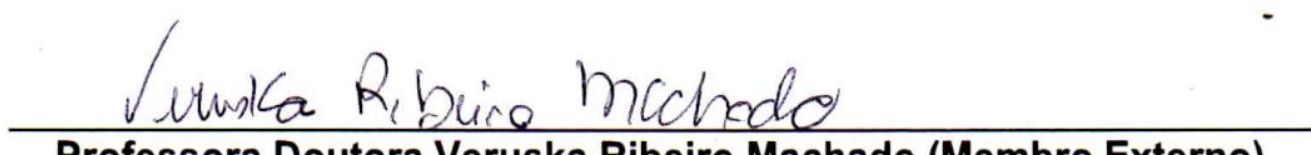

Professora Doutora Veruska Ribeiro Machado (Membro Externo)

Professora Doutora Viviane Cristina Vieira (Membro Suplente) 
"A persistência é o caminho do êxito".

(Charles Chaplin)

"Valeu a pena? Tudo vale a pena quando a alma não é pequena".

(Fernando Pessoa) 


\section{AGRADECIMENTOS}

Primeiramente a Deus, por me conceder força e sabedoria o suficiente para seguir em frente com os meus objetivos pessoais e profissionais mesmo após o período mais difícil da minha vida, a perda repentina do meu pai durante o primeiro semestre do mestrado.

Ao meu pai, que, mesmo sem sua presença física, foi fonte de inspiração por sua história de amor à leitura e aos livros; e, apesar de seu pouco estudo, foi um dos homens mais inteligentes que eu conheci; e foi exemplo de amor, carinho e determinação, o que me ajudou a seguir forte para a conclusão desta pesquisa.

À minha mãe e às minhas irmãs, nas quais me inspiro por suas histórias de vida e determinação; por serem minha fortaleza; por participarem de todos os passos da minha caminhada e por todos os momentos em que nos encontramos, os quais são divertidos e aconchegantes.

Ao meu esposo, por ser o meu porto seguro; por participar de muitos momentos da minha vida, desde os piores aos melhores; por ser o meu braço direito sempre que eu preciso; pelo companheirismo e apoio nas realizações dos meus sonhos; e por compreender alguns momentos de ausência durante a escrita deste trabalho.

À minha querida orientadora, professora doutora Cordelia, que me acompanha desde a graduação; por ser um exemplo de competência, sabedoria e paciência; por me dar segurança a cada orientação; por ser muito mais que uma orientadora, mas uma amiga; e por ser fundamental na realização deste sonho, o meu tão esperado Mestrado.

Aos professores do Programa de Pós-Graduação em Linguística (PPGL) da Universidade de Brasília, pelos seus ensinamentos; em especial aos professores da banca; e ao professor doutor Guilherme Rios, que também participou da minha banca de qualificação e que me proporcionou muitos ensinamentos, livros emprestados e sugestões indispensáveis para a minha pesquisa.

Aos amigos e colegas de caminhada e de discussões linguísticas, com os quais partilhei angústias, descobertas e ensinamentos: Rodrigo Camilo, Milena Fernandes, Christiane Tegethoff, Thais Lobo, Bárbara Venturoso, Juliana Vassoler, Juliana Ribeiro, 
Letícia Leal, Romar Souza, João Victor Pacífico e outros que estiveram presentes em disciplinas cursadas e congressos.

Ao meu cunhado e amigo, Joel Bento, pela presteza e ajuda com detalhes de formatação.

Aos meus amigos, familiares, compadres e comadres, por todos os momentos de descontração, de amor e de desabafos.

Aos meus sobrinhos e afilhados amados, por serem alegria e amor em minha vida e por compreenderem alguns momentos de ausência durante a realização deste trabalho.

À direção da escola em que trabalho, por seu profissionalismo e pelos esclarecimentos quanto à legislação que apoia a qualificação profissional.

Aos meus alunos, por me permitirem um aprendizado diário e por me instigarem a querer aprender sempre mais. 


\section{RESUMO}

Esta pesquisa tem o objetivo de analisar questões das provas de Língua Portuguesa do Enem à luz das teorias de Multiletramentos e de Multimodalidade para verificar a ocorrência de textos multimodais e as habilidades de leitura que são requeridas para a compreensão desses textos. Para alcançar os resultados, a análise é fundamentada pelas teorias da Análise de Discurso Crítica (ADC) - Chouliaraki \& Fairclough (1999) e Fairclough $(2001 ; 2003)$ - ao investigar os tipos de texto multimodal que estão presentes nas questões das provas de Língua Portuguesa do Enem; pelas teorias da Multimodalidade - Kress \& van Leeuwen (2001) e Vieira $(2007 ; 2010)$ - e da Gramática de Design Visual - Kress \& van Leeuwen (2006) - ao examinar como os textos multimodais são utilizados nas questões do Enem; e por meio das teorias de Multiletramentos - Cope \& Kalantzis (2000) e Rojo \& Moura (2012) - ao averiguar como os multiletramentos são abordados nas questões. O corpus deste trabalho é composto por oito questões, com textos motivadores multimodais, retiradas do caderno de prova Linguagens, Códigos e suas Tecnologias: as questões selecionadas representam os oito anos (de 2009 a 2016), uma questão de cada ano, desde a primeira reformulação e reorganização das provas do Enem. Nesta pesquisa, abordo a metodologia qualitativa com aspectos baseados em Bauer e Gaskell (2000), Denzin (2006) e Flick (2013). Os resultados obtidos demonstram que os significados textuais são compostos pelas modalidades verbal e não verbal, que se complementam para dar sentido aos textos motivadores. A composição textual dos textos motivadores requer do leitor uma experiência multiletrada, pois se trata de textos diversos como panfletos, cartazes, tirinhas, infográficos, etc. Por isso, é necessário que os estudantes utilizem sua experiência como leitor com conhecimentos linguísticos e extralinguísticos adquiridos ao longo de sua vida escolar e extraescolar.

Palavras-chave: Análise de Discurso Crítica; Multiletramentos; Multimodalidade; Enem; Composição Textual. 


\begin{abstract}
This research has the objective of analyzing questions of the Portuguese Language tests of the Enem based on the theories of Multiliteracies and of Multimodality to verify the occurrence of multimodal texts and the reading abilities that are required for the understanding of these texts. To achieve the results, the analysis is based on theories of Critical Discourse Analysis (CDA) - Chouliaraki \& Fairclough (1999) and Fairclough (2001; 2003) by investigating the types of multimodal text that are present in the questions of the Portuguese Language tests of the Enem; on the theories of Multimodality - Kress \& van Leeuwen (2001) and Vieira (2007; 2010) - and the Grammar of Visual Design - Kress \& van Leeuwen (2006) when examining how multimodal texts are used in the Enem tests; and through the theories of Multiliteracies - Cope \& Kalantzis (2000) and Rojo \& Moura (2012) when figuring out how the multiliteracies are approached in the issues. The corpus of this paper is composed of eight questions with multimodal motivator texts taken from the test book Languages, Codes and their Technologies, the selected questions represent the eight years (from 2009 to 2016), a question of each year, from the first reformulation and reorganization of the Enem tests. In this research, I approach the qualitative methodology with aspects based on Bauer and Gaskell (2000), Denzin (2006) and Flick (2013). The results show that the textual meanings are composed of verbal and nonverbal modalities, which complement each other to give meaning to the motivator texts. The textual composition of the motivation texts requires the reader to have a multiliterate experience, because they are diverse texts such as pamphlets, posters, comic strips, infographics, etc. Therefore, it is necessary that students use their experience as a reader with linguistic and extralinguistic knowledge acquired throughout their school and out-of-school life.
\end{abstract}

Keywords: Critical Discourse Analysis; Multiliteracies; Multimodality; Enem; Textual Composition. 


\section{LISTA DE FIGURAS}

Figura 1: Concepção Tridimensional do Discurso... .29

Figura 2: Diagrama dos Multiletramentos proposto pelo Grupo de Nova

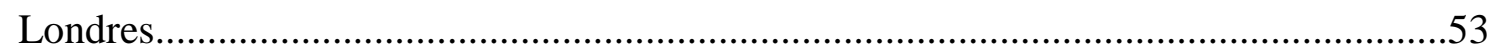

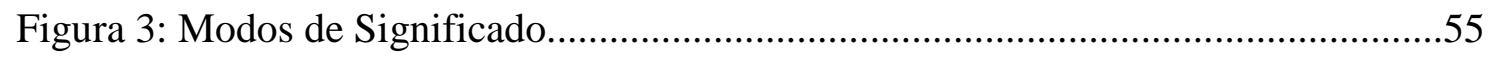

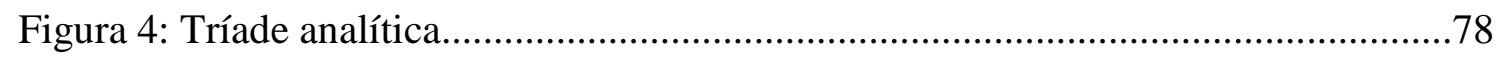

Figura 5: O enfoque da sintaxe visual na proposta da Semiótica Social........................79

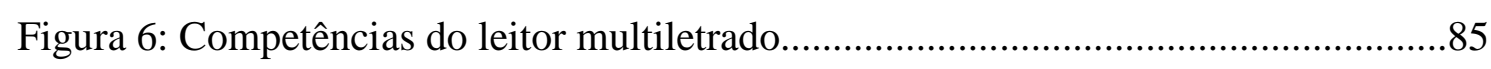

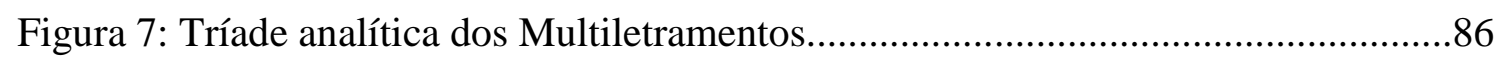

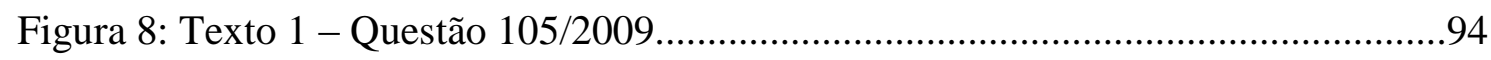

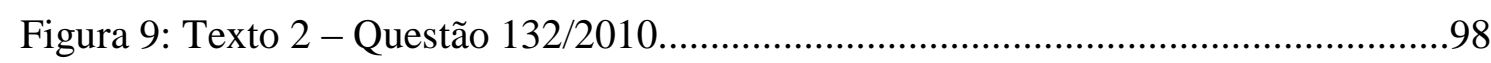

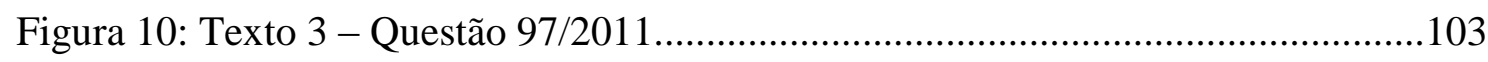

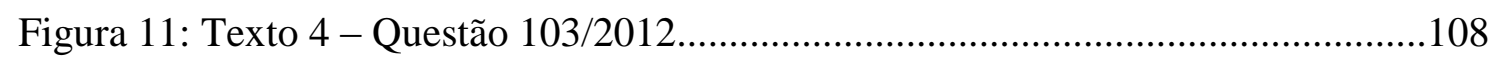

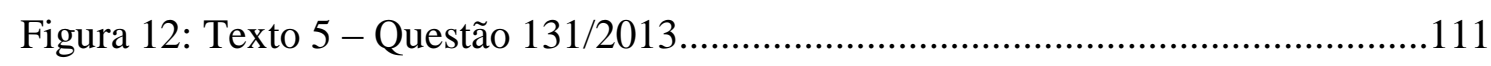

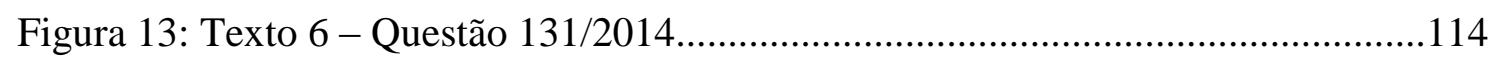

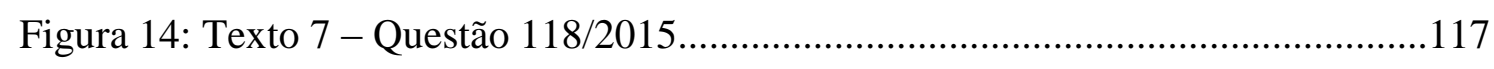

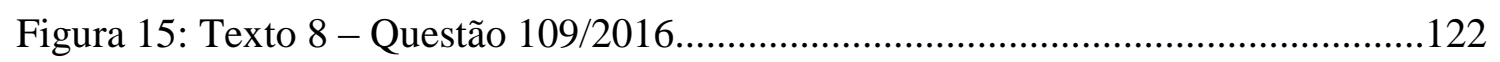




\section{LISTA DE QUADROS}

Quadro 1 - Quadro comparativo entre os objetivos do Enem......................................24

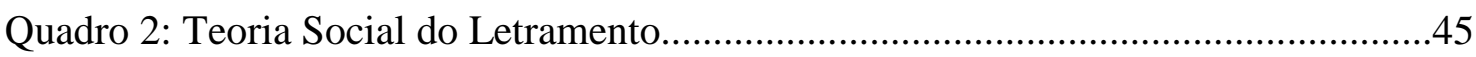

Quadro 3: Quadro comparativo entre as abordagens de pesquisa................................72

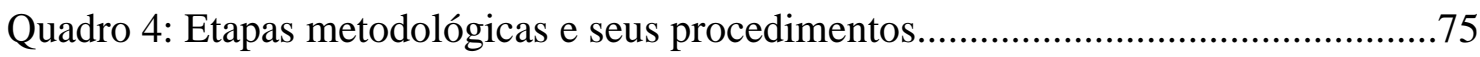

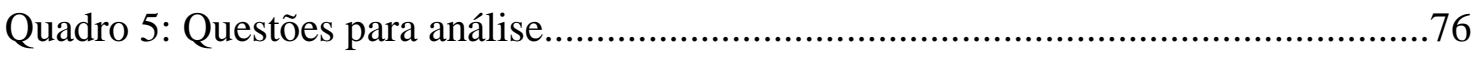

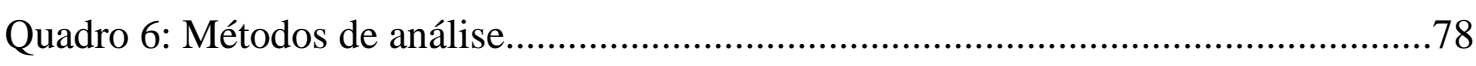

Quadro 7: Categorias da Gramática do Design Visual............................................... 81

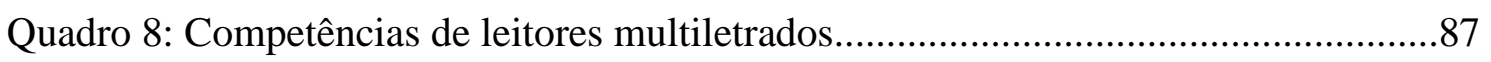

Quadro 9: Caderno de Linguagens, Códigos e suas Tecnologias..................................91

Quadro 10: Categorias de análise dos Multiletramentos............................................93

Quadro 11: Categorias de análise da Gramática do Design Visual................................93 


\section{SUMÁRIO}

A INSPIRAÇÃO INICIAL............................................................................................13

1. CONTEXTUALIZAÇÃO DO ENEM: SUA HISTÓRIA E ORGANIZAÇÃO..17

1.1 A primeira reformulação do Enem................................................................19

1.2 A segunda reformulação do Enem................................................................25

2. OS CAMINHOS TEÓRICOS: PROPOSTAS MULTILETRADAS E MULTIMODAIS...............................................................................................................28

2.1 Perspectivas do Analista de Discurso Crítico sobre Texto e Discurso..............................................................................................................28

2.1.1 Multiletramentos e Multimodalidade como Produtos de Mudança

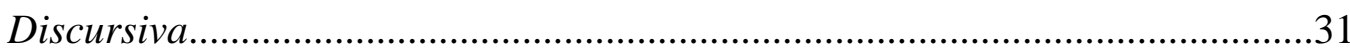

2.2 Duas Vertentes do Letramento: Cognitivo e Sociocultural.........................32

2.2.1 Letramento como Instrumento de Compreensão..........................................36

2.2.2 Letramento na Prática Social.......................................................................40

2.3 Multimodalidade Textual na Contemporaneidade........................................46

2.3.1 Multiletramentos e Multimodalidade: uma prática social multissemiótica.................................................................................................

2.3.1.1 Multiletramentos e Multimodalidade no Ensino........................................59

2.3.2 Habilidades de Leitura para Textos Multimodais.......................................64

2.3.2.1 Conhecimentos Extralinguísticos como Auxílio na Compreensão

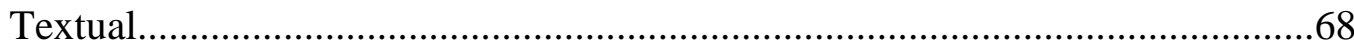

3. CAMINHOS METODOLÓgICOS PARA UMA ANÁLISE MULTISSEMIÓTICA E MULTILETRADA............................................................70

3.1 Duas Vertentes de Pesquisa: Qualitativa versus Quantitativa....................70

3.1.1 A Pesquisa Qualitativa na Pesquisa de Cunho Social...............................73

3.1.2 As Etapas da Pesquisa ...........................................................................

3.2 Contexto da Pesquisa.............................................................................................76

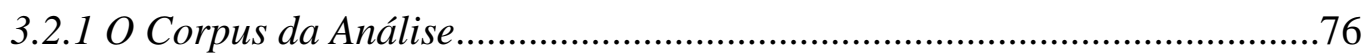

3.3 As Categorias Analíticas....................................................................................77

3.3.1 Categorias da Gramática do Design Visual...............................................79

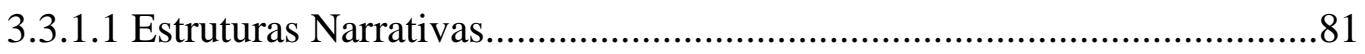

3.3.1.2 A Composição do Significado no Espaço...................................................83 


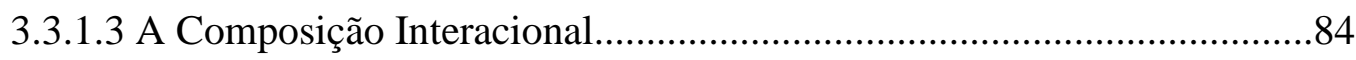

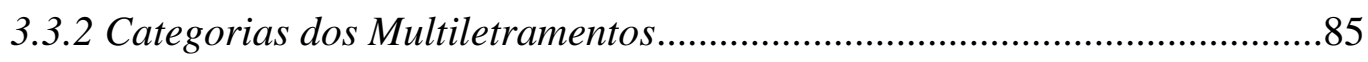

4. ANÁlise dOS DADOS: A COMPOSIÇÃO MULTISSEMIÓTICA E SUAS RELAÇÕES COM OS MULTILETRAMENTOS.....................................................90

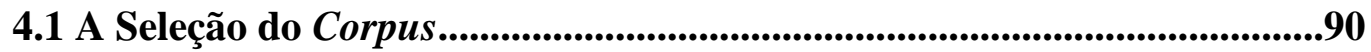

4.2 Alguns Pontos Norteadores para a Análise...............................................92

4.3 Análise de Questões Multimodais de Provas do Enem................................92

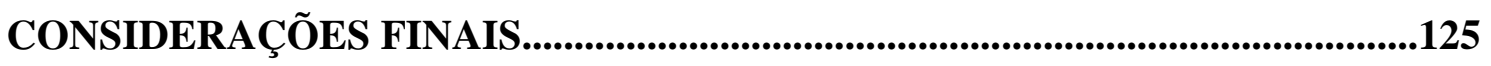

REFERÊNCIAS............................................................................................................129 


\section{MULTILETRAMENTOS E MULTIMODALIDADE NAS PROVAS DO ENEM: MUITO ALÉM DO TEXTO VERBAL}

\section{A INSPIRAÇÃO INICIAL}

Esta dissertação de mestrado analisa questões de Língua Portuguesa (LP) nas provas de Linguagens, Códigos e suas Tecnologias do Exame Nacional do Ensino Médio (Enem), bem como os multiletramentos que subjazem a elas para evidenciar como os textos e esses conceitos se complementam no processo de compreensão textual.

A pesquisa insere-se no projeto "Texto: leitura, compreensão, produção e avaliação" desenvolvido pela Professora Doutora F. Cordelia Oliveira da Silva junto ao Programa de Pós-Graduação em Linguística (PPGL) da Universidade de Brasília e ao Grupo de Pesquisa Língua, Discurso e Representação (Gedis).

O tema surgiu inicialmente do meu interesse como professora e graduada por meio de bolsa de estudo, em decorrência de aprovação na prova do Enem de 2006. Esse exame sempre me despertou curiosidade por sua ampla concorrência, pela popularidade e pela grande proporção de crescimento no contexto atual, pois milhares de alunos se preparam arduamente para as provas que proporcionam ingresso em diversas universidades públicas e faculdades particulares.

Na escola pública, como professora de Línguas Portuguesa e Inglesa, sempre observei o turbilhão de textos presentes nesse exame; com eles, surgem "novas" modalidades; novas porque, muitas vezes, os alunos não as compreendem completamente, pelo pouco convívio ou por não estarem habituados a textos multimodais. Em avaliações escolares, sempre percebi a dificuldade desses alunos com o entendimento de questões que abrangem texto que exijam conhecimentos extralinguísticos, inclusive na interpretação de charges e de outros textos que conjugam linguagem verbal e não verbal.

Sobre os multiletramentos, de forma geral, ainda no mesmo contexto, percebo sua introdução na rotina dos alunos, pois, mesmo que a maioria deles não tenha acesso à internet ou a leituras mais complexas em suas residências, tem contato com televisão, rádios e celulares. Mesmo com o pouco acesso à mídia digital em casa, o que pode privá-los do contato com uma parte da leitura multiletrada; na escola, muitos deles têm a oportunidade de acessar a internet e de utilizar a biblioteca, que pode oferecer opções 
de pesquisas online e leitura de revistas, jornais impressos, panfletos de propaganda, livros, etc.

Com o passar dos anos, após eu ter ingressado em um centro universitário pela aprovação no Enem e finalizado minha graduação em Letras (Português e Inglês), passei a acompanhar cada vez mais de perto a evolução do exame. Assim, com a experiência docente, senti necessidade de pesquisar sobre Multiletramentos e Multimodalidade para analisar a compreensão de questões das provas de Língua Portuguesa. Como o exame é organizado por área de conhecimento, optei por analisar questões de um dos cadernos, "Linguagens, Códigos e suas Tecnologias", buscando aquelas que não requeiram conhecimentos específicos de outras disciplinas que não seja a Língua Portuguesa.

Como pesquisadora, a escolha do tema surgiu do interesse de analisar os multiletramentos subjacentes às questões do Enem, bem como a multimodalidade como elemento da construção de sentidos e como instrumento de compreensão. $\mathrm{Na}$ perspectiva científica, acadêmica e social, as considerações aqui apresentadas contribuirão para esclarecimentos quanto às práticas de multiletramentos e à compreensão de textos multimodais, buscando analisar quais as modalidades dos textos estão presentes nas questões de LP do Enem, um exame reconhecido socialmente e hoje, talvez, mais importante que o vestibular.

A partir da minha experiência pessoal com o Enem e da observação atenta às provas aplicadas, é possível indagar quão grande tem se tornado a proporção dessa avaliação, a evolução da linguagem nas questões e a exigência de textos atuais e multimodais. Essas são, portanto, minhas motivações para empreender este trabalho acadêmico.

Parto ainda do princípio de que, com as inovações nos conceitos e com o surgimento de novos padrões de textos e de novas tecnologias, é importante desenvolver, no contexto escolar, práticas de multiletramentos que incluam meios e textos diversos e atualizados. Nesse cenário, hoje, convivemos com mais textos multimodais e, devido à presença deles, é necessário investir na formação de leitores capazes de compreendê-los e às suas multissemioses; ou seja, leitores que interpretem e compreendam o(s) sentido(s) proposto(s) por eles.

Considerando as mudanças de paradigma relativas aos textos produzidos em nosso momento social e a emergência do Enem como avaliação nacionalmente aplicada 
aos concluintes do Ensino Médio (EM), o exame tornou-se um processo avaliativo que precisa ser analisado e estudado para que as habilidades nele avaliadas possam ser devidamente (re)conhecidas por todos os atores envolvidos no processo. Então, é necessário refletir sobre como os textos multimodais são apresentados nas questões de LP e que habilidades de leitura são exigidas dos alunos.

Para isso, o objetivo geral deste trabalho é analisar questões das provas de LP do Enem à luz das teorias de Multiletramentos e de Multimodalidade para verificar a ocorrência de textos multimodais e as habilidades de leitura que são requeridas para a compreensão desses textos.

Alguns objetivos específicos deste trabalho são:

1) Analisar os tipos de texto multimodal presentes nas questões das provas de LP do Enem, considerando os conceitos de textos trazidos pela Análise de Discurso Crítica (ADC) - Chouliaraki \& Fairclough (1999) e Fairclough (2001; 2003);

2) Analisar como os textos multimodais são utilizados nas questões de LP do Enem, a partir das teorias da Multimodalidade - Kress \& van Leeuwen (2001) e Vieira (2007; 2010) - e da Gramática de Design Visual - Kress \& van Leeuwen (2006);

3) Analisar como os multiletramentos são abordados nas questões analisadas por meio das teorias de Multiletramentos - Cope \& Kalantzis (2000) e Rojo e Moura (2012).

Esta dissertação está organizada em introdução, quatro capítulos e considerações finais. O primeiro capítulo apresenta uma contextualização histórica do Enem, abrangendo as visões legal e social do exame; também apresenta a matriz de habilidades de Linguagens, Códigos e suas Tecnologias (LCT) e discorre sobre algumas diferenças entre o modelo antigo do Enem, até o ano de 2008, o modelo atual, instituído a partir de 2009, e outras alterações no exame no ano de 2017.

O segundo capítulo traz à baila a fundamentação das teorias utilizadas nesta pesquisa - ADC, Letramentos, Multiletramentos e Multimodalidade, sob a visão de autores como Chouliaraki \& Fairclough (1999); Fairclough (2001 [1992]; 2003); Barton (1994); Street (1994); Rios (2010); Kleiman (2005, 2014); Soares (2004); Kress \& van Leeuwen (2001; 2006 [1996]); Vieira (2007; 2010); Cope \& Kalantzis (2000); e Rojo e Moura (2012). 
O terceiro capítulo apresenta a metodologia utilizada, fundamentalmente a pesquisa qualitativa e teórico-conceitual, realizadas para conceituações e levantamento de dados para análise. Esse capítulo discorre também sobre o levantamento de dados dos textos multimodais encontrados nas questões das provas dos cadernos de LCT do Enem e sobre os critérios utilizados para as análises das questões.

O quarto capítulo expõe a análise das questões de provas do Enem, as edições de 2009 a 2016; mostra alguns textos utilizados nas questões, apresenta a análise de textos multimodais por meio das teorias da Multimodalidade - de Kress \& van Leeuwen (2001) e Vieira (2007; 2010) - e da Gramática do Design Visual de Kress \& van Leeuwen (1996), e destaca os multiletramentos que perpassam as questões analisadas por meio das teorias de Multiletramentos de Cope \& Kalantzis (2000).

As considerações finais discorrem sobre a discussão dos resultados das análises e as reflexões sobre as teorias utilizadas nos textos analisados, mostrando como os multiletramentos e a multimodalidade se complementam para a compreensão do corpus. 


\section{CONTEXTUALIZAÇÃO DO ENEM: SUA HISTÓRIA E ORGANIZAÇÃO}

O Exame Nacional do Ensino Médio (Enem) foi criado em 1998 pelo Ministério da Educação (MEC). Quando foi criado, foi considerado uma inovação, pois era um exame unificado aplicado em todo o país. A prova possuía 63 questões objetivas e uma prova discursiva, e tinha o intuito de avaliar o aprendizado dos alunos ao final do Ensino Médio (EM) e essa etapa da Educação Básica em todo o Brasil. A Portaria MEC $\mathrm{n}^{\circ} 438$, de 28 de maio de 1998, apresentou seus objetivos iniciais:

\footnotetext{
Artigo $1^{\circ}$ - Instituir o Exame Nacional do Ensino Médio - ENEM, como procedimento de avaliação do desempenho do aluno, tendo por objetivos:

I - conferir ao cidadão parâmetro para autoavaliação, com vistas à continuidade de sua formação e à sua inserção no mercado de trabalho;

II - criar referência nacional para os egressos de qualquer das modalidades do ensino médio;

III - fornecer subsídios às diferentes modalidades de acesso à educação superior;

IV - constituir-se em modalidade de acesso a cursos profissionalizantes pós-médio.
}

A mesma Portaria indicava que "O planejamento e a operacionalização do ENEM são de competência do Instituto Nacional de Estudos e Pesquisas Educacionais INEP", além disso, o Inep deveria "[...] coordenar os trabalhos de normatização, supervisionar as ações de implementação, assim como promover a avaliação contínua do processo [...]".

As questões da prova foram organizadas, inicialmente, a partir de competências e habilidades, que foram publicadas no Artigo $2^{\circ}$ da Portaria MEC $n^{\circ} 438$, de 28 de maio de 1998. Devido ao foco da análise aqui desenvolvida, apresentarei apenas as competências e habilidades relativas à Matriz de Linguagens, Códigos e suas Tecnologias que se refiram à Língua Portuguesa e áreas afins:

$\S 1^{\circ}$ - São as seguintes competências a serem avaliadas:

I - dominar a norma culta da Língua Portuguesa e fazer uso das linguagens matemática, artística e científica;

III - selecionar, organizar, relacionar, interpretar dados e informações representados de diferentes formas, para tomar decisões e enfrentar situações-problema; 
IV - relacionar informações, representadas em diferentes formas, e conhecimentos disponíveis em situações concretas, para construir argumentação consistente;

$\S 2^{\circ}$ - São as seguintes habilidades a serem avaliadas:

I - dada a descrição discursiva ou por ilustração de um experimento ou fenômeno de natureza científica, tecnológica ou social, identificar variáveis relevantes e selecionar os instrumentos necessários para realização ou interpretação do mesmo;

IV - dada uma situação-problema, apresentada em uma linguagem de determinada área de conhecimento, relacioná-la com sua formulação em outras linguagens ou vice-versa;

$\mathrm{V}$ - a partir da leitura de textos literários consagrados e de informações sobre concepções artísticas, estabelecer relações entre eles e seu contexto histórico, social, político ou cultural, inferindo as escolhas dos temas, gêneros discursivos e recursos expressivos dos autores;

VI - com base em um texto, analisar as funções da linguagem, identificar marcas de variantes linguísticas de natureza sociocultural, regional, de registro ou de estilo, e explorar as relações entre as linguagens coloquial e formal;

XII - analisar fatores socioeconômicos e ambientais associados ao desenvolvimento, às condições de vida e saúde de populações humanas, por meio da interpretação de diferentes indicadores;

XVIII - valorizar a diversidade dos patrimônios etnoculturais e artísticos, identificando-a em suas manifestações e representações em diferentes sociedades, épocas e lugares;

As habilidades do Enem foram organizadas de forma que se esperava que os alunos, ao final do Ensino Médio, possuíssem essas habilidades e estivessem aptos a desenvolvê-las nas questões da prova.

No início ${ }^{1}$, o Enem não era muito popular e não tinha muitos inscritos - quando comparamos o crescimento do número de inscrições ao longo dos anos. Esse fato pode ser explicado pela não obrigatoriedade do exame e/ou por muitos não o conhecerem ainda; assim, a primeira edição, em 1998, obteve aproximadamente 157 mil inscritos. Em 2004, quando o MEC instituiu o Programa Universidade para Todos (ProUni), o qual possibilita concessão de bolsas de estudo a partir da nota obtida no Enem, o exame começou a ganhar mais importância e, assim, mais popularidade e concorrência; nesse ano, ele recebeu aproximadamente 1,5 milhão de inscrições.

1 As informações sobre a história do Enem foram retiradas do site: http://portal.mec.gov.br/component/content/article?id=30781 (acessado em 21 de maio de 2017). 


\subsection{A primeira reformulação do Enem}

Com 10 anos de existência, em 2008, o MEC decidiu reformular o exame, reorganizando-o por meio de matrizes de referências e inserindo mais um objetivo: o ingresso em Universidades Públicas, o que passou a ter validade a partir do ano de 2009. Para direcionar os candidatos e organizar as provas, foram criados cinco eixos cognitivos comuns a todas as áreas de conhecimento e eles estão no Anexo III da Portaria $\mathrm{n}^{\circ} 109$, de 27 de maio de 2009:

I - Dominar linguagens (DL): dominar a norma culta da Língua Portuguesa e fazer uso das linguagens matemática, artística e científica e das línguas espanhola e inglesa.

II - Compreender fenômenos (CF): construir e aplicar conceitos das várias áreas do conhecimento para a compreensão de fenômenos naturais, de processos histórico-geográficos, da produção tecnológica e das manifestações artísticas.

III - Enfrentar situações-problema (SP): selecionar, organizar, relacionar, interpretar dados e informações representados de diferentes formas, para tomar decisões e enfrentar situações-problema.

IV - Construir argumentação (CA): relacionar informações, representadas em diferentes formas, e conhecimentos disponíveis em situações concretas, para construir argumentação consistente.

$\mathrm{V}$ - Elaborar propostas (EP): recorrer aos conhecimentos desenvolvidos na escola para elaboração de propostas de intervenção solidária na realidade, respeitando os valores humanos e considerando a diversidade sociocultural.

A proposta de implantação desses eixos cognitivos possibilitou uma prova menos "conteudista" e mais crítica e interdisciplinar, permitiu que fossem requeridas maiores habilidades de interpretação e de autonomia para responder às questões.

As matrizes de referência criadas no ano de 2009 indicam habilidades para orientar e avaliar os itens da prova. Elas foram divididas em quatro áreas de conhecimento $^{2}$ :

- Linguagens, códigos e suas tecnologias, que abrange o conteúdo de Língua Portuguesa (Gramática e Interpretação de Texto), Língua Estrangeira Moderna, Literatura, Artes, Educação Física e Tecnologias da Informação.

- Matemática e suas tecnologias.

\footnotetext{
${ }^{2}$ Informações retiradas do site do Inep: http://portal.inep.gov.br/matriz-de-referencia (acessado em 27 de março de 2017).
} 
- Ciências da Natureza e suas tecnologias, que abrange os conteúdos de Química, Física e Biologia.

- Ciências Humanas e suas tecnologias, que abrange os conteúdos de Geografia, História, Filosofia e Sociologia.

Para cada matriz de referência, competências e habilidades diversas foram criadas para nortear a elaboração de cada prova. Como a atenção deste trabalho é voltada para a matriz Linguagens, Códigos e suas Tecnologias, com foco evidente em questões de LP, abaixo encontram-se as competências e habilidades que abrangem essa área:

Competência de área 1 - Aplicar as tecnologias da comunicação e da informação na escola, no trabalho e em outros contextos relevantes para sua vida.

H1 - Identificar as diferentes linguagens e seus recursos expressivos como elementos de caracterização dos sistemas de comunicação.

H2 - Recorrer aos conhecimentos sobre as linguagens dos sistemas de comunicação e informação para resolver problemas sociais.

H3 - Relacionar informações geradas nos sistemas de comunicação e informação, considerando a função social desses sistemas.

H4 - Reconhecer posições críticas aos usos sociais que são feitos das linguagens e dos sistemas de comunicação e informação. [...]

Competência de área 5 - Analisar, interpretar e aplicar recursos expressivos das linguagens, relacionando textos com seus contextos, mediante a natureza, função, organização, estrutura das manifestações, de acordo com as condições de produção e recepção.

H15 - Estabelecer relações entre o texto literário e o momento de sua produção, situando aspectos do contexto histórico, social e político.

H16 - Relacionar informações sobre concepções artísticas e procedimentos de construção do texto literário.

H17 - Reconhecer a presença de valores sociais e humanos atualizáveis e permanentes no patrimônio literário nacional.

Competência de área 6 - Compreender e usar os sistemas simbólicos das diferentes linguagens como meios de organização cognitiva da realidade pela constituição de significados, expressão, comunicação e informação.

H18 - Identificar os elementos que concorrem para a progressão temática e para a organização e estruturação de textos de diferentes gêneros e tipos.

H19 - Analisar a função da linguagem predominante nos textos em situações específicas de interlocução.

H20 - Reconhecer a importância do patrimônio linguístico para a preservação da memória e da identidade nacional. 
Competência de área 7 - Confrontar opiniões e pontos de vista sobre as diferentes linguagens e suas manifestações específicas.

H21 - Reconhecer em textos de diferentes gêneros, recursos verbais e não-verbais utilizados com a finalidade de criar e mudar comportamentos e hábitos.

H22 - Relacionar, em diferentes textos, opiniões, temas, assuntos e recursos linguísticos.

H23 - Inferir em um texto quais são os objetivos de seu produtor e quem é seu público alvo, pela análise dos procedimentos argumentativos utilizados.

H24 - Reconhecer no texto estratégias argumentativas empregadas para o convencimento do público, tais como a intimidação, sedução, comoção, chantagem, entre outras.

Competência de área 8 - Compreender e usar a língua portuguesa como língua materna, geradora de significação e integradora da organização do mundo e da própria identidade.

H25 - Identificar, em textos de diferentes gêneros, as marcas linguísticas que singularizam as variedades linguísticas sociais, regionais e de registro.

H26 - Relacionar as variedades linguísticas a situações específicas de uso social.

H27 - Reconhecer os usos da norma padrão da língua portuguesa nas diferentes situações de comunicação.

Competência de área 9 - Entender os princípios, a natureza, a função e o impacto das tecnologias da comunicação e da informação na sua vida pessoal e social, no desenvolvimento do conhecimento, associando-o aos conhecimentos científicos, às linguagens que lhes dão suporte, às demais tecnologias, aos processos de produção e aos problemas que se propõem solucionar.

H28 - Reconhecer a função e o impacto social das diferentes tecnologias da comunicação e informação.

H29 - Identificar pela análise de suas linguagens, as tecnologias da comunicação e informação.

H30 - Relacionar as tecnologias de comunicação e informação ao desenvolvimento das sociedades e ao conhecimento que elas produzem.

As competências pressupõem os requisitos necessários que os candidatos devem possuir para compreender e realizar as provas; enquanto as habilidades são avaliadas na elaboração das questões.

A competência de área 1 (C1) requer que o estudante esteja apto a empregar as tecnologias da informação em diversos textos e contextos; quanto à competência de área 5 (C5), ela direciona-se diretamente às linguagens, por requisitar interpretação e análise de textos de acordo com seus contextos; logo a C6 envolve a compreensão e o uso de diferentes linguagens, organizadas cognitivamente por meio de significados; a C7 
confronta opiniões e pontos de vista sobre diferentes linguagens e seus contextos; enquanto a C8 refere-se à compreensão e ao uso da língua como materna, levando em consideração questões como significado e identidade; a última que reconheço em relação à linguagem e áreas afins é a C9, que exige o entendimento princípios ligados ao impacto das tecnologias na vida pessoal e social e no desenvolvimento de conhecimentos científicos e solucionadores de problemas. Essas competências incitam leitores e estudantes críticos, para que tenham posicionamento crítico sobre o que leem nas questões do Enem; para que os candidatos considerem os textos com seus aspectos culturais e sociais; para que levem em consideração muito mais que conteúdos e nomenclaturas, mas textos em diversos contextos, o que requer importar-se com o momento social em que ele foi produzido e a que ele se refere.

Com a primeira reformulação, o exame passou de 63 para 180 questões objetivas, e uma prova discursiva, que permaneceu. Por isso, em vez de ser aplicado em um único domingo, passou a ser feito em dois dias consecutivos, sábado e domingo. No primeiro dia, aplicavam-se 90 questões: 45 da matriz de Ciências da Natureza e suas Tecnologias, e 45 da de Ciências Humanas e suas Tecnologias; e, no segundo dia, 90 questões: 45 da matriz de Linguagens, Códigos e suas Tecnologias, e 45 da de Matemática e suas Tecnologias, e a prova de redação.

A partir da edição de 2009, o MEC inseriu a possibilidade de certificação do Ensino Médio aos candidatos fora da faixa etária dessa etapa do ensino; além disso, ele passou a oferecer as seguintes oportunidades:

- Sistema de Seleção Unificada (SiSU) - possibilita a concorrência de inúmeras vagas em universidades públicas de várias regiões do Brasil.

- Programa Universidade para Todos (Prouni) - proporciona bolsas de estudo a estudantes de baixa renda nas universidades ou faculdades particulares.

- Fundo de Financiamento Estudantil (Fies) - possibilita, aos alunos que fizeram o Enem e que têm condições de pagar, financiamento de até $100 \%$ das mensalidades de faculdade particular para pagamento após o término do curso.

- Certificação do Ensino Médio - para estudantes maiores de 18 anos que não concluíram o Ensino Médio na faixa etária. Eles podem receber o diploma do Ensino Médio se obtiverem uma pontuação mínima no exame. 
O que regulamentou e explicou as mudanças da prova foi a Portaria $\mathrm{n}^{\circ} 109$, de 27 de maio de 2009, nela constam os novos objetivos do Enem:

\section{Dos Objetivos}

Art. $2^{\circ}$ Constituem objetivos do Enem:

I - oferecer uma referência para que cada cidadão possa proceder à sua auto-avaliação com vistas às suas escolhas futuras, tanto em relação ao mundo do trabalho quanto em relação à continuidade de estudos;

II - estruturar uma avaliação ao final da educação básica que sirva como modalidade alternativa ou complementar aos processos de seleção nos diferentes setores do mundo do trabalho;

III - estruturar uma avaliação ao final da educação básica que sirva como modalidade alternativa ou complementar aos exames de acesso aos cursos profissionalizantes, pós-médios e à Educação Superior;

IV - possibilitar a participação e criar condições de acesso a programas governamentais;

V - promover a certificação de jovens e adultos no nível de conclusão do ensino médio nos termos do artigo $38, \S \S 1^{\circ}$ e $2^{\circ}$ da Lei $n^{\circ} 9.394 / 96$

- Lei das Diretrizes e Bases da Educação Nacional

(LDB);

VI - promover avaliação do desempenho acadêmico das escolas de ensino médio, de forma que cada unidade escolar receba o resultado global;

VII - promover avaliação do desempenho acadêmico dos estudantes ingressantes nas Instituições de Educação Superior;

Esses novos objetivos proporcionam mais oportunidades aos candidatos que realizam o Enem, pois possibilita o ingresso não só mais em cursos profissionalizantes, por exemplo, mas também na Educação Superior, além de permitir a avaliação individual do candidato e ainda de sua escola; outra inovação foi a possibilidade de certificação no Ensino Médio para estudantes que não concluíram o EM dentro da faixa etária esperada. Para contrapor os antigos objetivos do Enem (de 1998) e os novos (de 2009), apresento a seguir um quadro comparativo entre eles: 
Quadro 1 - Quadro comparativo entre os objetivos do Enem

\begin{tabular}{|l|l|}
\hline \multicolumn{1}{|c|}{1998} & \multicolumn{1}{c|}{2009} \\
\hline $\begin{array}{l}\text { I - conferir ao cidadão parâmetro para } \\
\text { autoavaliação, com vistas à continuidade de } \\
\text { sua formação e à sua inserção no mercado } \\
\text { de trabalho; }\end{array}$ & $\begin{array}{l}\text { I - oferecer uma referência para que cada } \\
\text { cidadão possa proceder à sua auto-avaliação } \\
\text { com vistas às suas escolhas futuras, tanto } \\
\text { em relação ao mundo do trabalho quanto em } \\
\text { relação à continuidade de estudos; } \\
\text { II - estruturar uma avaliação ao final da } \\
\text { educação básica que sirva como modalidade } \\
\text { alternativa ou complementar aos processos } \\
\text { de seleção nos diferentes setores do mundo } \\
\text { do trabalho; }\end{array}$ \\
\hline $\begin{array}{l}\text { II - criar referência nacional para os } \\
\text { egressos de qualquer das modalidades do } \\
\text { ensino médio; }\end{array}$ & $\begin{array}{l}\text { III - estruturar uma avaliação ao final da } \\
\text { educação básica que sirva como modalidade } \\
\text { alternativa ou complementar aos exames de } \\
\text { acesso aos cursos profissionalizantes, pós- } \\
\text { médios e à Educação Superior; }\end{array}$ \\
\hline $\begin{array}{l}\text { III - fornecer subsídios às diferentes } \\
\text { modalidades de acesso à educação superior; }\end{array}$ & $\begin{array}{l}\text { IV - possibilitar a participação e criar } \\
\text { condições de acesso a programas } \\
\text { governamentais; }\end{array}$ \\
\hline $\begin{array}{l}\text { IV - constituir-se em modalidade de acesso } \\
\text { a cursos profissionalizantes pós-médio. }\end{array}$ & $\begin{array}{l}\text { V promover a certificação de jovens e } \\
\text { adultos no nível de conclusão do ensino } \\
\text { médio nos termos do artigo 38, §§ } 1^{\circ} \text { e } 2^{\circ} \text { da } \\
\text { Lei no 9.394/96 - Lei das Diretrizes e Bases } \\
\text { da Educação Nacional } \\
\text { (LDB); } \\
\text { VI - promover avaliação do desempenho } \\
\text { acadêmico das escolas de ensino médio, de } \\
\text { forma que cada unidade escolar receba o } \\
\text { resultado global; } \\
\text { VII - promover avaliação do desempenho } \\
\text { acadêmico dos estudantes ingressantes nas } \\
\text { Instituições de Educação Superior; }\end{array}$ \\
\hline
\end{tabular}

Fonte: a própria autora com base nos objetivos do Enem.

Em 2009, foram registrados aproximadamente 4,1 milhões de inscritos. Assim, depois da reorganização do Enem, com a inserção dos novos objetivos, ele se tornou mais relevante, o que se evidencia pelo crescimento da adesão e, com isso, ainda mais popular. Aos poucos, outras oportunidades de inserção ao ensino por meio do Enem foram surgindo; em 2012, instituiu-se o Sistema de Seleção Unificada para Cursos Técnicos (Sisutec) - semelhante ao SiSU, mas para cursos técnicos, que oferece inscrições duas vezes ao ano e disponibiliza vagas gratuitas para cursos técnicos e profissionalizantes, em instituições públicas e privadas. 
Em 2013, o programa Ciência sem Fronteiras (programa de bolsas de estudo para cursar um ou dois semestres fora do país, que tinha como critérios de seleção participação no Enem e a obtenção da nota mínima de 600 pontos) foi instituído. Assim, em 2014, houve o recorde de inscrições no Enem, mais de 8,7 milhões. A partir de 2014, o Inep firmou parceria com algumas universidades portuguesas - Coimbra e Algarve, com aproveitamento dos resultados do exame para o ingresso em suas graduações e, em 2017, são aproximadamente 18 instituições portuguesas.

Como muitos candidatos começaram a optar por fazer a prova do Enem em vez da prova do vestibular, algumas universidades foram abrindo mais espaço para esse tipo de seleção: a Universidade de Brasília (UnB), por exemplo, passou a ter uma única edição de vestibular por ano, quando antes tinha duas, e a utilizar as notas do Enem para o ingresso ao Ensino Superior por meio do SiSU.

\subsection{A segunda reformulação do Enem}

Em abril de 2017, o Enem passou por mais uma reorganização. As mudanças atingiram a aplicação e a organização das provas, a divulgação dos resultados e os objetivos. As alterações se resumem nos seguintes tópicos ${ }^{3}$ :

- A certificação do Ensino Médio por meio do Enem não será mais realizada. Ela passa a ser feita pelo Sistema Nacional de Avaliação da Educação Básica (Saeb) por meio do Exame Nacional para Certificação de Competências de Jovens e Adultos (Encceja).

- Os resultados do exame serão divulgados apenas individualmente, e não mais por escola, como era feito nos últimos anos. A justificativa do Inep é que "[...] as provas não são elaboradas com objetivo de medir a qualidade do ensino nas escolas do país".

- As provas serão aplicadas em dois domingos seguidos e, não mais, em um sábado e um domingo consecutivos.

- A configuração das matrizes dos cadernos de questões para cada dia de prova foi alterada: no primeiro dia, 90 questões das áreas de Linguagens, Códigos e suas

\footnotetext{
${ }^{3}$ Informações retiradas de http://www.enem2017.com/mec-oficializou-mudancas-enem-2017.html (acessado em 21 de maio de 2017).
} 
Tecnologias, Ciências Humanas e suas Tecnologias, e a prova de Redação; no segundo, 90 questões de Ciências da Natureza e suas Tecnologias, e Matemática e suas Tecnologias.

- Os candidatos deficientes auditivos poderão solicitar a realização dos exames por meio de videoprovas, em notebooks cedidos pelo Inep, traduzidas em Língua Brasileira de Sinais, além de anteriormente terem acesso também a vídeos com informações sobre o Enem.

Para atender a essa nova configuração, o artigo $3^{\circ}$ da Portaria $n^{\circ} 468$, de 3 de abril de 2017, alterou, mais uma vez, os objetivos do Enem:

Art. $3^{\circ}$ Os resultados do ENEM deverão possibilitar:

I - a constituição de parâmetros para a autoavaliação do participante, com vistas à continuidade de sua formação e a sua inserção no mercado de trabalho;

II - a criação de referência nacional para o aperfeiçoamento dos currículos do ensino médio;

III - a utilização do Exame como mecanismo único, alternativo ou complementar para acesso à educação superior, especialmente a ofertada pelas instituições federais de educação superior;

IV - o acesso a programas governamentais de financiamento ou apoio ao estudante da educação superior;

V - a sua utilização como instrumento de seleção para ingresso nos diferentes setores do mundo do trabalho; e

VI - o desenvolvimento de estudos e indicadores sobre a educação brasileira.

A partir de mais uma revisão nos objetivos do Enem, houve alterações em alguns objetivos do exame que foram retirados: o de certificação do EM para alunos fora da faixa etária e a avaliação acadêmica de escolas do EM; enquanto outros objetivos foram modificados ou inseridos em 2017: referência nacional para aperfeiçoamento dos currículos do EM e utilização do exame para acesso a instituições federais de Educação Superior. Com mais uma reformulação, o Enem ${ }^{4}$ tem em 2017:

[...] o objetivo de avaliar o desempenho do estudante ao fim da educação básica, buscando contribuir para a melhoria da qualidade desse nível de escolaridade [...] ser utilizado também como

${ }^{4}$ Conceitos retirados de http://portal.inep.gov.br/perguntas-frequentes (acessado em 27 de março de 2017). 
mecanismo de seleção para o ingresso no ensino superior. [...] respeitando a autonomia das universidades, a utilização dos resultados do Enem para acesso ao Ensino Superior pode ocorrer como fase única de seleção ou combinado com seus processos seletivos próprios.

Além disso, a partir de 2017, foram disponibilizados os seguintes programas aos candidatos $^{5}$ : Sistema de Seleção Unificada (SiSU); Programa Universidade para Todos (Prouni); Programa Nacional de Acesso ao Ensino Técnico e Emprego (Pronatec); Fundo de Financiamento Estudantil (Fies); e Ingresso em Instituições Portuguesas.

Com o passar dos anos, pela popularidade e pela inserção de diversos programas governamentais, as provas do Enem vêm sendo aperfeiçoadas com a inserção de conhecimentos diversos e organização mais precisa. Mas o que o difere de um exame de vestibular é sua contextualização, seu estímulo ao pensamento e à reflexão e não apenas a consulta de conteúdos. Para comprovar sua popularidade, há dados numéricos sobre a edição do Enem de 2016 retirados do site do Ministério da Educação que confirmam a importância do exame: foram mais de 8,6 milhões de participantes inscritos.

Após esta contextualização histórica e organizacional do meu instrumento de análise, o Enem, observo como o exame se modificou e se atualizou ao longo dos anos de sua existência, e como ele procura adequar-se aos candidatos que o realizam pelas mudanças nas matrizes de referência, pela organização de sua aplicação e de suas questões elaboradas com textos diversos e, até mesmo, pelos programas ofertados aos que se submetem ao exame e obtêm sucesso. Passarei agora para o capítulo teórico, essencial para a continuidade deste trabalho por trazer conceitos, à luz da Análise de Discurso Crítica, sobre o Letramento, a Multimodalidade e os Multiletramentos.

\footnotetext{
${ }^{5}$ Conceitos retirados de http:// www.infoenem.com.br/ tudo-sobre-o-enem-2017/ (acessado em 27 de março de 2017) e aqui estão em forma de paráfrases.
} 


\section{OS CAMINHOS TEÓRICOS: PROPOSTAS MULTILETRADAS E MULTIMODAIS}

Neste capítulo, discorrerei sobre conceitos essenciais para as análises desta pesquisa: Multiletramentos e Multimodalidade, com base em teorias da Análise de Discurso Crítica (ADC). Para embasar o estudo, iniciarei apresentando algumas considerações da ADC sobre o Texto; depois, apontarei duas perspectivas do Letramento, as quais são complementares para explicar a relação de compreensão das questões a serem analisadas no capítulo analítico; e seguirei com definições primordiais sobre a Multimodalidade e os Multiletramentos.

\subsection{Perspectivas do Analista de Discurso Crítico sobre Texto e Discurso}

A Análise de Discurso Crítica (ADC), para Fairclough (2003), está relacionada à transformação social, e contribui para a pesquisa das práticas sociais, em um aspecto mais abstrato, em um nível mais estrutural. O objeto de estudo da ADC é a vida social, as práticas humanas e suas atividades - econômicas, políticas, sociais, etc. Neste trabalho, vou me apropriar de termos e conceitos que estão em constante mudança Multiletramentos e Multimodalidade -, por isso não poderia deixar de trazer as abordagens feitas à luz da ADC sobre definições básicas, como discurso e texto, que estão inseridas como pano de fundo dos conceitos aqui utilizados.

Inicio por um termo essencial na ADC: Discurso. Sobre ele, Fairclough (2001, p. 90) discorre: “Ao usar o termo 'discurso', proponho considerar o uso de linguagem como forma de prática social e não como atividade puramente individual ou reflexo de variáveis situacionais". O autor afirma que o discurso é uma forma de significação de mundo, pois molda a estrutura social e também é moldado por ela dentro de determinados eventos discursivos - em uma aula, em um jantar de família, em uma conversa informal com um amigo, etc. Assim, ele apresenta três funções às quais o discurso está intrinsecamente relacionado: a função relacional - ligada à construção das relações sociais; a função interpessoal - ligada à construção das identidades sociais; e a função ideacional - ligada à construção de sistemas de conhecimento e crenças. 
Fairclough (2001 [1992]) enuncia uma abordagem tridimensional de discurso, composta por Texto, Prática Discursiva e Prática Social. Para explicar melhor a relação entre os termos citados e o discurso, apresento com o esquema abaixo:

Figura 1 - Concepção Tridimensional do Discurso

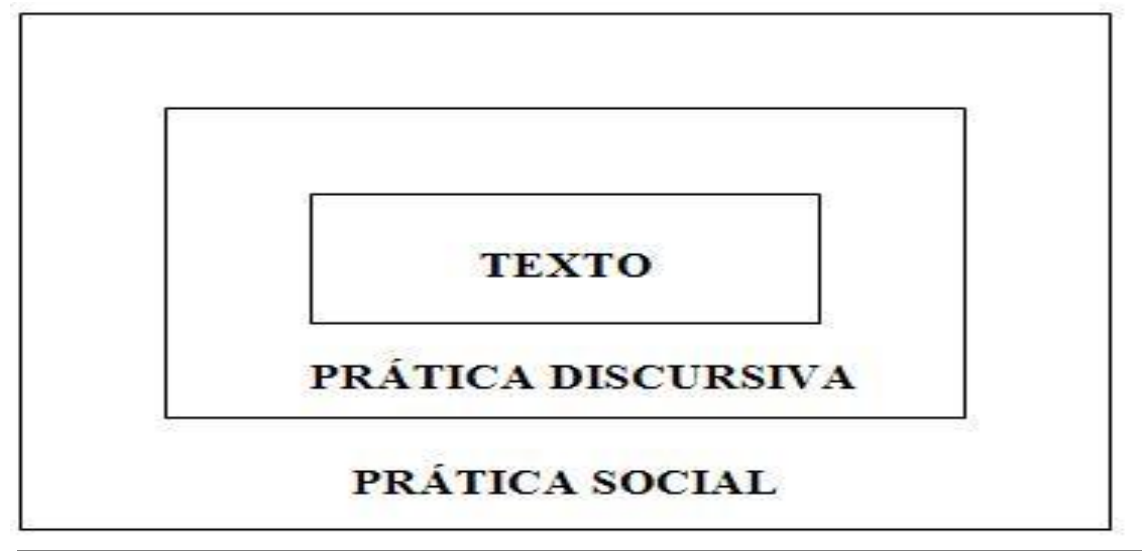

Fonte: Fairclough (2001, p. 101).

Nessa relação tridimensional, um termo complementa o outro, um está dentro do outro, por isso Fairclough (2001, p. 113) afirma que um texto coerente é aquele “[...] cujas partes constituintes são relacionadas com um sentido, de forma que o texto como um todo 'faça sentido', mesmo que haja relativamente poucos marcadores formais". Com relação ao texto, Fairclough (2001) traz a noção de análise organizada em quatro subtópicos:

1. Vocabulário - são palavras individuais, cada indivíduo (re)produz as suas.

2. Gramática - é a organização do vocabulário em frases ou orações.

3. Coesão - são os termos que ligam as frases e orações.

4. Estrutura textual - é a parte macro, a "arquitetura do texto", é a organização do texto em larga escala.

Quanto à prática discursiva, o autor afirma que é o consumo de textos em diferentes formas e em diversos contextos. Ele argumenta que "A prática discursiva manifesta-se em forma linguística, linguagem falada e escrita [...]" (FAIRCLOUGH, 2001, p. 99) e envolve três processos: 
1. Produção - "Ao produzirem seu mundo, as práticas dos membros são moldadas, de forma inconsciente, por estruturas sociais, relações de poder e pela natureza da prática social em que estão envolvidos [...]”. (FAIRCLOUGH, 2001, p. 100)

2. Distribuição - “[...] os textos apresentam resultados variáveis de natureza extradiscursiva, como também discursiva" (FAIRCLOUGH, 2001, p. 108). O autor complementa que alguns textos são escritos, transcritos, reescritos, lidos, relidos, esquecidos, etc.; eles podem representar diversas mensagens em dados contextos, por exemplo, demissão, início de guerra, fim de guerra, declaração de amor, despedida, etc.

3. Consumo - pode ser individual, por exemplo, carta de amor, bilhete informal; ou coletivo, por exemplo, registros administrativos, provas de vestibulares, etc.

O terceiro elemento da concepção tridimensional do discurso é a Prática Social; sobre ela, Fairclough (2001, p. 93) declara que a constituição discursiva da sociedade emana “[...] de uma prática social que está firmemente enraizada em estruturas sociais materiais, concretas, orientando-se para elas". O autor assevera que, assim como o texto, a prática social é uma dimensão do evento discursivo.

Para complementar, Chouliaraki e Fairclough (1999) revelam que toda prática social tem uma dimensão discursiva, assim essas práticas são mediadoras da comunicação. Os pesquisadores afirmam que o discurso na modernidade é extradiscursivamente fundamentado, ou seja, ele é socialmente constitutivo, pois ele é construído de acordo com a posição social em que as pessoas estão. Os autores argumentam também que o termo "discurso" pode se referir aos elementos semióticos das práticas sociais - como fala, escrita, música, etc.; à comunicação não verbal - como expressões faciais, movimentos corporais, gestos, imagens visuais, etc. Considero esses conceitos para o desenvolvimento deste trabalho, por se tratar de análise de textos multimodais e de habilidades de leitura na perspectiva da Pedagogia dos Multiletramentos requeridas dos participantes do exame.

Por fim, em consonância com os autores, ressalto que o discurso está relacionado à formação das identidades constituídas em cada sociedade e às suas práticas sociais. Assim, o discurso é um modo de ação, de representação, de identificação (FAIRCLOUGH, 2001); está diretamente ligado ao Letramento Sociocultural, conceituado posteriormente no item 2.2.2. 


\subsubsection{Multiletramentos e Multimodalidade como produtos de mudança discursiva}

A nossa língua está em constante mudança, retratando práticas sociais atuais, em vista disso, observo as inovações nos textos, como os textos multimodais, que demandam mais atenção e mais habilidades para a compreensão, como será visto adiante. Sobre esse ponto, Fairclough (2001) enuncia que a mudança discursiva tem relação com as mudanças social e cultural, e relação com os eventos discursivos e suas mudanças estruturais, porque ela envolve novas formas de combinação do discurso.

$\mathrm{O}$ autor afirma que os processos sociocognitivos podem contribuir para a mudança discursiva, mas isso depende da natureza da prática social. Fairclough (2001, p. 128) argumenta que "A mudança deixa traços nos textos na forma de coocorrência de elementos contraditórios ou inconsistentes", são eles: mesclas de estilos formais e informais; vocabulários técnicos e não-técnicos; marcadores de autoridade e familiaridade; formas sintáticas mais tipicamente escritas; formas sintáticas mais tipicamente faladas. Conforme Chouliaraki e Fairclough (1999), a mudança nas formas do discurso constitui uma parte das mudanças nas práticas sociais, nas relações entre as práticas sociais e nas mudanças na forma da dialética social.

Neste trabalho, os multiletramentos e a multimodalidade são considerados elementos de mudança discursiva, pois estão sendo inseridos paulatinamente nas práticas sociais. Sobre a ADC e o letramento, Rios (2010a) argumenta que:

Um ponto fundamental derivado dessa integração entre análise do discurso linguisticamente embasada e letramento é o fato de que este está encaixado na língua (cf. Barton, 1994; Baynham, 1995), tanto no uso como no sistema da língua. Em relação ao uso do letramento, a noção de discurso como a língua em uso, incluindo tanto a linguagem falada como a escrita, explica essa integração em um nível ontológico, isto é, na realidade mesma, quando um/a pesquisador/a investiga o letramento ele/a está investigando o discurso no modo como é desempenhado pelo uso da linguagem escrita. (RIOS, 2010a, p. 169) [...] Como consequência, o letramento nesse referencial faz parte de atividades materiais, tipos de relações sociais e identidades, crenças e valores específicos em uma dada comunidade, bem como contém aspectos desses diferentes elementos. (RIOS, 2010a, p. 171)

O autor afirma que o letramento é um "[...] ato sociocultural concreto constituído por pelo menos uma das seguintes atividades - escrita, leitura e fala ao redor/ sobre 
texto escrito e também sobre produções semióticas [...]”. Segundo Rios (2010a, p. 172), essas atividades se relacionam "[...] a categorias tais como valores, redes e domínios, que comumente são utilizadas na pesquisa etnográfica do letramento". As produções semióticas, nesta pesquisa, são reveladas pela multimodalidade textual e pelas formas de multiletramentos utilizadas para o reconhecimento dessas diversas modalidades de texto. Inicio a seguir os conceitos de Letramento, para, posteriormente, passar para definições mais específicas sobre Multimodalidade e Multiletramentos.

\subsection{Duas Vertentes do Letramento: Cognitivo e Sociocultural}

Neste trabalho, abordarei o letramento a partir de duas perspectivas, pois, ao observar atentamente as questões do Enem a serem analisadas, percebo que elas demandam as duas visões de letramento, cognitivo e sociocultural, por isso, neste tópico, farei uma explanação sobre elas para, nos próximos tópicos, abordar individualmente cada vertente.

Por se tratar de uma avaliação de larga escala e por ser um exame avaliativo exigido para o ingresso no Ensino Superior, o Enem difunde-se e se populariza no ambiente escolar, e é nesse lugar que normalmente o estudante tem o primeiro contato individual com o desenvolvimento da escrita, concretizando, assim, o seu letramento cognitivo, pois ele traz em seu interior vivências em sociedade de diversas formas, como o contato familiar, com amigos, etc., que possibilitam sua formação inicial de letramento.

Mas não há como analisar as questões do Enem sem trazer à baila algumas reflexões sobre letramento sociocultural, pois, para mim - em concordância com autores que serão citados posteriormente - nesta pesquisa, não há como separar essas duas vertentes de letramento. Não há como ter uma presente e não ter a outra, visto que uma trata de um letramento individual, desenvolvido interiormente, e a outra, de um letramento social, concretizado com a convivência em sociedade, levando em consideração as experiências vividas e a cultura. 
Conforme $\operatorname{Street}^{6}$ (1995, p. 30), “[...] o letramento está sendo transferido de uma cultura diferente, de modo que aqueles que o recebem serão mais conscientes da natureza e do poder dessa cultura do que dos meros aspectos técnicos da leitura e da escrita." Em consonância com Street, o letramento sociocultural, segundo Soares (2004c, p. 39), “[...] é o resultado da ação de ensinar e aprender as práticas sociais de leitura e escrita". A autora afirma que o letramento "[...] é o estado ou condição que adquire um grupo social ou um indivíduo como consequência de ter-se apropriado da escrita e de suas práticas sociais". Soares (2004b, p. 92) explica o letramento ligando-o diretamente à escrita:

Ao exercício efetivo e competente da escrita denomina-se letramento, que implica habilidades várias, tais como: capacidade de ler ou escrever para atingir diferentes objetivos - para informar ou informarse, para interagir com outros, para imergir no imaginário, no estético, para ampliar conhecimentos, para seduzir ou induzir, para divertir-se, para orientar-se, para apoio à memória, para catarse[...], habilidade de interpretar e produzir diferentes tipos e gêneros de textos; habilidades de orientar-se pelos protocolos de leitura que marcam o texto ou de lançar mão desses protocolos, ao escrever, atitudes de inserção efetiva no mundo da escrita, tendo interesse e prazer em ler e escrever, sabendo utilizar a escrita para encontrar ou fornecer informações ou conhecimentos, escrevendo ou lendo de forma diferenciada, segundo as circunstâncias, os objetivos, o interlocutor [...].

Na citação acima, Soares (2004b) revela que o conceito de letramento não aborda apenas a escrita em si, mas suas variadas habilidades, que são utilizadas como práticas discursivas e sociais para a comunicação, para aprender, ou interagir; para se distrair ou compreender; e também para lazer, como citado, ler e escrever pelo simples interesse.

Em se tratando de leitura e de escrita, dois conceitos que ainda se confundem são os de "alfabetização" e "letramento"; pois são conceitos diferentes, mas andam lado a lado. Para diferenciá-los, Soares (2004c, p. 31) define alfabetização como "[...] a ação de alfabetizar, de tornar 'alfabetizado"'. Todavia, muito além do conceito de

\footnotetext{
${ }^{6}$ Tradução da própria autora do original: “[...] literacy is being transferred from a different culture, so that those receiving it will be more conscious of the nature and power of that culture than of the mere technical aspects of reading and writing" (STREET, 1995, p. 30).
} 
alfabetização está o conceito de letramento que, como a autora explica, abrange o alfabetizar, o contexto social e as práticas de leitura e de escrita.

Apesar de sua diferenciação, esses conceitos estão interligados, porque o contato do indivíduo em fase de alfabetização com a sociedade consolida o letramento, visto que é por meio desse contato que ele interage, lê e escreve, portanto, o "simples alfabetizar" não é aqui considerado letramento, pois considero que é necessário que haja compreensão e aplicação efetiva para efetivar esse processo. Para consolidar a ligação entre os termos explicados, Soares (2004a, p. 14) evidencia:

Dissociar alfabetização e letramento é um equívoco porque, no quadro das atuais concepções psicológicas, linguísticas e psicolinguísticas de leitura e escrita, a entrada da criança (e também do adulto analfabeto) no mundo da escrita ocorre simultaneamente por esses dois processos: pela aquisição do sistema convencional de escrita - a alfabetização e pelo desenvolvimento de habilidades de uso desse sistema em atividades de leitura e escrita, nas práticas sociais que envolvem a língua escrita - o letramento. Não são processos independentes, mas interdependentes, e indissociáveis: a alfabetização desenvolve-se no contexto de e por meio de práticas sociais de leitura e de escrita, isto é, através de atividades de letramento, e este, por sua vez, só se pode desenvolver no contexto da e por meio da aprendizagem das relações fonema-grafema, isto é, em dependência da alfabetização.

A autora afirma que esses processos, alfabetização e letramento, são interdependentes, indissociáveis e simultâneos, que "[...] são processos de natureza fundamentalmente diferente, envolvendo conhecimentos, habilidades e competências específicos" (SOARES, 2004a, p. 15). Por isso, eles não são iguais, nem totalmente diferentes, mas são ligados um ao outro, cada um com suas especificidades.

Em consonância com Soares, Kleiman (2005, p. 11) contribui com a ideia de ligação entre esses termos: "O letramento não é a alfabetização, mas a inclui! Em outras palavras, letramento e alfabetização estão associados". A autora afirma que a alfabetização pode ser uma das práticas de letramento utilizadas na instituição escolar. Essa perspectiva de letramento é considerada, nesta pesquisa, como o letramento cognitivo, utilizado aqui como as práticas discursivas no ensino - as práticas de leitura e de escrita - de aprendizados no contexto escolar, fundamentais para a compreensão textual de provas de larga escala, como a prova do Enem, por exemplo,

Para concluir a diferenciação e, ao mesmo tempo, a ligação entre esses dois conceitos, o letramento e a alfabetização, Kleiman (2005, p. 14) completa: "A alfabetização (em qualquer de seus sentidos) é inseparável do letramento. Ela é 
necessária para que alguém seja considerado plenamente letrado, mas não é o suficiente". Para a autora, é preciso que haja prática de leitura e escrita na alfabetização para o domínio do sistema alfabético e ortográfico; portanto a alfabetização é apenas um passo para o letramento.

Concordando com Kleiman, Scholze e Rosing (2007, p. 20) afirmam que: "Ler um texto e interpretá-lo são duas realidades e experiências diferentes. Saber 'ler' não significa 'saber ler'”. As pesquisadoras explicam que, para ser letrado, é preciso ser alfabetizado, mas, sem a contextualização do tempo e do espaço, por exemplo, a comunicação não é eficaz. Assim, complementam: "A menos que o termo e o conceito de alfabetização venham a ser alargados para se referir também a um tipo de alfabetização cultural e social, este termo não pode ser considerado sinônimo de literacia" (SCHOLZE e ROSING, 2007, p. 20). As autoras utilizam termo "literacia" (originado do termo em inglês literacy) como sinônimo de letramento, para destacar a importância de se ter um contexto (cultural e social) para a compreensão do texto, nesse caso, o letramento sociocultural.

Para complementar a ideia do letramento sociocultural, Vieira (2007, p. 26) afirma que para ser considerado letrado o sujeito deve "[...] manejar com extrema habilidade os componentes fundamentais da escrita, como letras, palavras, ortografia, regras gramaticais, sem contar com as incontáveis noções de discurso e de pragmática".

No viés do letramento na prática social (sociocultural), para Soares (2004c), ele é um direito humano absoluto que não depende de condições econômicas ou sociais. A autora afirma que o nível de letramento da sociedade está diretamente ligado às suas condições sociais, culturais e econômicas, por isso é necessário que haja condições para o letramento. Soares $(2003$, p.18) considera que ele "[...] tem consequências sobre o indivíduo e altera o estado ou condição em aspectos sociais, psíquicos, culturais, políticos, cognitivos, linguísticos e até mesmo econômicos”. Em vista disso, é preciso que se estabeleça o letramento na prática social entre os indivíduos, pois ele tem papel fundamental na comunicação entre os membros da sociedade, seja ela qual for.

Após apresentar alguns conceitos sobre o letramento cognitivo e o sociocultural, Rios (2010b, p. 77-78) diferencia os dois, destacando suas características de acordo com o foco de pesquisa:

Qualquer concepção de letramento como processo carrega pressupostos sobre o letramento como campo de estudo. Por essa 
razão, dependendo de como o letramento é estudado, ele será visto diferentemente como um processo que ocorre na vida social. Se um/a estudioso/a parte do pressuposto de que o letramento é um ponto de chegada após um tempo de escolarização, tem-se então que para ele ou ela o que deve ser estudado é o que o indivíduo sabe fazer de leitura e escrita em decorrência desse tempo que passou na escola. Se, por outro lado, outro/a estudioso/a pensa que o letramento compreende tudo que um indivíduo tenha feito de leitura e escrita em sua vida, então estamos diante de uma visão mais ampla e aplicada a todas as esferas da vida social.

Como o meu corpus de pesquisa são questões de provas do Enem, que contêm textos variados, educativos e com conhecimentos que estão além de conteúdos específicos vistos em sala de aula, neste trabalho, me apodero destas duas vertentes do Letramento: Cognitivo (como instrumento de compreensão, descoberto no contexto escolar) e Sociocultural (na prática social, percebido nas convivências em diversos contextos vividos), as considero como descritas pelo autor acima. Por elas serem fundamentais e complementares para a leitura e compreensão dos textos que serão analisados, irei pormenorizá-las, conceituando-as nos itens a seguir.

\subsubsection{Letramento como Instrumento de Compreensão}

Para Melo e Ribeiro (2004), "letrado" pode ser alguém que frequentou ou não uma escola, mas que compreende certas estratégias de uma cultura letrada. O letramento, nesse caso, está mais voltado para a experiência cultural. Para as autoras, “[...] a concepção de letramento vai além do saber ler e escrever, pois implica saber fazer uso frequente e competente da leitura e da escrita, individual ou socialmente" (MELO e RIBEIRO, 2004, p. 25-26). Assim, o conceito de letramento é entendido como a prática de leitura e escrita e considera suas aplicações em cada contexto.

Nessa mesma perspectiva, Tfouni (1988) argumenta que, nas sociedades modernas, não existem pessoas “iletradas”, o que há são vários graus de letramento, que podem ser considerados como um "continuum" e que, ao mesmo tempo, estão interligados ao processo de alfabetização. Para a pesquisadora, parece questionável que a aquisição da escrita tem como consequência cognitiva: “[...] o desenvolvimento do pensamento lógico, e a capacidade para compreender e produzir silogismos" (TFOUNI, 1988, p. 20). Assim, com as questões do Enem, é possível refletir que, conforme suas experiências de leitura, as pessoas desenvolvem melhor sua compreensão e, 
consequentemente, suas habilidades para interpretações e inferências. Nesse sentido, é preciso considerar que o público inscrito no Enem é diversificado, pode ser o formando do Ensino Médio ou o graduado em busca de mais uma formação, pode ter pouco desenvolvimento do pensamento lógico ou boa carga de leitura e escrita, tendo ou não, portanto, capacidade cognitiva mais desenvolvida.

O letramento cognitivo é entendido aqui como a utilização de estratégias mentais próprias no ato de compreender, adquiridas principalmente no contexto escolar e em outros contextos frequentados pelo indivíduo, como igreja, lar, trabalho etc. Quanto à dimensão cognitiva do letramento na escola, Melo e Ribeiro (2004, p. 59) explicam que:

[...] ensinar a ler e a escrever é mobilizar um conjunto diferenciado de operações mentais, é propiciar ao aluno condições de se apropriar de um conjunto de capacidades que não são apenas linguísticas, mas cognitivas, em processo de produção de sentido. Essas capacidades, no entanto, não surgem apenas do desejo de ler, mas, em especial, dos esforços pedagógicos que possam conduzir ao desenvolvimento de habilidades tais como as inferências, as antecipações, a contextualização, a localização de informação, as deduções explícitas e implícitas, a descoberta de pistas. Ler e escrever exige habilidades e conhecimento de mundo, de língua e de texto.

Ao observar as questões do Enem, constato claramente requisitos de habilidades de leitura como as citadas por Melo e Ribeiro (2004), logo verifico a presença de questões interdisciplinares e contextualizadas que exigem do candidato compreensão e interpretação, e que possibilitam que ele utilize sua experiência como leitor provido de conhecimentos linguísticos e extralinguísticos adquiridos ao longo de sua vida escolar e extraescolar.

Sobre os aspectos cognitivos de aquisição de escrita na escola, Kleiman (1995, p. 39) aponta que eles “[...] devem ser entendidos em relação às estruturas culturais e de poder que o contexto de aquisição da escrita na escola representa". Por ser um local culturalmente direcionado ao aprendizado, a escola assume o papel principal do letramento cognitivo. Quanto à escola, nesse quesito, Kleiman (1995, p. 20) complementa:

Pode-se afirmar que a escola, a mais importante das agências de letramento, preocupa-se não com o letramento, prática social, mas com apenas um tipo de prática de letramento, a alfabetização, o processo de aquisição de códigos (alfabético, numérico), processo 
geralmente concebido em termos de uma competência individual necessária para o sucesso e promoção na escola. Já outras agências de letramento, como a família, a igreja, a rua como lugar de trabalho, mostram orientações de letramento muito diferentes.

Ainda quanto à prática de letramento no ambiente escolar, Soares (2004b) argumenta que a escola "autonomiza" as atividades de leitura e de escrita, criando suas próprias práticas de letramento. Nesse ponto, Street (1995 apud SOARES, 2004b, p. 107) chama para essa pedagogização do letramento. $O$ autor explica esse processo afirmando que, no ambiente escolar, a leitura e a escrita, “ [...] integram eventos e práticas sociais específicas, associadas à aprendizagem, de natureza bastante diferente dos eventos e práticas associados a objetivos e a concepções não escolares”.

Sobre o contexto mais comum do letramento pela perspectiva cognitiva, o escolar, e seu extravasamento para outros ambientes, Soares (2004b, p.109) destaca:

[...] o letramento escolar acaba por dominar o letramento social: ultrapassa as paredes da escola, como consequência do prestígio dessa instituição como instância social e cultural, de tal forma que o conceito escolar de letramento contamina os eventos e práticas no contexto extraescolar, impondo comportamentos escolares de letramento e marginalizando outras variedades de letramento próprias desse contexto. [...] é como se o letramento social, passando pelo crivo da escolarização, retornasse à sociedade "corrompido" pelo letramento escolar.

As contribuições de Soares (2004b) remetem à importância do letramento escolar e, ao mesmo tempo, à acomodação cultural quanto à ideia de que é na escola que se deve desenvolver o letramento. Essa ideia, como relata Soares, torna a sociedade "corrompida" pelo letramento escolar (cognitivo), esperando-se "técnicas" de ensino para o desenvolvimento do letramento, quando não há técnicas, mas naturalidade na propagação do letramento extraescolar (sociocultural). O ambiente escolar é, sim, essencial para esse segmento, mas não o único, visto que o contexto extraescolar é também fundamental, pois retrata as práticas sociais, promovendo, assim, o letramento sociocultural.

Em se tratando de letramento cognitivo, uma vez que o estudante é alfabetizado na escola, ele passa a desenvolver seus processos mentais cognitivos tanto nesse ambiente quanto em outros de sua convivência. Sobre isso, Melo e Ribeiro (2004, p. 25) afirmam que “[...] frequentar uma escola não garante, por si só, o desenvolvimento ou a 
aquisição de competência em muitas ou em todas as práticas sociais de oralidade, leitura e escrita". Por isso, é preciso que haja uma busca interdisciplinar pelo letramento, um comprometimento dialógico entre as práticas pedagógicas e as relações entre linguagem e sociedade. Ainda sobre o letramento como instrumento de compreensão, Kleiman (1989, p. 10) contribui:

De fato, a compreensão de um texto escrito envolve a compreensão de frases e sentenças, de argumentos, de provas formais e informais, de objetivos, de intenções, muitas vezes de ações e de motivações, isto é, abrange muitas das possíveis dimensões do ato de compreender, se pensamos que a compreensão verbal inclui desde a compreensão de uma charada até a compreensão de uma obra de arte.

A autora destaca que quanto mais conhecimento textual o leitor tiver, mais fácil será sua compreensão, pois, se o leitor estiver exposto a vários tipos de textos, ele conhecerá suas estruturas e esse conhecimento exercerá papel fundamental para a compreensão. Kleiman (1995, p. 150) também argumenta que a forma como as pessoas controlam sua produção cognitiva é “[...] relevante na distinção de modalidades de funcionamento intelectual mais e menos ligadas a características letradas".

Sobre a linguagem escrita, Scribner e Cole (1981 apud TFOUNI, 1988, p. 20) afirmam que ela "[...] promove conceitos abstratos, raciocínio analítico, novos modos de categorização, uma abordagem lógica à linguagem”. Kleiman (1989, p.14-15) complementa que: "O conhecimento linguístico desempenha um papel central no processamento do texto". A partir das contribuições dos autores, é possível depreender que, se o leitor tiver vasto conhecimento linguístico, ele desvendará mais facilmente esses conceitos abstratos trazidos pelo texto escrito.

Sobre esse aspecto, Scribner e Cole (1981 apud TFOUNI, 1988, p. 33) afirmam que a linguagem escrita “[...] tem uma sintaxe apropriada para a expressão de relações analíticas. E é durante a sua produção que o escritor é forçado a engajar-se em operações abstratas". Para os autores, com a linguagem escrita, há o aparecimento de operações intelectuais, pois ela permite avaliar se há inconsistência de raciocínio, possibilitada pelo contato com a escrita. Para complementar o quesito compreensão cognitiva da linguagem escrita, Kleiman (1989, p. 154) argumenta:

A própria escrita enquanto sistema simbólico é, quase por definição, um dos principais fundamentos do modo letrado de pensamento. 
Separando o produto escrito de seu autor e do tempo e do local de sua criação, separando signo de significado, permitindo o exame repetido de registros gráficos, a escrita favorece o pensamento descontextualizado e independente da experiência do sujeito. Favorece também a consciência metalinguística, por consistir em suporte material da língua, sobre o qual o sujeito pode refletir e construir conhecimento explícito, e a consciência metacognitiva, pela possibilidade de verificação do discurso escrito enquanto produto de pensamento, de objetivação da experiência pessoal.

É por meio da escrita que o sujeito pode se comunicar e expressar variadas ideias, todavia concordo com Kleiman (1989) quanto ao aspecto descontextualizado que a escrita pode assumir, dependendo do âmbito e do momento em que ela aparece. $\mathrm{O}$ fato de a escrita vir geralmente desacompanhada de seu escritor também é o que a torna, em muitas ocorrências, descontextualizada. Ao mesmo tempo, a escrita é objeto de construção de conhecimentos explícitos e implícitos, o que pode ser definido pela experiência, pelo pensamento do leitor e pela funcionalidade do produto escrito em determinado contexto social.

Segundo Kleiman (2008), a escrita deve ser pluralista e multicultural, e, por ser aplicada em diversos ambientes socioculturais, os indivíduos constroem suas possibilidades de ação sobre o conhecimento, superando as limitações do contexto da vida cotidiana. Assim, eles colocam esses conhecimentos em prática em ambientes diversos, seja em lugares mais ligados diretamente ao letramento - por exemplo, a escola -, seja em outros ambientes que possibilitam reflexão sobre o letramento e/ou ambientes de transformação social.

Ao analisar os textos das questões do Enem nesta pesquisa, observo que o letramento cognitivo e o letramento sociocultural são requisitos necessários para a leitura e a compreensão. Por isso, é preciso levar em consideração as contribuições dos autores citados, pois verifico que o letramento sociocultural também precisa ser melhor detalhado, pois essas duas vertentes, aqui neste trabalho e para mim, são indissociáveis, portanto, sigo apresentando o letramento sociocultural.

\subsubsection{Letramento na Prática Social}

Ao observar o corpus desta pesquisa, noto a pertinência de se aprofundar um pouco mais sobre o letramento sociocultural, pois ele está nas entrelinhas dos textos, percebido em textos com assuntos diversos que podem ser socializados em diferentes 
práticas sociais, pautando-se em conhecimentos linguísticos e conhecimentos compartilhados, assim sendo, é imprescindível considerá-los no contexto desta pesquisa.

Em se tratando de contexto social, Rios (2010a, p. 172) explica a relação entre o letramento e a prática social, citando que "[...] a estrutura linguística importa na constituição das práticas sociais", assim o letramento está diretamente ligado à prática e não poderia ser entendido separado dela, sendo necessário verificar o contexto social em que ele é aplicado para verificar a eficácia de sua comunicação. Ainda sobre essa perspectiva do letramento, James Gee (1990 apud RIOS, 2010a, p. 168) afirma que "[...] é somente dentro do contexto da noção de Discurso que podemos alcançar uma definição viável de 'letramento"'. Rios (2010a) considera o Discurso como sendo socialmente significativo, o que justifica o argumento de ter o letramento dentro de determinado discurso.

Em consonância com Rios (2010a), Barton et al (2002, p. 8) também contribuem com a ideia de que o letramento é melhor entendido nas práticas sociais, mesmo que essas surjam a partir de eventos que são mediados por textos escritos. É necessário que haja a inserção das práticas de letramento em contextos sociais, pois, dependendo do contexto, o entendimento muda ou se adequa. Sobre isso, Street (2012 apud BEVILAQUA, 2013, p. 104) afirma que o letramento será “[...] reformulado, reapropriado diferentemente de acordo com o contexto em que estiver inserido e de acordo com a identidade dos sujeitos membros de uma comunidade". Para complementar esse ponto de vista, Barton (1994, p. 5) explica que o termo "letramento" é muito mais complexo que apenas leitura e escrita, por isso ele nos aponta algumas contribuições que o estudo do letramento na prática social tem trazido ${ }^{7}$ :

\footnotetext{
subjects, people are making some contribution to the contemporary study of literacy:

- historical development

- the study of different cultures and subcultures

- oral cultures without literacy

- written and spoken language

- literacy and thought

- $\quad$ processes of reading and writing

- learning in schools

- pre-school literacy, emergent literacy

- learning at home, in the comunity, at work

- adult learning, adult literacy; adults returning to study

- the politics of literacy, literacy and power" (BARTON, 1994, P. 5)
}

${ }^{7}$ Tradução minha do texto original : "Across a range of disciplines the term literacy has become a code word for more complex views of what is involved in reading and writing. In each of the following 
- desenvolvimento histórico

- o estudo de diferentes culturas e subculturas

- culturas oralizadas sem alfabetização

- linguagem escrita e falada

- letramento e pensamento

- processos de leitura e escrita

- aprendizagem nas escolas

- letramento pré-escolar, letramento emergente

- aprendizagem em casa, na comunidade, no trabalho

- aprendizagem adulta, letramento adulto; adultos voltando a estudar

- as políticas de alfabetização, letramento e poder

Por meio dos apontamentos acima, assevero que o letramento é parte de vivências históricas, sociais e culturais, percebido de diversas formas, não somente pela escrita, mas também pela oralidade. O letramento faz parte do pensamento, da compreensão oral e escrita, das inferências; ele pode ser adquirido dentro ou fora da escola em diversos ambientes de convivência social.

O letramento sociocultural está inserido em praticamente todas as práticas sociais em que o indivíduo se encontra/envolve. Essas práticas, em determinados ambientes, são denominadas como eventos de letramento e são explicadas por Heath (1982) e Street (1995 apud SOARES, 2004b, p. 105):

Por eventos de letramento designam-se as situações em que a língua escrita é parte integrante da natureza da interação entre os participantes e de seus processos de interpretação (HEATH, 1982:93), seja uma interação face a face, em que pessoas interagem oralmente com a mediação da leitura ou da escrita (por exemplo: discutir uma notícia do jornal com alguém, construir um texto com a colaboração de alguém), seja uma interação a distância, autor-leitor ou leitor-autor (por exemplo, escrever uma carta, ler um anúncio, um livro). Por práticas de letramento designam-se tanto os comportamentos exercidos pelos participantes num evento de letramento quanto as concepções sociais e culturais que o configuram, determinam sua interpretação e dão sentido aos usos da leitura e/ou da escrita naquela particular situação. (STREET, 1995a:2)

Consoante Heath e Street, Rios (2010b, p. 79) explica que o letramento se inicia a partir do contato da pessoa com a escrita ou com a fala, o que comumente acontece em casa. $\mathrm{O}$ autor também considere a fala, porque as pessoas geralmente reproduzem a linguagem de textos, por exemplo, uma história contada pelos pais - o que, para o 
pesquisador, reflete a prática de letramento. Essa prática da leitura, da escrita e da oralidade no ambiente doméstico motiva o estudante a buscar mais e, consequentemente, a estar mais habilitado a diversas leituras.

Sobre o ambiente linguístico do lar, Snowling e Hulme (2013) afirmam que algumas diferenças culturais e socioeconômicas podem ser observadas no desempenho escolar do estudante, assim, se ele for mais incentivado, ele poderá apresentar mais facilidade e motivação para o desenvolvimento da leitura e da escrita.

A partir do contato inicial com o letramento, o indivíduo passa a fazer parte de uma ampla gama de práticas sociais em que aprimora suas habilidades e adquire outras. Para a visão e a prática integradas de letramento, segundo Barton (1994), há três áreas de pesquisa, que devem andar lado a lado, são elas: a social, a psicológica e a histórica. Dentro dessas áreas, o autor define outras subáreas apresentadas a seguir ${ }^{8}$ :

a) Visão social do letramento:

1. Práticas e eventos - o letramento é uma atividade social e pode ser melhor descrita em termos das práticas de letramento nas quais as pessoas se baseiam em eventos de letramento.

2. Letramento e domínios - as pessoas têm diferentes letramentos de que fazem uso, associados a diferentes domínios da vida. Examinar diferentes culturas ou períodos históricos revela mais letramentos.

\footnotetext{
${ }^{8}$ Tradução minha do texto: "An integrated view of literacy [...] to bring them together this approach starts out from three areas of enquiry: the social, the psycological and the historical. [...] 1. Practices and events - literacy is a social activity and can best be described in terms of the literacy practices which people draw upon in literacy events.

2. Literacies and domains - people have different literacies which they make use of, associated with different domains of life. Examining different cultures or historical periods reveals more literacies.

3. Roles and networks - people's literacy practices are situated in broader social relations. This makes it necessary to describe the social setting of literacy events, including the ways in which social institutions support particular literacies.

4. Literacy as communication - literacy is based upon a system of syombols. It is a symbolic system used for communication and as such exists in relation to other systems of information exchange. It is a way of representing the world to others.

5. Literacy as thought - literacy is a symbolic system used for representing the world to ourselves. Literacy is part of our thinking. It is part of the technology of thought.

6. Values and awareness - we have awareness, atittudes and values with respect to literacy and these atittudes and values guide our actions.

7. Individual history - literacy has a history. Our individual life histories contain many literacy events from early childhood onwards which the presente is built upon. We change and as children and adults are constantly learning about literacy.

8. Social history - a literacy event also has a social history. Current practices are created out of the past." (BARTON, 1994, p. 33-35)
} 
3. Funções e redes - as práticas de letramento das pessoas estão situadas em relações sociais mais amplas. Isso torna necessário descrever o cenário social dos eventos de letramento, incluindo as formas como as instituições sociais apoiam letramentos particulares.

4. Letramento como comunicação - o letramento é baseado em um sistema de símbolos. É um sistema simbólico utilizado para a comunicação e, como tal, existe em relação a outros sistemas de troca de informações. É uma maneira de representar o mundo para os outros.

b) Visão psicológica do letramento:

5. Letramento como pensamento - o letramento é um sistema simbólico usado para representar o mundo para nós mesmos. O letramento é parte de nosso pensamento. Ele é parte da tecnologia do pensamento.

6. Valores e consciência - nós temos consciência, atitudes e valores em relação ao letramento e essas atitudes e valores que orientam nossas ações.

c) Visão histórica do letramento:

7. História individual - o letramento tem história. Nossas histórias individuais de vida contêm muitos eventos de letramento desde a primeira infância até o presente construído. Nós mudamos e, assim como as crianças, os adultos estão constantemente aprendendo sobre letramento.

8. História social - um evento de letramento também tem uma história social. As práticas atuais são criadas fora do passado.

O letramento é muito mais que a leitura e a escrita, é a convivência social, é a transmissão cultural em determinados contextos sociais, portanto ele varia conforme os meios sociais que o indivíduo frequenta (SCRIBNER, 1984, apud RIOS, 2010b). Sobre sua importância social, Baynham (1995 apud RIOS, 2010b, p. 87) afirma que o letramento é ideológico e pode ser crítico; alem diso, que ele “[...] tem sido desenvolvido e modelado para servir a propósitos sociais de criar e intercambiar sentidos [...]", que ele é melhor compreendido em contexto de uso. Para explicitar melhor o letramento sociocultural, apresento o quadro da Teoria Social do Letramento, de Barton e Hamilton (1998; 2000 apud RIOS, 2010b, p. 89): 
Quadro 2 - Teoria Social do Letramento

- O letramento é mais bem compreendido como um conjunto de práticas sociais que podem ser inferidas de eventos que são mediados por textos escritos.

- Há diferentes letramentos associados a diferentes domínios da vida.

- As práticas de letramento são padronizadas por instituições sociais e relações de poder, e alguns letramentos são mais dominantes, visíveis e influentes do que outros.

- As práticas de letramento são propositadas e encaixadas em práticas culturais e objetivos sociais mais amplos.

- O letramento é historicamente situado.

- As práticas de letramento mudam e novas práticas são frequentemente adquiridas por meio de processos de aprendizagem informal e produção de sentido.

Fonte: RIOS (2010b, p. 89).

Os autores afirmam que práticas de letramento são hábitos praticados com o letramento, o que abrange a consciência e os discursos das pessoas sobre letramento, processos sociais de comunicação e compreensão, e incluem conhecimentos compartilhados. Quanto às práticas de letramento, Soares (2004b, p. 27) destaca que o indivíduo letrado "[...] é não só aquele que sabe ler e escrever, mas aquele que usa socialmente a leitura e a escrita, pratica a leitura e a escrita, responde adequadamente às demandas sociais de leitura e escrita". Soares (2004b, p. 27-28) completa esse posicionamento ao explicar que:

Nesse sentido, o letramento é complexo e heterogêneo, pois tem uma dimensão individual e uma social. Na dimensão individual, é um atributo pessoal de posse de tecnologias mentais de ler e escrever. $\mathrm{Na}$ dimensão social, é um fenômeno cultural, pois se trata de atividades sociais que envolvem a escrita e de exigências sociais de uso dessa escrita.

Para complementar as considerações de Soares (2004b), Melo e Ribeiro (2004) definem letramento como práticas discursivas da linguagem, quanto às modalidades fala, leitura e escrita. Elas afirmam que essas práticas podem ser realizadas em diversas situações, espaços e atividades, dessa forma, quem “[...] aprende a ler e a escrever e a falar certamente poderá desenvolver-se culturalmente, entendendo cultura como aceitação, compreensão e ampliação de todos os saberes” (MELO e RIBEIRO, 2004, p. 57). Com relação a esse posicionamento, Barton (1994) acentua que o letramento tem de ser analisado dentro de um contexto social, na leitura e na escrita em determinada situação. 
Logo, quem não é alfabetizado e não desenvolveu habilidade de escrever poderá ter o seu desenvolvimento sociocultural um pouco menos desenvolvido, pois será "privado" da leitura e da escrita - duas modalidades consideradas aqui como quesitos do letramento, mas se comunicará por meio da fala, também definida como uma das práticas discursivas do letramento.

A partir das considerações dos autores, pode-se reconhecer que a linguagem é um produto social e o letramento retrata experiências coletivas, assim as pessoas devem ser letradas o suficiente para compreenderem diversos textos presentes na comunicação atual.

Observo, então, que as mudanças na escrita e nas práticas sociais ocorrem conforme o desenvolvimento socioeconômico e cultural, por isso é necessário que as práticas estejam sempre atualizadas, pois a língua é viva e está em constante mudança. Com as mudanças discursivas e textuais, nos voltamos para um novo parâmetro de texto: o texto multimodal, que utiliza outros recursos semióticos para a sua compreensão, visto que esses textos são instrumentos diretos desta pesquisa, apresentarei pontos essenciais sobre eles no tópico seguinte.

\subsection{Multimodalidade Textual na Contemporaneidade}

A comunicação textual vem sendo atualizada conforme as mudanças dos meios sociais. Hoje, os textos escritos abrem ainda mais espaço para outras modalidades, o que modifica a compreensão de acordo com as práticas de letramento presentes na sociedade. Ao olhar para a prática textual, é quase impossível encontrar um texto que não seja multimodal, pois eles são vistos das mais diversas formas, com elementos semióticos que por si só os tornam multimodais, como tipo e tamanho da fonte, uso de imagens, cores, gráficos, tabelas, disposição dos elementos textuais, etc.

Kress e van Leeuwen (2001) relatam que a multimodalidade é baseada não apenas nos modos semióticos, mas na análise das especificidades e dos traços comuns dos aspectos sociais dos modos semióticos. Os autores afirmam que a comunicação depende da "comunidade interpretativa" e de quais aspectos são articulados para serem interpretados. Os estudiosos argumentam também que "[...] toda ação social é semiótica e toda ação semiótica é social” (KRESS e VAN LEEUWEN, 2001, p. 36). Assim todo texto pode ser considerado ação semiótica, visto que os textos são ações sociais. 
Quanto aos modos semióticos, os autores destacam que9: “ [...] são moldados tanto pelas características intrínsecas e potencialidades do meio quanto pelos requisitos, histórias e valores das sociedades e suas culturas" (KRESS e VAN LEEUWEN, 2006, p. 35). Os pesquisadores apontam que os significados pertencem à cultura, portanto as formas como os modos semióticos são utilizados nos textos sofrem influência cultural e histórica, isso pode justificar a escolha por alguns textos apenas visuais, outros verbais, e outros multimodais.

Trajano (2013, p.35) complementa esse ponto ao afirmar que "[...] as imagens carregam significados específicos, e as palavras carregam outros. Elas não são completamente unidas nem inteiramente opostas". As imagens podem estar relacionadas ao texto verbal, mas essa relação nem sempre existirá, pois, em alguns textos, as imagens podem ser autoexplicativas, o que passará, nesse caso, a não depender da linguagem verbal.

Quanto às mudanças com a inserção de textos multimodais na comunicação, Trajano (2013, p.53) afirma que estão presentes no cotidiano, “[...] haja vista as campanhas publicitárias contemporâneas repletas de textos multimodais, nas quais vários modos semióticos estão conjuntamente trabalhando na produção de significados do discurso". A autora acrescenta que, com a presença dos textos multimodais diariamente na sociedade, é necessário que se tenha outro tipo de interpretação, para um entendimento mais abrangente da escrita e da leitura, pois outros modos semióticos contribuem para a construção de novos significados.

Sobre a inclusão de semioses diversas no discurso, Ferraz (2005, p. 387) afirma que o propósito é “[...] mostrar a ligação das práticas discursivas com as estruturas sócio-político-econômicas, por meio de uma análise que dê conta tanto da estrutura interna quanto da organização global dos textos”. Esse argumento me remete à importância de se ter entendimento global de um texto, levando em consideração as modalidades presentes nele e a história da sociedade em que o texto foi produzido.

Ainda sobre a inclusão desse novo código de texto e imagem na atualidade, Kress e van Leeuwen (1996 apud FERRAZ, 2005) acentuam que hoje a informação é

\footnotetext{
9 Tradução minha do texto original: "[...] are shaped both by the intrisic characteristics and potentialities of the medium and by the requirements, histories and values of societies ant their cultures." (KRESS E van LEEUWEN, 2006, p. 35)
} 
transmitida de forma diversa pelos dois modos e que essa nova comunicação não é menos complexa, mas é uma relação de complexidade e demanda cognitiva diferente. Na mesma linha de raciocínio, Vieira et al (2007, p. 19) revelam que "A invasão das imagens nas práticas de escrita abre espaço para mudanças no discurso e coloca em evidência principalmente a linguagem visual". A linguagem visual prende a atenção do leitor, que, às vezes, é chamado a ler o texto pela imagem, e ainda há casos de textos nos quais não há texto verbal. Os autores completam que:

[...] Independente da sua vontade, o sujeito da sociedade mediada por inúmeros e variados meios de comunicação deve não apenas se familiarizar com a multimodalidade textual, capaz de construir textos predominantemente imagéticos, como também construir aparato crítico que lhe permita lidar com essa nova realidade textual. (VIEIRA ET AL, 2007, p. 25)

Conforme Ferraz (2005), os textos demonstram as mudanças na linguagem, eles registram as práticas discursivas encontradas nas práticas sociais, assim podemos dizer que o texto acompanha as mudanças sociais, pois faz parte de suas práticas. A autora traz as considerações de Kress, Leite-Garcia e van Leeuwen (2000) sobre a concepção semiótica dos textos multimodais por meio de alguns pressupostos:

- a produção ou a leitura de textos sempre envolve conjuntos de modos semióticos;

- cada modalidade tem suas potencialidades específicas de representação e de comunicação, produzidas culturalmente;

- a maneira de ler os textos multimodais deve considerar os textos coerentes em si mesmos;

- tanto os produtores quanto os leitores exercem poder em relação aos textos;

- escritores e leitores produzem signos complexos - textos - que emergem do interesse do "produtor" do texto;

- o "interesse" descreve a convergência de um complexo conjunto de fatores: histórias sociais e culturais, contextos atuais e ações dos produtores dos signos sobre o contexto comunicativo;

- o "interesse" em representações aptas e em uma comunicação efetiva significa que os produtores de signos elegem significantes (formas) apropriadas para expressar significados (sentidos), de maneira que a relação entre significante e significado é motivada e não arbitrária. (KRESS, LEITE-GARCIA e VAN LEEUWEN (2000) apud FERRAZ, 2015, P. 378) 
Ao estabelecer a ligação entre a teoria e os textos do Enem, percebo que é comum haver uma variedade de textos multimodais que envolvem várias semioses. As mais presentes nesse contexto são as imagens, que prendem a atenção do leitor e, na maioria das vezes, facilitam a compreensão, tornando o texto mais coerente. Também verifico que os textos são escritos de acordo com o interesse do escritor, mas, como o Enem é uma prova interdisciplinar e atualizada, prevalece nele a seleção de textos diversificados, o que pode possibilitar maior identificação dos candidatos que fazem o exame com os textos, proporcionando também melhor compreensão.

Ao observar a comunicação textual atual, Soares e Vieira (2013, p. 237) postulam que: “[...] dominar novas linguagens é indispensável como forma inclusive de letramento, pois a completa compreensão da linguagem possibilita leituras mais atentas nos diversos gêneros e mídias". Isso porque, atualmente, nos deparamos com diferentes meios tecnológicos que propagam uma diversidade semiótica e que requerem leitores evoluídos, aptos a compreenderem essas semioses.

Partindo das reflexões teóricas apresentadas, nesta pesquisa, para analisar a multimodalidade presente nos textos das questões do Enem, utilizarei algumas categorias de análise da GDV, pois as considero pertinentes para estudar que tipos de textos multimodais há no Enem e como eles são utilizados para compor o sentido das questões. As categorias da GDV serão apresentadas no capítulo metodológico. Para seguir com as contribuições sobre as novas tecnologias e a compreensão da linguagem multimodal, passarei para o item que descreve algumas possíveis relações entre os Multiletramentos e a Multimodalidade.

\subsubsection{Multiletramentos e Multimodalidade: uma prática social multissemiótica}

Como a Multimodalidade foi definida no item anterior, iniciarei este tópico descrevendo os Multiletramentos e seguirei apresentando algumas relações importantes entre os dois termos. As discussões têm início em 1994, em Londres, quando surgiu The New London Group, um grupo formado por dez acadêmicos de três países diferentes: Courtney Cazden, James Gee e Sarah Michaels (dos Estados Unidos); Norman Fairclough e Gunther Kress (do Reino Unido); Bill Cope, Mary Kalantzis, Allan Luke, Carmen Luke e Martin Nakata (da Austrália). 
Esses estudiosos se reuniram em uma cidade pequena de New London - New Hampshire, para debater o futuro do ensino do letramento, e para ${ }^{10}$ “[...] discutir o que precisaria ser ensinado em um futuro próximo em contínua mudança, e como isso deveria ser ensinado [...]" (COPE e KALANTZIS, 2000, p. 3). Sobre esse encontro, do qual Bill Cope e Mary Kalantzis também fizeram parte, eles explicam que ${ }^{11}$ :

Criar um contexto para a reunião foram as nossas diferenças de experiência nacional e diferenças de ênfase teórica e política. Por exemplo, nós precisávamos debater amplamente a importância relativa da imersão e do ensino explícito; nossos diferentes interesses como especialistas nas áreas de multimídia, letramento no local de trabalho e diversidade cultural e linguística; e a questão da dimensão do compromisso que deveríamos ter com as expectativas de aprendizagem e o caráter das novas formas de organização no local de trabalho. Nós nos envolvemos nas discussões com base em um genuíno compromisso com a resolução colaborativa de problemas, reunindo uma equipe com conhecimentos, experiências e posições diferentes, a fim de otimizar a possibilidade de abordar efetivamente a complexa realidade das escolas (COPE e KALANTZIS, 2000, p. 4).

Para alcançar suas aspirações, Cope e Kalantzis (2000) afirmam que os estudiosos que se reuniram concordavam com alguns pontos a serem discutidos especificamente:

a) a questão dos resultados sociais sobre o aprendizado de línguas;

b) a Pedagogia do Letramento como influência de práticas que proporcionem habilidades e conhecimentos aos alunos;

c) a mudança constante do que os alunos precisam aprender;

d) o próprio termo Pedagogia do Letramento que estava mudando radicalmente.

Então, ainda segundo Cope e Kalantzis (2000), os pesquisadores reunidos decidiram resumir as discussões realizadas em uma palavra: "Multiletramentos", pois nela estariam descritos dois argumentos principais de acesso a textos: a multiplicidade

\footnotetext{
${ }^{10}$ Texto original traduzido pela própria autora: "to discuss what would need to be taught in a rapidly changing near future, and how this should be taught." (COPE e KALANTZIS, 2000, p. 3)

${ }^{11}$ Texto original traduzido pela própria autora: "Creating a context for the meeting were our differences of national experience and differences of theoretical and political emphasis. For instance, we needed to debate at length the relative importance of immersion and explicit teaching; our differing expert interests in the areas of multimedia, workplace literacies, and cultural and linguistic diversity; and the issue of the extent to which we should compromise with the learning expectations and ethos of new forms of workplace organisation. We engaged in the discussions on the basis of a genuine commitment to collaborative problem-solving, bringing together a team with different knowledge, experiences, and positions in order to optimise the possibility of effectively addressing the complex reality of schools." (COPE e KALANTZIS, 2000, p. 4).
} 
de canais de comunicação e mídia; e o crescente destaque da diversidade cultural e linguística.

Quanto aos dois argumentos usados para defender o termo Multiletramentos Cope e Kalantzis (2000) ressaltam que eles sempre possuem as seguintes características: são interativos e colaborativos; transgridem relações de poder e de propriedade estabelecida, por exemplo, por máquinas, ferramentas, ideias e textos verbais ou não; e são "híbridos, fronteiriços, mestiços (de linguagem, modos, mídias e culturas) (ROJO e MOURA, 2012, p. 23). Considero a definição de textos híbridos feita pelos pesquisadores como relevantes para a compreensão do texto multimodal, assim, o texto híbrido aqui é um texto que pode envolver diversas linguagens, "modos, mídias e culturas", como citado pelos autores.

Para definir os Multiletramentos, Rojo e Moura (2012, p. 8) destacam que:

Trabalhar com multiletramentos pode ou não envolver (normalmente envolverá) o uso de novas tecnologias de comunicação e de informação ("novos letramentos"), mas caracteriza-se como um trabalho que parte das culturas de referência do alunado (popular, local, de massa) e de gêneros, mídias e linguagens por eles conhecidos, para buscar um enfoque crítico, pluralista, ético e democrático - que envolva agência - de textos/discursos que ampliem o repertório cultural, na direção de outros letramentos [...].

Sobre os sentidos dos Multiletramentos, Rojo e Moura (2012) especificam dois aspectos:

1. A multiplicidade cultural das populações (diversidade cultural e linguística): em que há a presença, em diversos eventos discursivos, de textos híbridos de diferentes letramentos, produzidos por escolha pessoal, política e socioeconômica. Este aspecto caracteriza-se por um processo de "[...] desterritorialização, de descoleção e de hibridação [...]" (GARCÍA CANCLINI, 2008[1989] apud ROJO e MOURA, 2012, p. $16)$;

2. A multiplicidade semiótica de constituição dos textos (multiplicidade de canais de comunicação e mídia): em que há vários gêneros de discurso, “[...] novas mídias, tecnologias, línguas, variedades, linguagens [...]" (ROJO e MOURA, 2012, p. 16). A multiplicidade semiótica tem "significado multiplicador", assim "[...] vários letramentos e tradições culturais combinam essas modalidades semióticas diferentes para construir 
significados que são mais que a soma do que cada parte poderia significar separadamente” (LEMKE 2010[1998] apud ROJO e MOURA, 2012, p. 20).

De acordo com Cope e Kalantzis (2000), os Multiletramentos abordam diferentes formas de cultura e de contexto, as quais produzem alguns efeitos cognitivos, culturais e sociais. Por exemplo, em algumas sociedades, o modo visual de representação pode ser mais utilizado e representar mais importância, enquanto em outras o modo auditivo pode apresentar mais relevância, ou o textual, etc.

Ao final do encontro, o Grupo de Nova Londres (GNL) propôs quatro elementos para uma Pedagogia dos Multiletramentos ${ }^{12}$ :

1. Prática situada - é o conhecimento consciente; a prática situada requer um usuário funcional, que tenha competência técnica e/ou conhecimento prático para personalizar (ressignificar) experiências que tenham significado em diversas práticas e eventos discursivos, como no local de trabalho e em espaços públicos, por exemplo.

2. Instrução aberta - é a instrução explícita, ou seja, são práticas ligadas diretamente à aprendizagem. A instrução aberta requer um leitor criador de sentidos, que compreenda diferentes textos e tecnologias operantes; a partir da instrução aberta, pode-se desenvolver uma metalinguagem que descreva ou interprete as diferentes formas de significado dos Multiletramentos ligados ao ensino.

3. Enquadramento Crítico - é a interpretação crítica; é o enquadramento consciente da teoria na prática em contextos históricos, sociais e culturais de produção de significado; é não só a transformação fidedigna de teoria em prática, mas também a contribuição pessoal da experiência do leitor, por isso crítica. $\mathrm{O}$ enquadramento crítico requer um leitor que seja analista crítico, que entenda que tudo que ele estuda é fruto de seleção prévia.

4. Prática transformada - é a recriação de significados; a prática transformadora requer um leitor transformador, que use o que ele aprendeu de novos modos,

\footnotetext{
${ }^{12}$ Texto parafraseado do original: "We also considered four components of pedagogy: Situated Practice, which draws on the experience of meaning-making in lifeworlds, the public realm, and workplaces; Overt Instruction, through which students develop an explicit metalanguage of Design; Critical Framing, which interprets the social context and purpose of Designs of meaning; and Transformed Practice, in which students, as meaning makers, become designers of social futures". (COPE e KALANTZIS, 2000, p. 7).
} 
que transforme teorias em novas práticas, baseadas em valores e objetivos em determinados contextos sociais.

Para explicar os elementos da proposta de Pedagogia dos Multiletramentos, Rojo e Moura (2012, p. 30) afirmam que a prática situada proporciona "[...] imersão em práticas que fazem parte da cultura do alunado [...]"; enquanto a instrução aberta exerce o seu papel sobre a prática situada, analisando-as sistematicamente por meio do enquadramento crítico. Todo esse processo produz uma prática transformadora de recepção ou de produção/ distribuição.

Conforme o Grupo de Nova Londres, os quatro elementos descritos acima compõem uma proposta didática para uma Pedagogia dos Multiletramentos, com a qual "O trabalho da escola sobre esses alfabetismos ${ }^{13}$ estaria voltado para as possibilidades práticas de que os alunos se transformem em criadores de sentidos" (ROJO e MOURA, 2012, p. 29).

A Pedagogia dos Multiletramentos nos apresenta uma forma crítica de ensino e aprendizagem, por meio dos elementos apresentados, de modo que o estudante (e/ou leitor) participa de forma efetiva dos processos de letramento vivenciados por eles em diversos eventos e práticas discursivas. A partir desses quatro elementos elaborados pelo GNL, sintetizo abaixo as competências de um leitor multiletrado, explicadas por Rojo e Moura (2012):

Figura 2 - Diagrama dos Multiletramentos proposto pelo Grupo de Nova Londres

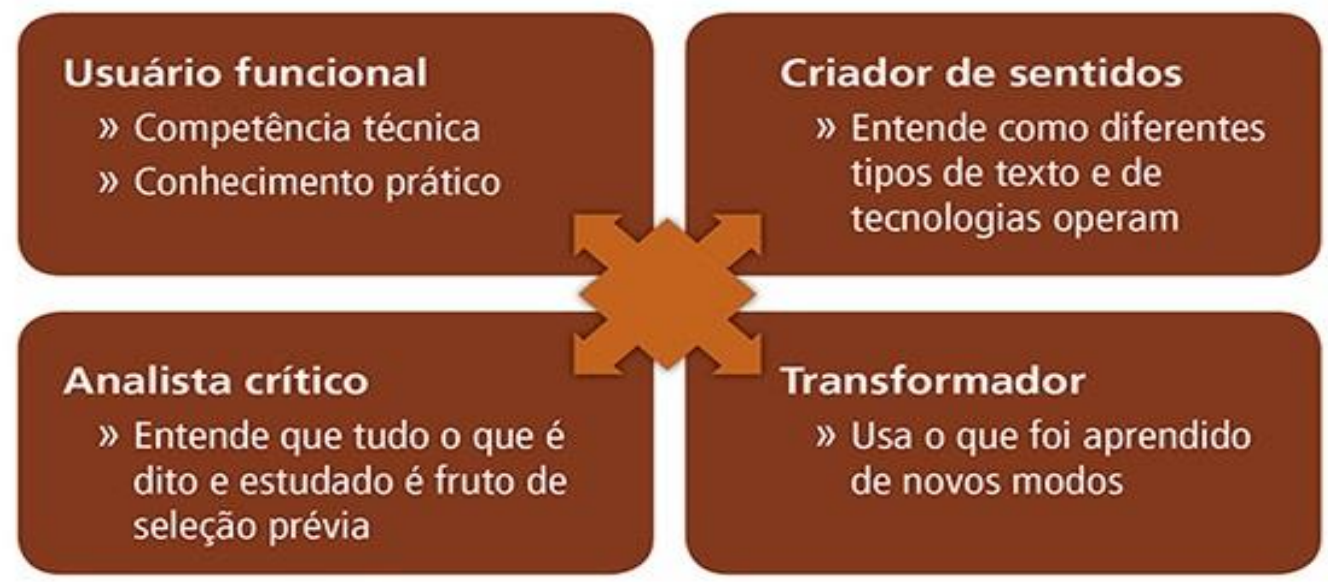

Fonte: Rojo e Moura (2012, p. 29).

\footnotetext{
${ }^{13} \mathrm{O}$ termo alfabetismos aqui se refere a letramentos.
} 
Os quatro elementos da Pedagogia dos Multiletramentos são complementares e foram elaborados de forma a apresentar uma proposta crítica, a partir de práticas de letramento, que abrange contextos diversos (inclusive o contexto escolar) para proporcionar autonomia ao estudante para recriar o que foi aprendido e compreender esses aprendizados nos demais contextos, utilizando tecnologias e reconhecendo formas distintas de buscar teorias e transformá-las em prática.

Quanto às práticas de Multiletramentos no ambiente escolar, elas ${ }^{14}$ : “[...] têm que se envolver com as experiências e discursos dos alunos, que são cada vez mais definidos pela diversidade cultural e subcultura e os diferentes contextos e práticas linguísticas [...]" (COPE e KALANTZIS, 2000, p. 36). Os estudantes devem assumir sua autonomia de aprendizagem, que precisa ser inserida em suas práticas sociais, assim eles poderão vivenciar melhor o que estão aprendendo por meio de experiências próprias. Os autores relatam que os Multiletramentos criam uma pedagogia diferente, pois a linguagem e os modos de significado tornam-se recursos representativos dinâmicos, sendo utilizados para alcançar diversos fins culturais. Afirmam ainda que ${ }^{15}$ :

[...] o argumento de Multiletramentos sugere a necessidade de um processo aberto e flexível da Gramática funcional que auxilie os alunos a descrever as diferenças linguísticas (culturais, subculturais, regionais/nacionais, técnicas, específicas do contexto, etc.) e os canais multimodais de significado agora tão importantes para a comunicação. (COPE e KALANTZIS, 2000, p. 6)

Dessa forma, os Multiletramentos envolvem práticas multimodais, visto que a Multimodalidade está presente em diversas formas de comunicação e informação textuais em livros, revistas, jornais impressos; ou em notícias on-line; ou em propagandas e programas de televisão; ou em sites e redes sociais.

Durante as discussões feitas pelo Grupo de Nova Londres, os pesquisadores desenvolveram uma teoria com seis elementos de design para o processo de criação de

\footnotetext{
14 Tradução minha do texto original: "Classroom teaching and curriculum have to engage with students' own experiences and discourses, which are increasingly defined by cultural and subcultural diversity and the different language backgrounds and practices [...]”. (COPE e KALANTZIS, 2000, p. 36)

15 Tradução minha do texto original: "[...] the Multiliteracies argument suggests the necessity of an openended and flexible functional grammar which assists language learners to describe language differences (cultural, subcultural, regional/ national, technical, context-specific, and so on) and the multimodal channels of meaning now so important to communication”. (COPE e KALANTZIS, 2000, p. 6)
} 
significados ${ }^{16}$ : “[...] o sentido linguístico, o sentido visual, o sentido auditivo, o sentido gestual, o sentido espacial e os padrões multimodais de significados que se relacionam com os cinco primeiros modos" (COPE e KALANTZIS, 2000, p. 7). Para ilustrar esses modos de significado que envolvem os Multiletramentos e a Multimodalidade, apresento a figura seguinte:

Figura 3 - Modos de Significado ${ }^{17}$

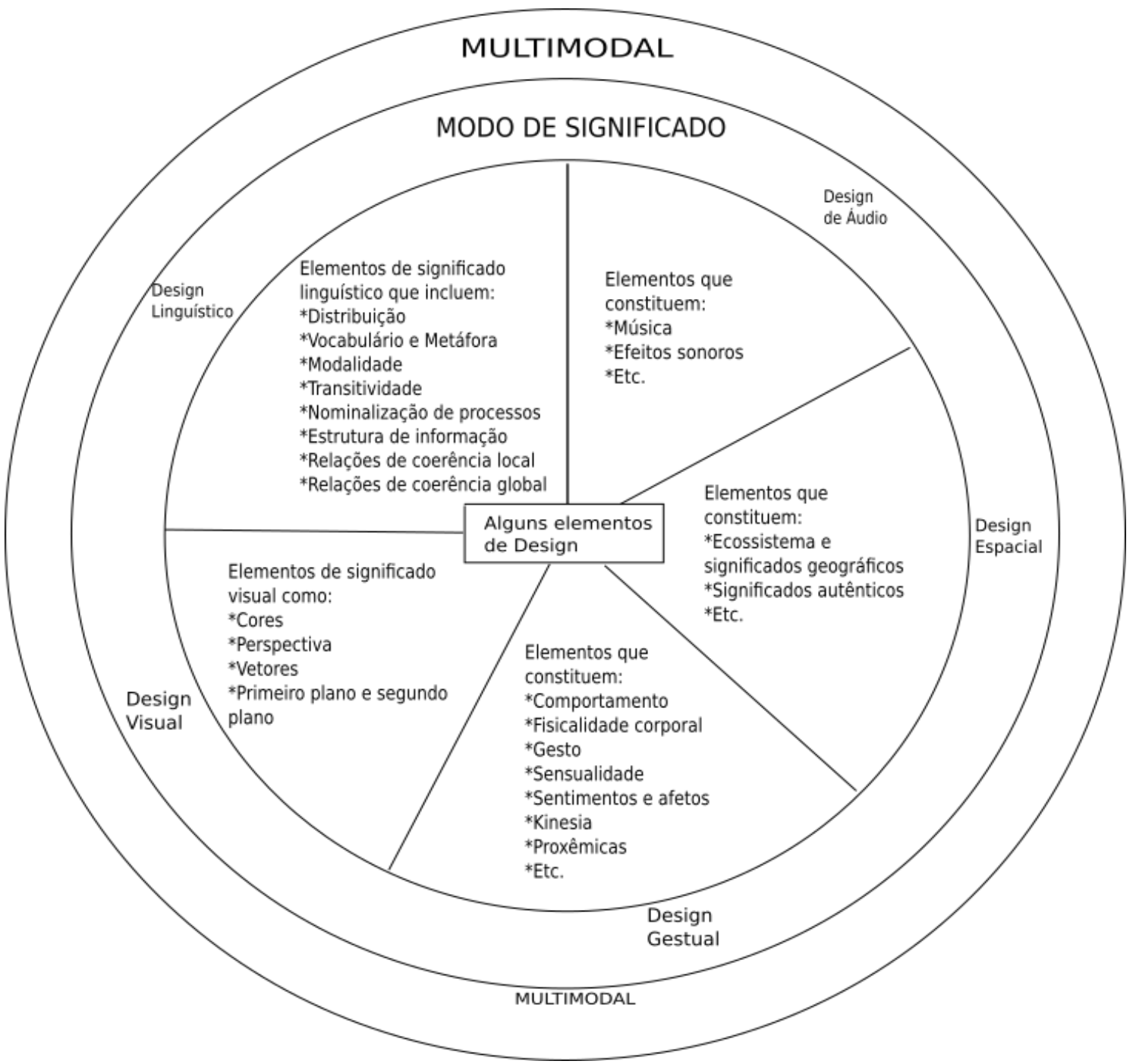

Fonte: Cope e Kalantzis (2000, p.26).

16 Tradução minha do texto original: “[...] Linguistic Meaning, Visual Meaning, Audio Meaning, Gestural Meaning, Spatial Meaning, and the Multimodal patterns of meaning that relate the first five modes of meaning to each other". (COPE e KALANTZIS, 2000, p. 7).

17 Tradução da própria autora. 
O termo design é entendido aqui como conjunto de significados, modelo de práticas discursivas e sociais a ser seguido, o qual pode ser melhor realçado, nesta pesquisa, nas práticas de letramento escolar. Sendo assim, os seis elementos citados acima compõem o design (modo de significado), podendo ser mais ou menos significativos, o que pode ser determinado pelo evento ou pela prática discursiva analisados.

Para Cope e Kalantzis (2000), o conceito de design envolve representação e recontextualização, desenvolvidas dentro das funções de design, apresentadas por Halliday (1978) - ideacional (por meio dos conhecimentos práticos), interpessoal (por meio das relações sociais) e textual (por meio das identidades). A relação de significados do texto é explicada pelas inter-relações entre os modos de significado (design) percebidas no texto pelos seus elementos de significado que se complementam.

A figura 3 representa então as relações de significados que podem aparecer em um mesmo texto. Desse modo, em um texto multimodal com variadas semioses (como é o caso do corpus desta pesquisa), pode haver mais de um modo de significado que, ao se relacionarem, dão sentido aos significados textuais através dessa inter-relação de significados.

Como o meu corpus são questões com textos multimodais do Enem, observo a presença mais destacada de apenas alguns desses elementos, conforme suas ocorrências: o design linguístico e o visual, por exemplo, são evidenciados; enquanto o auditivo, o espacial e o gestual são ignorados, pelo fato de o corpus ser composto por textos multimodais escritos. Assim sendo, de acordo com as características e tipos de cada texto, será possível encontrar mais ou menos modos de significado.

Nos textos multimodais desta pesquisa, os modos de significado dos textos serão compostos por seus elementos de significado (apresentados na figura 3): design linguístico - distribuição, vocábulo e metáfora, modalidade, transitividade, nominalização de processos, estrutura de informação, relações de coerência local e global; e design visual - cores, perspectiva, vetores, primeiro e segundo plano. Isso não garante que todos os elementos de cada design devem estar presentes ao mesmo tempo, esse fator dependerá do tipo de texto multimodal e de sua intenção de sentidos. 
O conceito de Designs de sentidos, ou de modos de significados, para Bevilaqua (2013, p.106), é o que estrutura a teoria dos Multiletramentos, visto que é por meio do design de sentidos que "[...] a teoria instanciará concepções de construção de sentido, interesse, agenciamento e multimodalidade, primordiais para o ensino requerido na contemporaneidade".

Para complementar a relação dos designs de sentidos com o letramento e a multimodalidade, Trajano (2013, p.167) argumenta que a compreensão de um texto modal “[...] passa por diferentes estágios de letramento, uma vez que, ao ser constituído por diferentes semioses, diferentes leituras também devem ser feitas [...]". Assim entendo que, quando há diversos modos de significado em um mesmo texto, a compreensão textual é ampliada, o que ocorre no Enem, por exemplo, pois o leitor interpreta de acordo com sua carga de leitura adquirida durante a vida, trazendo sua vivência sociocultural de leitura. Por isso, mais uma vez, destaco a relevância deste trabalho ao pesquisar os tipos de textos multimodais nas questões do Enem e a composição dos seus significados, bem como a análise de práticas de multiletramentos e de habilidades de leitura requeridas para a compreensão das questões.

Portanto, é preciso levar em consideração cada modo de significado nos textos multimodais, visto que eles produzem uma cadeia de sentidos formada pelas escolhas feitas pelo indivíduo, juntamente com fatores sociais, culturais e econômicos. Em se tratando desses fatores ligados às diferentes leituras, Kress e van Leeuwen (2006, p. 36) relatam ${ }^{18}$ :

As novas realidades da estrutura semiótica são provocadas por fatores sociais, culturais e econômicos: pela intensificação da diversidade linguística e cultural dentro dos limites dos estados da nação; pelo enfraquecimento desses limites dentro das sociedades, devido ao multiculturalismo, à mídia eletrônica de comunicação, às tecnologias de transporte e aos desenvolvimentos econômicos globais.

Com a inserção de estruturas multissemióticas na comunicação atual, as práticas de letramento se transformaram em intersemióticas, exigindo leitores e produtores de

\footnotetext{
${ }^{18}$ Tradução da própria autora do texto original: "The new realities of the semiotic landscape are brought about by social,cultural and economic factors: by the intensification of linguistic and cultural diversity within the boundaries of nation states; by the weakening of these boundaries within societies, due to multiculturalismo, electronic media of communication, technologies of transport and the global economic developments". (KRESS e VAN LEEUWEN, 2006, p. 36)
} 
textos "antenados" com o mundo tecnológico, atualizados com as tecnologias e mídias mais recentes.

Considerando o público-alvo do Enem e as questões atuais que abordam tecnologia, ainda observo que muitos estudantes não estão preparados para desenvolver práticas de letramento intersemióticas, isso porque muitos ainda não têm acesso à internet e/ou a outras mídias e a bibliotecas que ofereçam diversos tipos de leituras, o que pode prejudicar o contato com textos multissemióticos. Em vista disso, ressalto que esses pontos citados podem ser alguns dos problemas que dificultam a compreensão de questões multissemióticas como as das provas do Enem.

Sobre a ampliação contínua de acesso às tecnologias digitais da comunicação e informação, Rojo (2008, p. 583-584) aponta três mudanças importantes:

a) a intensificação vertiginosa e a diversificação da circulação da informação nos meios de comunicação analógicos e digitais, que, por isso mesmo, distanciam-se hoje dos meios impressos, muito mais morosos e seletivos, implicando, segundo alguns autores (CHARTIER, 1997; BEAUDOUIN, 2002), mudanças significativas nas maneiras de ler, de produzir e de fazer circular textos nas sociedades;

b) a diminuição das distâncias espaciais - tanto em termos geográficos, por efeito dos transportes rápidos, como em termos culturais e informacionais, por efeito da mídia digital, desenraizando as populações e desconstruindo identidades, e a diminuição das distâncias temporais ou a contração do tempo, determinadas pela velocidade sem precedentes, pela quase instantaneidade dos transportes, da informação, dos produtos culturais das mídias, características que também colaboram para mudanças nas práticas de letramentos;

c) a multissemiose que as possibilidades multimidiáticas e hipermidiáticas do texto eletrônico trazem para o ato de leitura: já não basta mais a leitura do texto verbal escrito - é preciso colocá-lo em relação com um conjunto de signos de outras modalidades de linguagem (imagem estática, imagem em movimento, fala, música) que o cercam, ou intercalam ou impregnam; esses textos multissemióticos extrapolaram os limites dos ambientes digitais e invadiram também os impressos (jornais, revistas, livros didáticos).

Pensando nos estudantes que precisam estar atualizados e preparados para a compreensão de textos diversos, utilizo as palavras de Kleiman (2014, p. 88) para acentuar que o estudante precisa “[...] desenvolver estratégias de acesso à informação e traçar os caminhos que fazem sentido para ele". Quanto ao agente de letramento, que, no contexto do Enem, pode ser um professor, consideramos que ele deve orientar "[...] o 
trabalho do aluno fornecendo materiais relevantes e modelos de atividade significativas" (KLEIMAN, 2014, p. 88).

No processo de ensino e de aprendizagem, professor e estudante devem se atualizar e acessar textos que envolvem diversas semioses e que estão em variados meios, inclusive nas mídias digitais. O professor, como pesquisador, tem de buscar essas leituras contemporâneas para despertar ainda mais em seus estudantes, nativos digitais, o interesse por elas.

Como o meu corpus são as questões do Enem, não posso deixar de abranger, nos capítulos deste trabalho, o tema "ensino", ou alguns elementos que são partes fundamentais desse processo, como estudantes, professores, aprendizagem, etc. Por isso, os insiro, no próximo tópico, em que trato dos Multiletramentos e da Multimodalidade no contexto do ensino.

\subsubsection{Multiletramentos e Multimodalidade no Ensino}

Ao trazer os multiletramentos e a multimodalidade para o nosso objeto de análise, percebemos que, no Enem, é relevante a presença de textos diversificados e multimodais, por se tratar de um exame contextualizado, unificado e interdisciplinar. Assim, há a necessidade de se trabalhar esses tipos de texto no ambiente escolar, para que o estudante estabeleça um contato diário com a leitura multimodal e esteja apto a compreendê-la de forma global e por meio de diversos modos de leitura.

Em uma de suas obras, Barton (1994), em consonância com Ivanič e Hamilton (1989 apud BARTON, 1994), apresenta uma lista de sugestões quanto à abordagem do letramento na escola, com questões relacionadas ao currículo, ao diagnóstico e à avaliação, e algumas relativas à ligação casa-escola. Abaixo apresento-a com adaptações, com base nos Letramento Cognitivo e Sociocultural e nos Multiletramentos:

1. O letramento escolar deve ser desenvolvido não só pela forma verbal impressa, mas por variadas semioses, incluindo a linguagem falada, a comunicação física, gráficos, etc.

2. Os professores devem explorar criticamente o letramento extraescolar, aproveitando o contexto em que os alunos vivem para que eles vivenciem verdadeiramente os multiletramentos dentro e fora da escola. 
3. A escola é um contexto por meio do qual se aprendem vários outros, visto que os estudantes, muito antes de iniciarem sua vida escolar, têm contato com o letramento informal.

4. Dentre os propósitos reais da escola, estão os de ler e escrever, entretanto eles não podem ser os únicos, as práticas sociais e culturais de letramento também são fundamentais.

5. As práticas de letramento diárias envolvem colaboração e uso de redes de suporte, podendo também ser desenvolvidas como prática de leitura e escrita colaborativa na sala de aula.

6. Os professorem devem levar em consideração que há pessoas que passaram pelo sistema escolar, mas não aprenderam a ler e escrever muito bem, e analisar que práticas pedagógicas podem ser inseridas para que essas pessoas desenvolvam a leitura e a escrita. Para isso, devem inserir experiências 'reais' na sala de aula, e não apenas utilizá-las de forma artificial com textos recortados e descontextualizados, por exemplo.

7. Os estudantes podem refletir por conta própria sobre outras práticas de letramento, observando, por exemplo, seus familiares, vivenciando etnograficamente esse processo e fazendo parte dele.

8. As avaliações de larga escala sobre a leitura e a escrita devem ser mais cautelosas, de forma que não sejam meramente quantitativas, deixando suas especificidades para os professores, que acompanham mais de perto esses processos, ou até mesmo para as autoavaliações dos próprios estudantes, de maneira que proporcionem autonomia de aprendizagem.

9. Os professores devem ser cautelosos ao aplicar testes, para que não se empregue neles um letramento isolado e descontextualizado.

10. Os erros na leitura e na escrita devem ser analisados, pois eles acontecem por determinadas razões. Os erros devem ser vistos como motivos de aprendizagem.

11. As práticas de letramento marginalizadas e/ou fora do domínio educacional precisam ser consideradas para que se evite ou diminua os índices de rejeição do letramento escolar pelos estudantes.

12. "O sistema educacional precisa permitir aos professores saber com que as crianças estão familiarizadas em casa e estar disposto a mudar as práticas 
escolares quando necessário” (BARTON,1994, p. 212), por isso é necessário que haja uma troca de informações entre a família e a escola.

13. "As escolas devem investigar quais práticas comunitárias devem ser legitimadas, integrando-as nas salas de aula" (BARTON,1994, p. 212), incluindo também as novas tecnologias e outros elementos que constituem o cotidiano dos estudantes, para que eles não se sintam excluídos quanto às suas próprias práticas de letramento.

Para formar indivíduos letrados e para a promoção eficaz da leitura e da escrita, é preciso investir em multiletramentos que atendam às exigências no atual contexto social quanto ao uso de tecnologias e de múltiplas semioses. Para que a escola possibilite aos alunos essas práticas sociais da leitura e da escrita de forma ética, crítica e democrática. Segundo Rojo (2008, p. 585), é necessário levar em consideração:

a) os multiletramentos ou letramentos múltiplos, também de maneira ética e democrática, deixando de ignorar ou apagar os letramentos das culturas locais de seus agentes (professores, alunos, comunidade escolar) e colocando-os em contato com os letramentos valorizados e institucionais; como diria Souza Santos (2005), assumindo seu papel cosmopolita;

b) os letramentos multissemióticos exigidos pelos textos contemporâneos, ampliando a noção de letramento para o campo da imagem, da música, das outras semioses e sistemas de signos que não somente a escrita alfabética, como já prenunciava, por exemplo, a noção de "numeramento"; o conhecimento de outros meios semióticos está ficando cada vez mais necessário no uso da linguagem, tendo em vista os avanços tecnológicos: as cores, as imagens, os sons, o design etc., que estão disponíveis na tela do computador e em muitos materiais impressos, que têm exigido outros letramentos, por exemplo, o letramento visual [...].

Assim, estou considerando que os letramentos são “[...] atos socioculturais concretos constituídos por pelo menos uma das seguintes atividades: leitura, escrita e fala ao redor ou sobre um texto escrito, bem como outros modos semióticos [...]" (RIOS, 2016, p. 55). Por conseguinte, os Multiletramentos e a Multimodalidade estão lado a lado em se tratando de elementos que facilitam a compreensão textual e a busca por leitura atualizada.

Em consonância com Rios (2016), Vieira et al (2007, p. 24) explicam que "O letramento típico da pós-modernidade agrega ao texto escrito inúmeros recursos gráficos, cores e, principalmente, imagens [...]", portanto eles exigem um "sujeito 
letrado" com habilidades básicas de interpretação utilizadas em suas práticas discursivas diárias. Esses pesquisadores dialogam que as mudanças no cenário da linguagem demandam "[...] alterações profundas nas formas de letramento" (VIEIRA ET AL, 2007, p. 24), que devem se estender, principalmente, ao recinto de aprendizagem escolar.

Quanto ao contexto de ensino e de aprendizagem (o ambiente escolar), Lorenzi e De Pádua (2012 apud TRAJANO, 2013, p. 172) argumentam que os textos multimodais “[...] trazem o significado não apenas na modalidade escrita, mas em todas as modalidades. A aprendizagem se dá em um novo ambiente de comunicação, em que a verdadeira língua/ linguagem aparece/ acontece". Os autores consideram as propostas multimodais eficazes na comunicação, pois elas estão muito além da escrita e fortalecem a linguagem. Com as novas tecnologias e o surgimento de outras modalidades semióticas, as imagens passam a fazer parte dos textos, não apenas com valor ilustrativo, mas como parte discursiva do texto escrito ou falado, com forte carga semântica e simbólica. Sobre a presença dessas modalidades em contínua transformação, Rojo e Moura (2012, p. 76) expressam que:

Tais modalidades passaram a exigir do leitor - no caso escolar, do aluno e do(a) professor(a) - a aquisição e o desenvolvimento de outras habilidades de leitura e escrita, dependendo das modalidades utilizadas, ampliando a noção de letramentos para múltiplos letramentos.

$\mathrm{Na}$ medida em que textos multimodais foram se disseminando no meio social, tornou-se primordial apresentar essas modalidades para os estudantes, por meio de texto em jornais, em revistas, em livros didáticos, em sites, em livros de literatura, e assim por diante. Foi-se inserindo no ensino textos que estabelecem variadas formas de compreensão e que inferem conhecimentos de diversos temas, assim como nas provas do Enem, em que se observam questões interdisciplinares.

Sobre o contato dos estudantes com textos multimodais, Kress e van Leeuwen (2006) argumentam que, no início do processo de aprendizagem na escola, as crianças produzem livremente várias atividades com desenhos, entretanto elas não são questionadas quanto às interpretações. Contudo, conforme vão avançando nas etapas escolares, as imagens continuam presentes, seja em forma de mapas, ou diagramas, ou outras ilustrações, mas elas vão atingindo um nível mais alto de compreensão, um nível 
especializado: ${ }^{19}$ "Em outras palavras, as imagens não desapareceram, mas tornaram-se especializadas em suas funções" (KRESS e VAN LEEUWEN, 2006, p. 16). Os autores consideram que ${ }^{20}$ :

Seja na mídia impressa ou eletrônica, seja em jornais, revistas, CDROM ou sites, seja como materiais de relações públicas, propagandas ou como materiais informativos de todos os tipos, a maioria dos textos agora envolve uma interação complexa de texto escrito, imagens e outros gráficos ou elementos sonoros, construídos como entidades coerentes (muitas vezes em primeiro nível, visual e não verbal), por meio do layout. Mas a habilidade de produzir textos multimodais deste tipo, por mais importante que seja seu papel na sociedade contemporânea, não é ensinada nas escolas. Discutindo duramente esse ponto, nos termos dessa nova e essencial habilidade de comunicação, este novo "letramento visual", educação institucional, sob a pressão de demandas políticas muitas vezes reacionárias, produz analfabetos. (KRESS e VAN LEEUWEN, 2006, p. 17).

Ainda tratando do contexto escolar, Trajano (2013) revela que as práticas multimodais estão diretamente relacionadas aos multiletramentos. Sobre o mesmo aspecto do tema, Garcia et al (2012 apud TRAJANO, 2013) relatam que há "[...] pesquisadores que fazem uso dos multiletramentos em escolas brasileiras com objetivo de enriquecer o repertório de seus alunos, tornando-os leitores mais críticos de gêneros discursivos".

Considerando os pontos de vista dos pesquisadores apresentados, destaco que é preciso que se insiram mais textos multimodais e, consequentemente, práticas de multiletramentos para formação de leitores atualizados e "familiarizados" com diversos tipos de texto. Com a difusão das tecnologias no cotidiano dos estudantes, a escola deve abordar multiletramentos, para isso é imprescindível que use textos multissemióticos apresentados inclusive por meios digitais.

Com a mudança discursiva na conjuntura atual, os educadores precisam repensar suas práticas pedagógicas, incluindo adequadamente novos recursos de forma ativa e

19 Tradução minha do texto original: "In other words, images did not disappear, but they became specialized in their function" (KRESS e VAN LEEUWEN, 2006, p. 16).

20 Tradução minha do texto original: "Whether in the print or eletronic media, whether in newspapers, magazines, CD-ROMs or websites, whether as public relations materials, advertisements or as informational materials of all kinds, most texts now involve a complex interplay of written text, images and other graphic or sound elements, designed as coherent (often at the first level visual rather than verbal) entities by means of layout. But the skill of producing multimodal texts of this kind, however central its role in contemporary society, is not taught in schools. To put this point harshly, in terms if this essential new communication ability, this new 'visual literacy', institutional education, under the pressure of often reactionary political demands, produces illiterates”. (KRESS e VAN LEEUWEN, 2006, p. 17). 
eficaz, para formar cidadãos letrados e habilitados às atuais leituras multissemióticas. Para detalhar um pouco mais essas habilidades, irei discuti-las a seguir.

\subsubsection{Habilidades de Leitura para Textos Multimodais}

Os textos multimodais requerem maior atenção para sua leitura e compreensão, visto que eles são compostos por diversas modalidades e todas elas devem ser observadas para uma interpretação eficaz. Sobre esse ponto, para Kress (2000, p. 196), qualquer gramática, independente da modalidade da língua, deve atender a três demandas de comunicação ${ }^{21}$ : “[...] comunicar sobre eventos e estados de assuntos no mundo; comunicar sobre as relações sociais dos participantes em uma interação comunicacional; e ter a capacidade de formar entidades internamente coerentes mensagens".

Kress (2000) defende a ideia de que tanto a língua escrita quanto a língua falada devem ser consideradas, em qualquer caso, multimodais. $\mathrm{O}$ autor reafirma que o idioma em si é um fenômeno multimodal, assim sendo, para descrever aqui as habilidades de leitura, considero as observações de Kress (2000) sobre todo texto ser multimodal.

Em se tratando de leitura, as habilidades, segundo Barton (1994, p. 196), podem ser consideradas como uma "visão autônoma de letramento", uma realização individual. O pesquisador ressalta que 22 “...] a leitura é um conjunto de habilidades que podem ser divididas em partes ensinadas e testadas" (BARTON, 1994, p. 196). Assim, conforme a prática de leitura, as habilidades vão sendo alinhadas de acordo com o grau de dificuldade do texto e das modalidades lidas.

Quanto à compreensão textual, conforme Byrne (2013, p. 129), “[...] Leitura (compreensão) é igual à Decodificação multiplicada por Linguagem (compreensão)”. Entendo que, quanto mais o indivíduo tiver acesso à leitura diversificada, mais ele adquirirá as habilidades de compreensão, assim elas podem ser aperfeiçoadas se ele tiver práticas de leituras mais "desenvolvidas" ou "avançadas” quanto às modalidades, por exemplo.

\footnotetext{
${ }^{21}$ Tradução da própria autora do texto original: "to communicate about events and states of affairs in the world; to communicate about the social relations of the participants in a communicational interaction; and to have the ability to form internally coherent entities - messages". (KRESS, 2000, p. 196)

22 Tradução da própria autora do texto original: “[...] reading is a set of skills which can be broken into parts an taught and tested”. (BARTON, 1994, p. 196)
} 
Para complementar a citação de Byrne (2013), Marcuschi (2008, p. 231) salienta: "Compreender [...] é muito mais uma forma de inserção no mundo e um modo de agir sobre o mundo na relação com o outro dentro de uma cultura e uma sociedade"; por isso é necessário que haja uma exposição substancial à leitura nos diversos meios sociais em que os leitores vivem - em casa, na igreja, na rua, no trabalho, na escola, etc.

Além dos meios sociais, Philips e Lonigan (2013) acreditam que o status econômico - juntamente com educação, valores, crenças, cultura, renda - influencia diretamente nas práticas de letramento e, consequentemente, na compreensão da leitura.

Sobre as habilidades de leitura adquiridas pela convivência com textos multimodais e pela prática de multiletramentos, Perfetti et al (2013, p. 246) determinam que a compreensão ocorre a partir de uma representação mental feita pelo leitor por meio de processos de compreensão em diversas unidades de linguagem: “[...] no nível da palavra (processos lexicais), no nível da sentença (processos sintáticos) e no nível do texto [...]", considerado aqui no sentido mais amplo como texto multimodal. Perfetti et al (2013, p. 264-265) complementam que:

- A experiência com a leitura aumenta a capacidade geral de compreensão.

- A compreensão da leitura e da escuta está relacionada e uma afeta potencialmente a aquisição de habilidades da outra.

- A compreensão da leitura pode se aproximar da capacidade da compreensão da escuta.

- O conhecimento do significado das palavras é fundamental para a compreensão.

- "Níveis mais elevados de compreensão exigem que o leitor aplique um padrão elevado de coerência ao seu entendimento do texto" (PERFETTI ET AL, 2013, p. 265). Nesse quesito, sugiro que a prática da leitura multimodal e multiletrada eleva esse nível.

As contribuições de Perfetti et al (2013) remetem à importância das práticas de letramentos - incluindo as multimodais, em diversos meios sociais, ao incentivo da leitura desde criança pela família e pelos professores, e à aquisição da prática diária da leitura. Quanto à leitura multimodal, Hodge e Kress (1991, p.130) afirmam²

\footnotetext{
${ }^{23}$ Tradução da própria autora do texto original: "In a common-sense view, 'realism' in the visual code corresponds to 'truth' in verbal code: a realistic visual represetation also likely to be seen as true. This is where the visual code has a large advantage over the verbal code". (Hodge e Kress, 1991, p.130)
} 
Em uma visão de senso comum, o "realismo" no código visual corresponde à "verdade" no código verbal: uma representação visual realista que também provavelmente seria vista como verdadeira. É aqui que o código visual tem uma grande vantagem sobre o código verbal.

Ao comparar o texto verbal com o texto visual, é perceptível como esse segundo, de forma geral, chama mais atenção do leitor, por permitir, possivelmente, uma leitura mais dinâmica e realista, proporcionando uma proximidade e tornando o assunto mais agradável e, como relataram Hodge e Kress (1991), mais real.

Ainda sobre o letramento visual, Kleiman (2014, p. 82), concordando com Dondis (1973 apud Kleiman, 2014), discorre que:

\begin{abstract}
Quando a capacidade de interpretar e expressar-se por meio da modalidade visual icônica é desenvolvida, são desenvolvidos critérios que vão além tanto das nossas capacidades intuitivas ou inatas, comuns a todos, para interpretar imagens quanto dos gostos individuais e das preferências pessoais condicionadas pelo contexto, pelo modismo, por restrições socioeconômicas. O conhecimento propicia interpretações baseadas num sentido de adequação e prazer estéticos e, por sua vez, esse nível de desenvolvimento cria autonomia, pois envolve tanto o domínio da modalidade, quanto o controle dos efeitos que ela é capaz de produzir. Quanto menos passivos e mais participativos os fruidores de textos multimodais e intersemióticos (dos multiletramentos), maiores as possibilidades de que a réplica à linguagem icônica envolva o uso da "inteligência visual" (DONDIS, 1973) [...].
\end{abstract}

Consoante as considerações acima, Vieira et al (2007, p. 29) asseveram que "[...] é mais difícil escaparmos da sedução dos textos imagéticos, manifestada pelo tamanho da imagem, pelo movimento, pela cor e pela beleza”. Estes pesquisadores argumentam que as imagens atraem a atenção do leitor e que podem ser, em alguns casos, mais facilmente compreendidas e memorizáveis, assim sendo, os leitores estão propensos a voltar mais sua atenção ao texto multimodal, e visual, que ao texto verbal.

Para um melhor entendimento sobre a compreensão geral de texto, Melo e Ribeiro (2004, p. 133) apresentam quatro formas de direcionamento que podem estar presentes durante a leitura e, levando em consideração as diversas habilidades do leitor, comento trazendo-as para o nosso objeto de análise - o Enem: 
1. Leitura busca-de-informações: é mais direcionada a responder à pergunta "para quê", ou seja, procura-se encontrar a informação desejada. É possível observá-la nos exames do Enem, visto que há muitas questões de compreensão textual que exigem do estudante um olhar mais atento sobre determinadas informações para responder perguntas sobre análise textual, interpretação, constituição de significados, etc.

11. Leitura estudo-de-texto: o objetivo é extrair do texto todas as possibilidades de compreensão e/ou várias informações. Esse tipo de leitura também é perceptível nas questões do Enem, pelo fato do referido exame conter textos interdisciplinares utilizados para responder várias questões.

III. Leitura do texto-pretexto: intenta buscar no texto elementos que auxiliem a organização de ideias, de argumentos, etc. Ela pode ser considerada nas questões do Enem que abordam interpretação textual, por exigir do leitor uma leitura mais atenta e subjetiva.

IV. Leitura fruição-do-texto: é uma leitura mais "descomprometida", é o ler por ler, por lazer, sem nenhum tipo de compromisso. No Enem, é possível que não haja essa modalidade de leitura, uma vez que os textos são voltados para questões avaliativas de que abordam os textos em perspectivas diferentes.

Ao analisar, mais uma vez, a compreensão de textos multimodais, Kress e van Leeuwen (2006) relatam que os modos semióticos dos textos dependem de especificidades relacionadas à cultura e à história, assim os textos podem se apresentar: nos modos verbal e visual; podem enfatizar um modo mais que o outro; ou podem se apresentar de um modo só - verbal ou visual. Quanto às habilidades para a compreensão dessas diversas modalidades, Vieira et al (2007, p. 24) defendem que:

Atualmente, as habilidades textuais devem acompanhar os avanços
tecnológicos, e a qualidade mais valorizada nos sujeitos do
letramento é a capacidade de mover-se rapidamente entre diferentes
letramentos. Por essa razão, as práticas textuais compõem-se de
diferentes linguagens semióticas, que podem abrigar a fala e a
escrita, a comunicação visual e sonora, além de utilizarem os
recursos computacionais e tecnológicos, cujo desempenho dos
autores deve ser competente tanto na produção como na
interpretação de textos de diferentes gêneros discursivos.

Em meio a tantos textos multimodais e multissemióticos, Vieira et al (2007, p. 25) reafirmam que o leitor deve ter mais preparo e conhecimento. Esse indivíduo deve “[...] não apenas se familiarizar com a multimodalidade textual, capaz de construir 
textos predominantemente imagéticos, como também construir aparato crítico que lhe permita lidar com essa nova realidade textual".

A compreensão textual é um processo que exige habilidade, interação e trabalho (MARCUSCHI, 2008). Por isso, o leitor, além de estar atento às modalidades textuais e aos multiletramentos, precisa estar verdadeiramente imerso socioculturalmente nas práticas de leitura para desenvolver habilidades linguística, cognitiva e sociocultural. Além disso, para uma compreensão textual eficaz, os conhecimentos compartilhados que o leitor traz em sua carga de leituras anteriores também são essenciais para a leitura de textos multimodais, dessa forma apresentarei alguns conceitos sobre esses conhecimentos no item que segue.

\subsubsection{Conhecimentos Extralinguísticos como Auxílio na Compreensão Textual}

Sobre a compreensão da leitura, Antunes (2003) afirma que ela depende do contexto linguístico do texto e do contexto extralinguístico, portanto as informações prévias são parte fundamental desse processo. A autora argumenta que:

O sentido de um texto não está apenas no texto, não está apenas no leitor. Está no texto e no leitor, pois está em todo o material linguístico que o constitui e em todo o conhecimento anterior que o leitor já tem do objeto de que trata o texto. É por isso que não se pode ver no texto o que lá não está nem se pode ver apenas o que lá está sobre a página. A leitura tem, assim, a dinâmica de qualquer outro encontro: seu sentido é de agora e de antes. (ANTUNES, 2003, p. 78).

No processo de compreensão, o leitor utiliza o conhecimento adquirido durante a vida: seu conhecimento prévio; assim sendo, Kleiman (1989, p. 13) relata que esse processo é interativo, o que envolve "[...] diversos níveis de conhecimento, como o conhecimento linguístico, o textual, o conhecimento de mundo [...]”. A autora completa que, sem o "engajamento" dos conhecimentos prévios do leitor, não seria possível uma compreensão efetiva, pois é por meio deles que o leitor faz inferências e relaciona diversas partes do texto para que se tornem coerentes.

Para complementar as contribuições de Kleiman (1989), Marcuschi (2008) sugere alguns conhecimentos que fazem parte do conhecimento prévio e que aqui insiro por observar neles traços sobre o letramento cognitivista e o sociocultural: 
conhecimentos linguísticos; conhecimentos factuais (enciclopédicos); conhecimentos específicos (pessoais); conhecimentos de normas (institucionais, culturais, sociais); conhecimentos lógicos (processos).

O conhecimento linguístico, o textual e o prévio - ou extralinguístico, devem estar interligados para a composição do significado do texto e para sua compreensão. Da mesma forma, os significados dos textos multimodais e as multissemioses também se completam, em cada evento ou gênero discursivo, constituindo uma complementaridade intersemiótica.

Os textos que serão analisados fazem parte de uma prática social comum provas avaliativas do Enem, lidas e respondidas por estudantes de níveis de escolaridade distintos, a partir do Ensino Médio; e, pela prática social, os textos exigem conhecimentos formais linguísticos e conhecimentos prévios para sua compreensão. Como os leitores das provas do Enem são um público diversificado (formandos do Ensino Médio, graduandos, graduados, pesquisadores, etc.), espera-se que eles tenham conhecimentos sobre textos multimodais por meio de multiletramentos vivenciados em seus cotidianos.

Após a apresentação de elementos teóricos que embasam este estudo, passo agora para questões metodológicas selecionadas de forma a orientar a continuidade desta pesquisa até chegar às possíveis conclusões. 


\section{CAMINHOS METODOLÓGICOS PARA UMA ANÁLISE MULTISSEMIÓTICA E MULTILETRADA}

Para o desenvolvimento deste trabalho, quanto à natureza, foi realizada uma pesquisa qualitativa - teórico-conceitual. Quanto aos meios de investigação, livros e sites da internet foram utilizados para a pesquisa de conceitos, para a busca das provas do Enem. Do ponto de vista dos procedimentos técnicos, utilizo pesquisa documental e pesquisa bibliográfica para, por meio da ADC, verificar a ocorrência de textos multimodais e os multiletramentos requeridos.

Em se tratando dos objetivos, na pesquisa exploratória, utilizo a matriz Linguagens, Códigos e suas Tecnologias do Enem para a seleção do meu corpus (as questões) para analisar, à luz das teorias de Multiletramentos e de Multimodalidade, quais os tipos de texto multimodal são abordados nessas questões. É importante frisar novamente que utilizarei textos que não requeiram conteúdos de áreas de conhecimento que não sejam de Língua Portuguesa e afins.

\subsection{Duas Vertentes de Pesquisa: Qualitativa versus Quantitativa}

Neste tópico, apresento alguns conceitos das abordagens qualitativa e quantitativa de pesquisa e diferenças entre elas para justificar a escolha pela abordagem qualitativa. Apesar disso, utilizei também, para a coleta dos textos das questões a serem analisadas, um levantamento de dados, em parte quantitativo, para chegar ao corpus final da análise.

Na pesquisa qualitativa, segundo Denzin (2006, p.32), o pesquisador coleta dados "[...] a partir de uma comunidade interpretativa distinta que configura, em seu modo especial, os componentes multiculturais, marcados pelo gênero, do ato da pesquisa". Esse é um tipo de pesquisa social, que envolve o meio sociocultural e suas influências, que insere o pesquisador no contexto de sua pesquisa.

Por outro viés, a pesquisa quantitativa é tomada de causalidades, excluindo, na medida do possível, outras influências. Segundo Flick (2013, p. 22), ela trabalha com números e tem ênfase na mensuração, assim, “[...] por meio da padronização da coleta dos dados e da situação da pesquisa, os critérios de confiabilidade, validade e objetividade podem ser satisfeitos”. Em consonância com Becker (1996 apud DENZIN, 
2006), Denzin (2006) aponta cinco aspectos significativos em que a pesquisa qualitativa difere da pesquisa quantitativa:

1. Usos do positivismo e do pós-positivismo: do ponto de vista positivista, há uma realidade para ser estudada, captada e compreendida; enquanto os pós-positivistas argumentam que a realidade não pode ser plenamente aprendida. Ao passo que a quantitativa é utilizada para reforçar "[...] certos tipos de dados, interpretações e para testar hipóteses através de amostras" (DENZIN, 2006, p. 24).

2. Aceitação das sensibilidades pós-modernas: a nova geração de pesquisadores qualitativos incluiu métodos alternativos como "[...] a verossimilhança, [...] a responsabilidade pessoal, a ética do cuidar, a práxis política, os textos de múltiplas vozes e os diálogos com sujeitos [...]" (DENZIN, 2006, p. 24), rejeitando métodos e suposições positivistas.

3. Formas de captar o ponto de vista do indivíduo: “[...] tanto os pesquisadores qualitativos quanto os quantitativos preocupam-se com o ponto de vista do indivíduo" (DENZIN, 2006, p. 24). Entretanto, os pesquisadores qualitativos podem observar melhor o ponto de vista do indivíduo por meio de entrevista e de observação mais detalhadas.

4. Exame das limitações do cotidiano: os pesquisadores qualitativos podem ir ao encontro do "mundo social cotidiano", inserindo nele suas ações e descobertas; enquanto os quantitativos buscam estudar uma ciência nomotética com base em probabilidades do estudo de grandes números.

5. Garantia da riqueza das descrições: os pesquisadores qualitativos dão valor a descrições ricas do mundo social; enquanto os pesquisadores quantitativos, pelos compromissos éticos, nomotéticos, são indiferentes a essas descrições, pois elas não fazem parte das generalizações.

Para diferenciar melhor essas duas perspectivas de pesquisa, exponho, abaixo, segundo Bauer e Gaskell (2000), um quadro comparativo que traz algumas características que são diferentes entre elas. 
Quadro 3-Quadro comparativo entre as abordagens de pesquisa

\begin{tabular}{|c|c|}
\hline Pesquisa Quantitativa & Pesquisa Qualitativa \\
\hline Generalização & Particularidade \\
\hline Evidências & Significados \\
\hline Confirmação & Compreensão \\
\hline Conexões lineares & Complexidade \\
\hline Amostras aleatórias & Amostras propositais \\
\hline Objetiva, estruturada & Subjetiva, flexível \\
\hline Extensa & Intensa \\
\hline Fenômenos mensurados & Relação dialética entre pesquisador e \\
& pesquisado \\
\hline Neutralidade do pesquisador & Intersubjetividade entre pesquisador e \\
& pesquisado \\
\hline
\end{tabular}

Fonte: a própria autora, com base em Bauer e Gaskell (2000).

Para o desenvolvimento deste trabalho, quanto à forma de abordagem do problema, realizo levantamento de dados por amostragem dos tipos textuais monomodais e multimodais, encontrados nas questões das provas dos cadernos de Linguagens e Códigos dos exames dos anos de 2009 (ano em que as matrizes de referência do Enem foram implantadas) a 2016. Nesta organização dos dados, utilizo a pesquisa quantitativa para, a partir do levantamento, selecionar as questões a serem analisadas.

Em cada questão, verifiquei se há texto motivador, texto multimodal e imagem. Para a seleção dos textos, não julguei como texto multimodal os textos verbais com destaque apenas para o título em negrito, por exemplo, por ser o padrão mais encontrado nos textos das provas observadas.

Das questões com textos multimodais, são analisadas, por meio da abordagem qualitativa, uma questão de cada primeira aplicação das provas das edições de 2009 a 2016 (totalizando oito questões) para verificar os tipos de multiletramentos que as perpassam, que textos multimodais estão presentes, e como eles se complementam para a compreensão textual. Selecionei questões variadas com temas diversos que tenham textos motivadores multimodais com mais de uma semiose evidente neles, sendo pelo menos uma delas imagem. O detalhamento da seleção das questões será melhor elucidado no item 4.1. 
Por se tratar de um trabalho que se fundamenta na ADC, que analisa questões de Multimodalidade e de Multiletramentos, e que versa sobre o contexto sociocultural e estrutural em que a pesquisa está inserida, optei por utilizar essencialmente a abordagem qualitativa, assim sendo, apresentarei algumas considerações sobre ela no tópico que segue.

\subsubsection{A Pesquisa Qualitativa na Pesquisa de Cunho Social}

Para Denzin (2006), a pesquisa qualitativa é uma forma de investigação que aborda disciplinas, campos e temas; constrói conceitos e suposições. Segundo o autor,

[...] a pesquisa qualitativa é uma atividade situada que localiza o observador no mundo. Consiste em um conjunto de práticas materiais e interpretativas que dão visibilidade ao mundo. Essas práticas transformam o mundo em uma série de representações, incluindo as notas de campo, as entrevistas, as conversas, as fotografias, as gravações e os lembretes. Nesse nível, a pesquisa qualitativa envolve uma abordagem naturalista, interpretativa, para o mundo, o que significa que seus pesquisadores estudam as coisas em seus cenários naturais, tentando entender ou interpretar, os fenômenos em termos dos significados que as pessoas a eles conferem. (DENZIN, 2006, p. 17)

A despeito disso, pode-se observar na pesquisa qualitativa de cunho social - e aqui inclusive pelas considerações da $\mathrm{ADC}$, que o pesquisador ressalta essas características naturalistas e interpretativas por estar inserido na pesquisa, por observar as práticas discursivas e sociais de determinada comunidade a que a pesquisa se relaciona.

Dessa maneira, para escolher as práticas da pesquisa, é preciso que se definam perguntas a partir do contexto de pesquisa (NELSON ET AL apud DENZIN, 2006, p. 18). Por isso, os autores defendem que a pesquisa qualitativa tem foco multiparadigmático, podendo ser interdisciplinar, transdisciplinar e, inclusive, contradisciplinar. Assim sendo, ela demanda um posicionamento ético e político, que inclui " [...] o mundo da experiência vivida, pois é nele que a crença individual e a ação e a cultura entrecruzam-se" (DENZIN, 2006, p. 22).

$\mathrm{Na}$ pesquisa qualitativa de cunho social, Denzin (2006) pressupõe que o pesquisador tenha as seguintes características: 
- Sensibilidade e curiosidade para o que é visível ou não visível de forma imediata; e empatia com os outros.

- "Habilidade de se desligar dos valores particulares e dos interesses especiais de grupos organizados a fim de adquirir um nível de compreensão que não dependa de compromissos a priori" (DENZIN, 2006, p. 49).

- Um pouco de distanciamento social e pessoal das normas e dos valores predominantes para que a análise seja realizada com objetividade.

A tarefa de pesquisa qualitativa social exige tanto o ato de observar quanto o de comunicar a análise dessas observações aos outros. Sobre a pesquisa qualitativa, Flick (2013, p. 25) relata:

Uma vantagem da pesquisa qualitativa é que uma análise detalhada e exata de alguns casos pode ser produzida, e os participantes têm muito mais liberdade para determinar o que é importante para eles e para apresentá-los em seus contextos. A desvantagem é que essas análises com frequência requerem muito tempo e só é possível generalizar o resultado para as massas amplas de uma maneira muito limitada.

Ao realizar este trabalho pautado na $\mathrm{ADC}$, pondero que a pesquisa qualitativa se torna requisito necessário para o seu desenvolvimento, visto que é uma análise detalhada que inclui as teorias dos Multiletramentos - que perpassam contextos diversificados, mesmo se tratando de um objeto de educação (questões de provas do Enem) -, e da Multimodalidade - que engloba textos com variadas semioses.

Para dar continuidade aos passos metodológicos, sigo então com as etapas desta pesquisa.

\subsubsection{As Etapas da Pesquisa}

A seguir apresento as etapas utilizadas para o desenvolvimento deste estudo: 
Quadro 4 - Etapas metodológicas e seus procedimentos

\begin{tabular}{|l|c|}
\hline \multicolumn{1}{|c|}{ Etapas } & Procedimentos \\
\hline Orientação Teórica & $\begin{array}{c}\text { Identificação do problema. } \\
\text { Revisão de literatura. }\end{array}$ \\
\hline Concepção de Ideias & $\begin{array}{c}\text { Planejamento da pesquisa. } \\
\text { Decisão dos métodos. }\end{array}$ \\
\hline Organização dos Dados & Coleta de dados por pesquisa bibliográfica. \\
& Análise de dados. \\
\hline Reflexão e Escrita & Escrita e reflexão sobre a relevância da pesquisa. \\
\hline Possíveis conclusões & Considerações ao final da pesquisa. \\
\hline Possíveis respostas & Intenção de apresentar considerações aos participantes \\
& indiretos após o final deste estudo. \\
\hline
\end{tabular}

Fonte: a própria autora, com base em Flick (2013).

A orientação teórica, que abrange a identificação do problema e a revisão de literatura, partiu da leitura cuidadosa das provas do Enem de cada ano após a minha própria experiência pessoal em 2006, quando realizei o exame. Observei que nelas havia textos bem diversificados e, então, dediquei maior atenção aos que continham imagens e outras semioses (como fontes, cores, etc.), assim direcionei o meu olhar para os textos Multimodais. Com a presença de textos com variados recursos semióticos, com o desenvolvimento diário e rápido da tecnologia e com a demanda dela nesses textos, vi a necessidade de incluir no estudo o olhar sobre os Multiletramentos.

A concepção de ideias e a organização dos dados trabalharam juntas. Foi quando optei pela abordagem qualitativa e defini os passos do meu trabalho; em seguida, selecionei o corpus de análise - oito textos multimodais de questões de provas do Enem, um texto de cada primeira aplicação a partir do ano de 2009 até 2016. Explicarei mais detalhadamente a seleção do corpus no item 4.1.

As possíveis conclusões podem ser consideradas flexíveis, visto que esta pesquisa pode ter continuidade futuramente ou por mudanças que, por ventura, venham a ocorrer no meu objeto de estudo - o Enem. Quanto às possíveis respostas, intento apresentá-las aos participantes indiretos deste estudo - aos estudantes que realizam as provas do Enem que tenham interesse em ler esta pesquisa ou artigos que produzi e pretendo produzir; e aos colaboradores do Inep que participam direta ou indiretamente no processo de elaboração desse exame pretendo apresentar futuramente o levantamento de dados realizado para se chegar ao corpus selecionado.

Também pretendo, por meio de produção de trabalhos científicos que contemplem textos multimodais e as habilidades de leitura das questões do Enem, 
incentivar docentes para o uso de textos diversificados no Ensino, visando uma reflexão dos docentes sobre a utilização da diversidade de textos e maior esclarecimento aos estudantes quanto à compreensão dos textos multimodais e melhor compreensão das questões do exame.

Finalizada esta parte, passo, portanto, para as definições relativas ao contexto da pesquisa.

\subsection{Contexto da Pesquisa}

Neste tópico, apresentaremos: o contexto da análise - o Enem; as categorias analíticas - pautadas nas teorias da Multimodalidade e dos Multiletramentos, e fundamentadas na ADC; e a proposta de análise de dados segundo as categorias que serão apresentadas.

\subsubsection{O Corpus da Análise}

O objeto deste estudo são questões de provas do Enem, selecionadas do caderno de questões "Linguagens, Códigos e suas Tecnologias" e que não demandam conhecimentos específicos de outras disciplinas que não seja a Língua Portuguesa e conhecimentos afins.

A partir de um levantamento de dados das questões da referida matriz das edições entre 2009 e 2016, oito questões com textos motivadores multimodais foram escolhidas para compor o corpus desta pesquisa - uma questão de cada edição das provas azuis; elas estão especificadas no quadro a seguir:

Quadro 5-Questões para análise

\begin{tabular}{|c|c|c|c|}
\hline Texto & Questão & Ano & Assunto \\
\hline Texto 1 & 105 & 2009 & Tecnologia (HTML) \\
Texto 2 & 132 & 2010 & Mentes masculina e feminina \\
Texto 3 & 97 & 2011 & Amizade pós-moderna \\
Texto 4 & 103 & 2012 & Rede social \\
Texto 5 & 131 & 2013 & O mundo conectado \\
Texto 6 & 131 & 2014 & Selfie \\
Texto 7 & 118 & 2015 & Prevenção da hepatite \\
Texto 8 & 109 & 2016 & Trânsito sem celular \\
\hline
\end{tabular}

Fonte: a própria autora. 
Para o corpus da pesquisa, selecionei questões com texto motivador que contenha mais de uma semiose evidente e, necessariamente, pelo menos uma imagem, pois intento analisar a contribuição da imagem no texto multimodal na composição dos significados, se ela se manifesta de forma que contribui com o sentido textual ou se ela é apenas um item de realce ou uma ilustração. Na seleção, ignorei os textos que continham apenas uma parte dele destacada em negrito ou em itálico, por exemplo, nesse caso, não o considerei, para o contexto deste trabalho, como texto multimodal, pois verifico que a ocorrência desse tipo de texto é muito recorrente nas questões das provas do Enem.

Entretanto, após a seleção, foi inevitável perceber que a maior parte dos textos motivadores escolhidos foi produzida no meio digital ou aborda tal assunto, contudo isso não foi proposital, pois a escolha das questões foi realizada de forma a evidenciar a diversidade de textos multimodais e as diversas habilidades de multiletramentos, para possibilitar uma análise que detalhe competências diferentes da multimodalidade e dos multiletramentos. Mesmo assim, penso que a escolha desse tipo de texto pode estar relacionada ao meu posicionamento, mesmo que inconsciente, sobre a importância das mídias digitais que popularizam e disseminam textos em tempo mínimo, o que possibilita sua disseminação para um público diverso, inclusive os candidatos que prestam as provas do Enem.

$\mathrm{Na}$ análise dos dados, abordarei algumas categorias dos Multiletramentos e da Multimodalidade orientadas pela Análise de Discurso Crítica, apresento-as no próximo tópico.

\subsection{As Categorias Analíticas}

As categorias relacionadas aos Multiletramentos, à Multimodalidade e à Gramática Visual são pautadas na ADC e formam uma tríade analítica, como ilustrado na figura abaixo. 
Figura 4 - Tríade Analítica

Multiletramentos

Análise de

Discurso Crítica

(ADC)

Multimodalidade

Gramática Visual

Fonte: a própria autora.

Assim sendo, para analisar a ocorrência de textos multimodais e as habilidades de leitura requeridas para a compreensão textual do meu objeto de estudo, utilizarei as áreas e os teóricos organizados da seguinte forma:

Quadro 6 - Métodos de análise

\begin{tabular}{|l|l|l|}
\hline Categorias & Teóricos & Finalidades \\
\hline Multimodalidade & $\begin{array}{l}\text { Kress e van Leeuwen } \\
(2006) \text {; Vieira (2010). }\end{array}$ & $\begin{array}{l}\text { Analisar que tipos de textos } \\
\text { multimodais estão presentes no } \\
\text { objeto de pesquisa. }\end{array}$ \\
\hline Gramática do Design Visual & $\begin{array}{l}\text { Kress e van Leeuwen (2001, } \\
\text { 2006). }\end{array}$ & $\begin{array}{l}\text { Analisar como os textos } \\
\text { multimodais são utilizados } \\
\text { para compor o sentido das } \\
\text { questões. }\end{array}$ \\
Multiletramentos & $\begin{array}{l}\text { Analisar como os } \\
\text { multiletramentos } \\
\text { abordados que habilidades de } \\
\text { leitura são requeridas para a } \\
\text { compreensão textual. }\end{array}$ \\
\hline
\end{tabular}

Fonte: a própria autora.

As categorias serão utilizadas de maneira que se alcancem os objetivos (finalidades) do trabalho. 


\subsubsection{Categorias da Gramática do Design Visual}

O objetivo da Gramática do Design Visual (GDV) é analisar a "sintaxe visual", é reunir "[...] as principais estruturas composicionais que têm se tornado convenções ao longo da história da semiótica visual e analisar como elas são usadas pelos produtores de imagem contemporâneos para produzir sentido" (KRESS; VAN LEEUWEN, 1996 apud VIEIRA e FERRAZ, 2011, p. 12). A figura abaixo apresenta a ênfase da Semiótica Social na comunicação visual, mais especificamente, na sintaxe visual.

Figura 5 - O enfoque da sintaxe visual na proposta da Semiótica Social

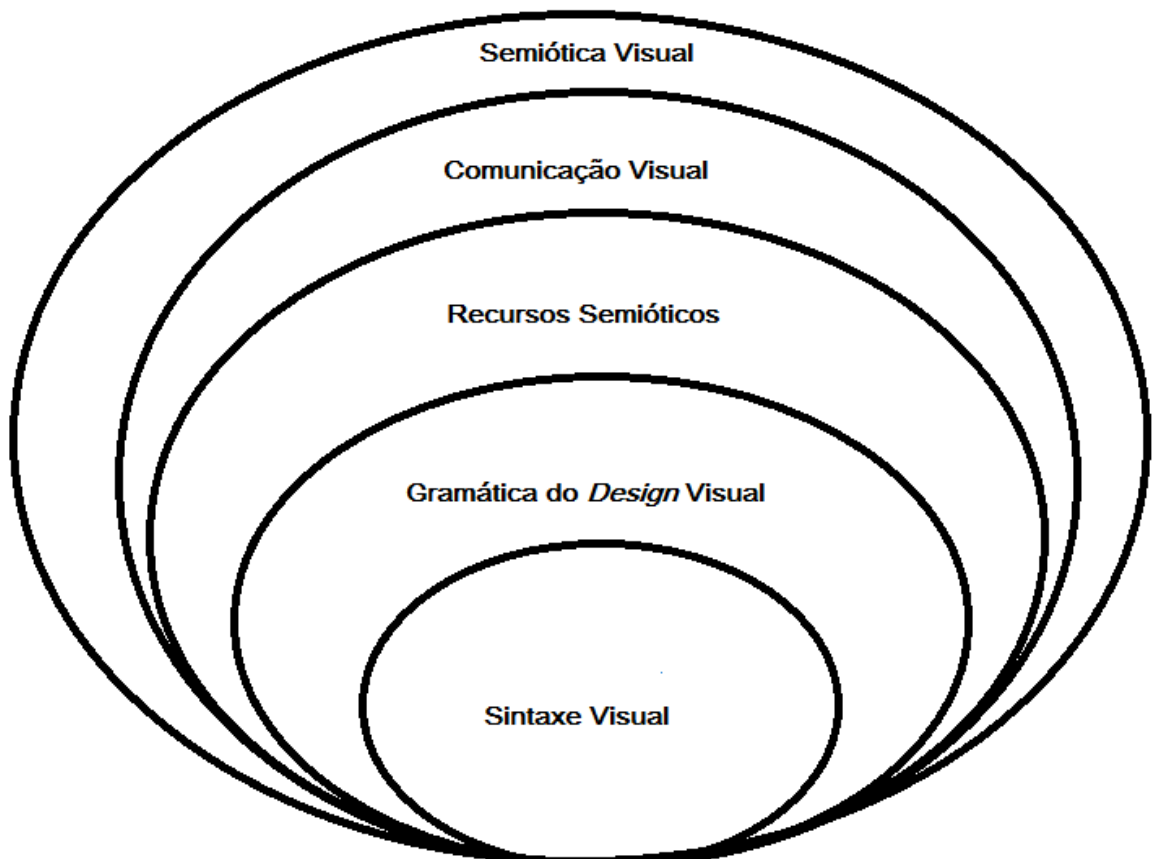

Fonte: Vieira e Ferraz $(2011$, p.13).

$\mathrm{Na}$ figura, a semiótica visual é composta por outros elementos que são hierarquizados entre eles, sendo o último a sintaxe visual. Para a análise deste trabalho, observo a semiótica visual na composição dos significados dos textos escolhidos - são recursos semióticos como texto verbal, figura, desenho, pintura, gráfico, infográfico, tabela, quadro, etc., que se relacionam para dar sentido ao texto. Em relação à comunicação visual, ela é realizada por meio da semiótica visual, com elementos que compõem o texto visual (os recursos semióticos).

Quanto à Gramática do Design Visual (GDV), Vieira e Ferraz (2011, p. 13) destacam que "O propósito da gramática do design visual é focalizar o processo de 
produção sígnica, compreendido como uma ação social realizada em determinado uso e contexto [...]". Para as autoras, o produtor do texto utiliza os modos semióticos mais apropriados para expressar o significado pretendido.

Sobre a comunicação visual, de acordo com Kress e van Leeuwen (2006, p. $2)^{24}$ : “Como estruturas linguísticas, as estruturas visuais apontam para interpretações particulares de experiências e formas de interação social. Até certo ponto, elas também podem ser expressas linguisticamente". Os autores explicam que a GDV trata do texto multimodal e seu objetivo é abordar " $[\ldots]$ as principais estruturas composicionais que têm se tornado convenções ao longo da história da semiótica visual e analisar como elas são usadas pelos produtores de imagem contemporâneos [...]” (KRESS e VAN LEEUWEN apud VIEIRA e FERRAZ, 2011, p. 12). A análise das estruturas do texto visual é realizada por meio da sintaxe visual, que analisa as funções de cada estrutura visual do texto multimodal.

A GDV está para o texto visual assim como a sintaxe está para o texto verbal, pois, na comunicação visual, em vez de estruturas oracionais, há semioses e modalidades diversas, como cores, formato, fonte, imagens, molduras, etc. Sobre esse aspecto, Jewitt e Oyama (2001 apud VIEIRA e FERRAZ, 2011, p. 13) asseveram que a linguagem visual faz parte da semiótica social, já que a semiótica social envolve "[...] a descrição dos recursos semióticos, o que pode ser dito e feito com imagens (e outros meios visuais [...]), além de como as coisas que as pessoas dizem e fazem com as imagens podem ser interpretadas".

Na GDV, conforme Kress e van Leeuwen (2006), as formas visuais são estudadas vinculadas aos seus significados, como forma de experiência e interação social, assim, “[...] as mensagens produzidas pelos indivíduos refletirão as diferenças, as incongruências e os embates que caracterizam a vida social" (KRESS e VAN LEEUWEN apud VIEIRA e FERRAZ, 2011, p. 15).

As categorias selecionadas foram retiradas da obra de Kress e van Leeuwen (2006), baseadas nas metafunções da semiótica da linguagem de Halliday (1978) e adequadas como metafunções para o plano visual.

\footnotetext{
${ }^{24}$ Tradução minha do texto original: "Like linguistic structures, visual structures point to particular interpretations of experience and forms of social interacion. To some degree these can also be expressed linguistically". (KRESS e VAN LEEUWEN, 2006, p. 2)
} 
Quadro 7 - Categorias da Gramática do Design Visual

\begin{tabular}{|c|l|}
\hline \multicolumn{1}{|c|}{ Metafunção } & Elementos \\
\hline Metafunção Ideacional & Estrutura narrativa \\
& Estrutura conceitual \\
\hline \multirow{3}{*}{ Metafunção Interpessoal } & Contato \\
& $\begin{array}{l}\text { Distância social } \\
\text { Atitude } \\
\\
\text { Poder }\end{array}$ \\
\hline Metafunção Textual & Valor da informação \\
& Saliência \\
& Enquadramento \\
\hline
\end{tabular}

Fonte: Kress e van Leeuwen (2006).

Conforme Kress e van Leeuwen (2006), a Metafunção Ideacional é formada por estruturas conceituais (representam os participantes) ou narrativas (há a presença de um vetor ou de um traço que indique direcionalidade). Quanto à Metafunção interpessoal, ela se relaciona com o leitor (viewer) e geralmente dá alguma informação a ele ou requer algo dele. A última, a Metafunção textual, refere-se ao conteúdo do texto. Abaixo apresentarei os conceitos dos elementos de cada categoria (metafunção).

\subsubsection{Estruturas Narrativas}

O que caracteriza uma estrutura narrativa visual é a presença de um vetor, de um traço que indique direcionalidade. De acordo com Kress e van Leeuwen (2006), o que na linguagem é realizado por 'verbos de ação', é visualmente realizado por vetores; eles são linhas que podem estar representadas de forma expressa ou tácita, inclusive podem causar efeito de movimento na imagem. Dentro das representações narrativas, estão: os participantes, os processos narrativos e os processos conceituais.

Participantes são pessoas, lugares, coisas - inclusive abstratas, que são representadas no discurso verbal ou não verbal. Há dois tipos de participantes:

a) Participantes interativos - são os objetos do discurso, representados por pessoas, lugares ou coisas.

b) Participantes representados - são os receptores do discurso, os leitores - ou viewers, em se tratando de texto visual. 
Nos processos narrativos, os participantes são conectados por um vetor ${ }^{25}$. "Os padrões narrativos servem para apresentar ações e eventos de desdobramento, processos de mudança, arranjos espaciais transitórios" (KRESS e VAN LEEUWEN, 2006, p. 59). Eles são divididos em:

a) Processo de ação - nele o ator é o participante do qual o vetor emana, ele é o participante mais saliente, por meio de posição no espaço, de contraste, de cores, etc. O processo de ação pode ser: i) Transacional: há pelo menos dois participantes - o ator (actor), que é o protagonista, o que pratica a ação; e o objeto (goal), para quem a ação se direciona. ii) Não-transacional: há apenas um participante - o ator.

b) Processo de reação - ocorre quando o vetor é formado por uma "direção de olhar" (eyeline). Aqui não há ator, mas reagente (reacter) e fenômenos (phenomena). $\mathrm{O}$ participante que aparece e direciona o olhar, o reagente, deve ser humano ou animal com olhos visíveis e expressão facial. Enquanto o fenômeno pode ser formado por outro participante - interativo ou representado, por exemplo, por uma estrutura transacional.

Nos processos conceituais, o foco está nos atributos e nas identidades dos participantes, identificados por características específicas. São eles:

a) Processo classificatório - apresenta hierarquia, implícita ou explicita, entre os participantes pelo tipo de reação que há entre eles, assim um participante pode ser subordinado ao outro.

b) Processo analítico - representa os participantes no texto em uma relação todo/ parte, dessa forma, os participantes podem ser representados inteiros (todo) ou apenas por uma parte - por exemplo, um pé simbolizando os passos. Essa representação dependerá do foco a ser apresentado no texto.

c) Processo simbólico - acrescenta informações adicionais ao texto e/ou efeitos que permitem simbolismo na representação.

\footnotetext{
${ }^{25}$ Tradução minha do texto original: "Narrative patterns serve to present unfolding actions and events,
} processes of change, transitory spatial arrangements" (KRESS e VAN LEEUWEN, 2006, p. 59). 


\subsubsection{A Composição do Significado no Espaço}

A composição do significado no espaço se refere à organização dos elementos no espaço do texto, que pode ser observada por meio de três aspectos que serão detalhados a seguir: valores informacionais, saliência e enquadramento (framing).

Valores informacionais são as zonas da imagem: os planos superior e inferior, as margens direita e esquerda e o centro/ as bordas da imagem. As zonas da imagem podem representar:

a) Dado e novo - o valor da informação da esquerda é a informação dada, conhecida; e o da direita é a informação nova. Com a disposição das margens direita e esquerda, o texto pode representar mais ou menos importância ou ênfase dependendo da colocação dos elementos, pode também pressupor que informação do texto é conhecida (dada) e qual é nova.

b) Ideal e real - o valor da informação do plano superior é o ideal; e do inferior é o real. Esses elementos também podem direcionar a parte considerada mais relevante no texto, fazendo uma comparação, por exemplo, do real e do ideal, valorizando geralmente a parte superior, que representa o ideal.

A saliência representa o destaque a alguma ou algumas partes do texto dependendo da forma constituída: é realizada por fatores como localização no primeiro (maior destaque, em primeiro lugar) ou segundo plano (destaque em segundo lugar), tamanho, perspectiva, contrastes de tonalidade ou cor, diferenças de brilho.

Os elementos são posicionados para atrair o viewer. Eles podem apresentar hierarquia de importância, sendo o mais importante o que demanda mais atenção. $\mathrm{O}$ dado ou o novo também podem ser mais salientes; o ideal ou o real; o centro ou a margem. Todas essas variações são formas de dar destaque ou ênfase propositalmente às partes do texto.

O enquadramento (framing) representa a direcionalidade para o foco do texto, a moldura do texto. Os elementos que compõem o enquadramento podem enquadrar fortemente ou fracamente as partes do texto, de acordo com as formas que ele se apresenta, sendo algumas a presença de linhas, de contorno, de sombra, de descontinuidades de cor e de espaços vazios entre os elementos. 


\subsubsection{A Composição Interacional}

É a relação estabelecida entre os participantes representados e o leitor, através de contato, distância social, atitude e poder. O contato marca maior (pessoal) ou menor (impessoal) interação entre o participante representado humano, ou personificado, e o leitor (viewer). Esse contato pode ser classificado como:

a) Oferta - o participante é objeto de contemplação, é um mostruário.

b) Demanda - o participante olha direto para o viewer, realiza contato visual.

A distância, ou afinidade social, indica proximidade ou distância social com o leitor. Pode ser realizada pelo tamanho da moldura ou pelos tipos de enquadramento; ou pela distância que é vista - de perto (íntimo - close shot), de média distância (social medium shot) ou de longe (impessoal - long shot).

De outro modo, um elemento que revela a perspectiva da imagem, o ângulo ou o ponto de vista a partir do qual os participantes representados são retratados é a atitude. Essa atitude pode ser revelada pelo posicionamento do participante, que pode representar maior ou menor envolvimento em relação ao leitor. As posições podem ser: de frente, de lado ou de costas. O maior envolvimento é representado pelo ângulo frontal, dessa forma, o maior distanciamento é representado pelo ângulo de costas.

O último elemento, o poder, é representado a partir de um eixo horizontal em que o leitor observa o texto por meio de três ângulos:

a) Alto - é a leitura do texto a partir de um nível superior, que indica maior poder do leitor.

b) Direto - evidencia posição de igualdade entre o participante do texto e o leitor.

c) Baixo - indica que o leitor vê o texto de baixo, ele fica em uma posição inferior comparada aos participantes do texto.

Após conceituar as categorias da GDV que foram selecionadas para a análise, sigo apresentamos as categorias dos Multiletramentos. 


\subsubsection{Categorias dos Multiletramentos}

Kress e van Leeuwen (2006) relatam que a comunicação visual está disseminada nos "impérios culturais/tecnológicos globais" por meio da tecnologia de imagem computacional. Essa linguagem exige leitores mais atentos, críticos e atualizados, o que nos remete a leitores "multiletrados", como é ilustrado abaixo a partir das considerações de Rojo e Moura (2012).

Figura 6 - Competências do leitor multiletrado
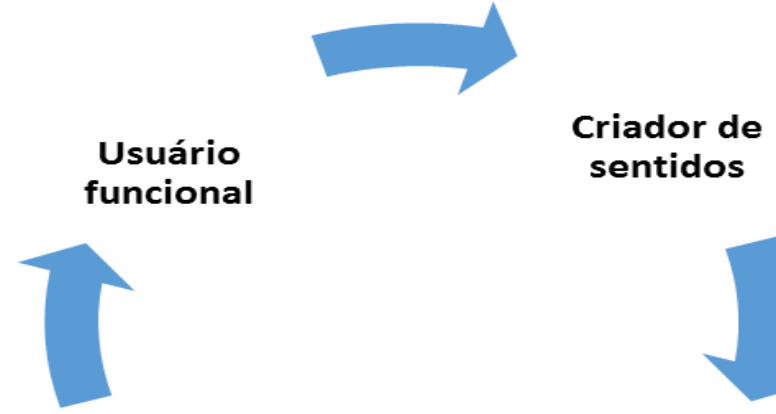

\section{Analista crítico}

Transformador

Fonte: a própria autora, com base em Rojo e Moura (2012, p. 29).

Por meio da figura acima, demonstro a ligação entre as competências de um leitor multiletrado: ele tem competência técnica e prática (usuário funcional); ele é capaz de criar sentidos a partir de diversas tecnologias (criador de sentidos); ele é capaz de transformar de novas formas o que foi aprendido (transformador); e de compreender que tudo o que é estudado é resultado de seleção prévia (analista crítico). Entendo que, quando essas competências estão presentes, elas dão mais sentido à compreensão textual e permitem que o leitor esteja mais apto a leitura multimodal.

Sobre os sentidos dos Multiletramentos, Rojo e Moura (2012) apresentam dois aspectos relevantes, que serão levados em consideração na análise do corpus:

a) A multiplicidade cultural das populações (diversidade cultural e linguística): é evidenciada pela presença de textos híbridos de diferentes letramentos, produzidos por escolha pessoal, política e socioeconômica. 
b) A multiplicidade semiótica de constituição dos textos (multiplicidade de canais de comunicação e mídia): é evidenciada pela existência de vários gêneros de discurso, por meio de mídias, tecnologias, línguas, variedades, linguagens, etc.

A partir dos modos de significado, propostos pelo GNL e apresentados por Cope e Kalantzis (2000), selecionei as categorias que serão utilizadas; elas serão explicadas a seguir.

Figura 7 - Tríade analítica dos Multiletramentos

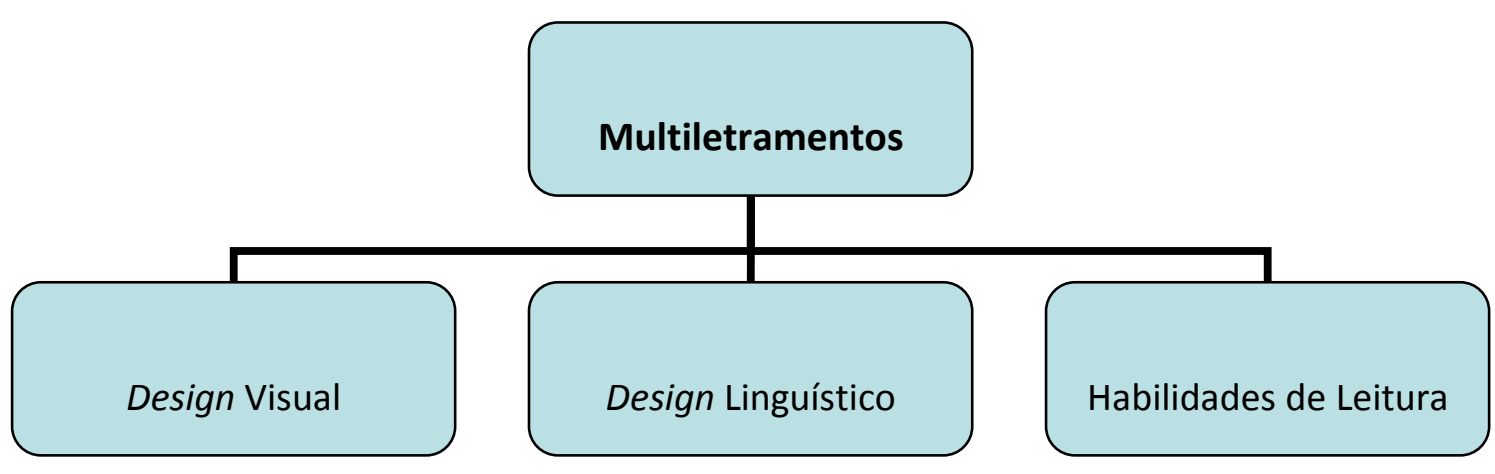

Fonte: a própria autora.

O Design Visual abrange a multiplicidade semiótica que constitui os textos, por meio de elementos de significado visual. As categorias da GDV, detalhadas no item 3.3.1, fazem parte da reflexão e explicação desse quesito.

Além da sintaxe e da semântica, o Design Linguístico trata da multiplicidade das produções textuais, por meio da diversidade cultural e linguística, com a presença de textos híbridos de diferentes letramentos, produzidos por escolha pessoal, política e socioeconômica. Ele envolve conhecimentos linguísticos, factuais (enciclopédicos), específicos (pessoais), de normas (institucionais, culturais, sociais) e lógicos (processos) (MARCUSCHI, 2008).

As competências a seguir foram desenvolvidas por Rojo e Moura (2012) em consonância com Cope e Kalantzis (2000) e serão norteadoras para investigar como os Multiletramentos são abordados por meio do design linguístico nas questões a serem analisadas. 
Quadro 8 - Competências de leitores multiletrados

\begin{tabular}{|c|l|}
\hline Característica & \multicolumn{1}{c|}{ Competência } \\
\hline Leitor usuário funcional & $\begin{array}{l}\text { Tem competência técnica e/ou conhecimento prático para } \\
\text { personalizar (ressignificar) experiências em diversos contextos. }\end{array}$ \\
\hline Leitor analista crítico & Entende que tudo que ele estuda ou lê é fruto de seleção prévia. \\
\hline $\begin{array}{c}\text { Leitor criador de } \\
\text { sentidos }\end{array}$ & Compreende textos híbridos e tecnologias operantes. \\
\hline Leitor transformador & $\begin{array}{l}\text { Usa o que aprendeu de novos modos, transforma teorias em } \\
\text { novas práticas }\end{array}$ \\
\hline
\end{tabular}

Fonte: a própria autora, com base em Cope e Kalantzis (2000) e Rojo e Moura (2012).

O último item da tríade, as habilidades de leitura, será voltado às características do leitor multiletrado e às leituras multimodais. Para isso, selecionei algumas competências e habilidades da matriz de referência Linguagens, Códigos e suas Tecnologias, criadas para nortear a elaboração das provas do Enem.

Competência de área 1 - Aplicar as tecnologias da comunicação e da informação na escola, no trabalho e em outros contextos relevantes para sua vida.

H1 - Identificar as diferentes linguagens e seus recursos expressivos como elementos de caracterização dos sistemas de comunicação.

H2 - Recorrer aos conhecimentos sobre as linguagens dos sistemas de comunicação e informação para resolver problemas sociais.

H3 - Relacionar informações geradas nos sistemas de comunicação e informação, considerando a função social desses sistemas.

H4 - Reconhecer posições críticas aos usos sociais que são feitos das linguagens e dos sistemas de comunicação e informação.

Competência de área 5 - Analisar, interpretar e aplicar recursos expressivos das linguagens, relacionando textos com seus contextos, mediante a natureza, função, organização, estrutura das manifestações, de acordo com as condições de produção e recepção.

H15 - Estabelecer relações entre o texto literário e o momento de sua produção, situando aspectos do contexto histórico, social e político.

H16 - Relacionar informações sobre concepções artísticas e procedimentos de construção do texto literário. 
H17 - Reconhecer a presença de valores sociais e humanos atualizáveis e permanentes no patrimônio literário nacional.

Competência de área 6 - Compreender e usar os sistemas simbólicos das diferentes linguagens como meios de organização cognitiva da realidade pela constituição de significados, expressão, comunicação e informação.

H18 - Identificar os elementos que concorrem para a progressão temática e para a organização e estruturação de textos de diferentes gêneros e tipos.

H19 - Analisar a função da linguagem predominante nos textos em situações específicas de interlocução.

H20 - Reconhecer a importância do patrimônio linguístico para a preservação da memória e da identidade nacional.

Competência de área 7 - Confrontar opiniões e pontos de vista sobre as diferentes linguagens e suas manifestações específicas.

H21 - Reconhecer em textos de diferentes gêneros, recursos verbais e não-verbais utilizados com a finalidade de criar e mudar comportamentos e hábitos.

H22 - Relacionar, em diferentes textos, opiniões, temas, assuntos e recursos linguísticos.

H23 - Inferir em um texto quais são os objetivos de seu produtor e quem é seu público alvo, pela análise dos procedimentos argumentativos utilizados.

H24 - Reconhecer no texto estratégias argumentativas empregadas para o convencimento do público, tais como a intimidação, sedução, comoção, chantagem, entre outras.

Competência de área 8 - Compreender e usar a língua portuguesa como língua materna, geradora de significação e integradora da organização do mundo e da própria identidade.

H25 - Identificar, em textos de diferentes gêneros, as marcas linguísticas que singularizam as variedades linguísticas sociais, regionais e de registro.

H26 - Relacionar as variedades linguísticas a situações específicas de uso social.

H27 - Reconhecer os usos da norma padrão da língua portuguesa nas diferentes situações de comunicação. 
Competência de área 9 - Entender os princípios, a natureza, a função e o impacto das tecnologias da comunicação e da informação na sua vida pessoal e social, no desenvolvimento do conhecimento, associando-o aos conhecimentos científicos, às linguagens que lhes dão suporte, às demais tecnologias, aos processos de produção e aos problemas que se propõem solucionar.

H28 - Reconhecer a função e o impacto social das diferentes tecnologias da comunicação e informação.

H29 - Identificar pela análise de suas linguagens, as tecnologias da comunicação e informação.

H30 - Relacionar as tecnologias de comunicação e informação ao desenvolvimento das sociedades e ao conhecimento que elas produzem.

Selecionei aqui apenas as competências e habilidades que dizem respeito às questões que demandam conhecimentos da Língua Portuguesa e áreas afins, visto que as análises serão feitas contemplando essas áreas. As competências representam o que se espera de conhecimento do candidato que realiza o exame, enquanto as habilidades são avaliadas na elaboração das questões para que se chegue às competências esperadas.

Utilizarei as habilidades acima descritas para analisar como elas são avaliadas e representadas nas questões e como elas se relacionam com as competências de um leitor multiletrado. Finalizada a parte metodológica, seguirei, então, para o capítulo analítico. 


\section{ANÁliSE de DADOS: A COMPOSIÇÃO MULTISSEMIÓTICA E SUAS RELAÇÕES COM OS MULTILETRAMENTOS}

Antes de prosseguir, convém aqui relembrar o objetivo geral desta dissertação: analisar questões das provas de LP do Enem à luz das teorias de Multiletramentos e Multimodalidade para verificar a ocorrência de textos multimodais e as habilidades de leitura que são requeridas para a compreensão desses textos.

No capítulo anterior, descrevi as categorias da GDV e dos Multiletramentos que serão abordadas na análise. Dentre elas, utilizarei as que forem adequadas ao corpus selecionado, o qual será melhor elucidado no próximo tópico.

\subsection{A Seleção do Corpus}

A escolha das questões foi realizada após um levantamento de dados dos textos motivadores dos cadernos de provas de Linguagens, Códigos e suas Tecnologias (LCT) das primeiras aplicações do Enem dos anos de 2009 a 2016 - 45 questões do ano de 2009, ano em que não houve questões de Língua Estrangeira Moderna (LEM); e 50 questões dos anos de 2010 a 2016, entre elas há dez de LEM (cinco de Inglês e cinco de Espanhol), pois os estudantes podem optar por uma no momento da inscrição.

Entre outros quesitos observados, em cada questão, verifiquei se há: texto motivador, texto multimodal e imagem. É importante salientar que, para o levantamento de dados e para a seleção dos textos, não julguei como texto multimodal os textos verbais com destaque apenas para o título em negrito, por exemplo, uma vez que são o padrão mais encontrado nos textos das provas observadas. Dessa forma, considero como texto multimodal, neste trabalho, textos que possuam mais de uma semiose evidente, como texto verbal, figura, desenho, pintura, cartaz, gráfico, infográfico, tabela, quadro, recorte de revista ou jornal, recorte de página da web, etc.

Abaixo apresento os resultados do levantamento de dados das provas organizados por ano: 
Quadro 9 - Caderno de Linguagens, Códigos e suas Tecnologias

\begin{tabular}{|c|c|c|c|}
\hline Ano & $\begin{array}{c}\text { Texto } \\
\text { Motivador }\end{array}$ & $\begin{array}{c}\text { Texto } \\
\text { multimodal }\end{array}$ & Imagem \\
\hline $\begin{array}{c}2009 \\
(45 \text { questões })\end{array}$ & 43 & 13 & 13 \\
\hline $\begin{array}{c}2010 \\
\text { (50 questões) }\end{array}$ & 50 & 13 & 11 \\
\hline $\begin{array}{c}2011 \\
\text { (50 questões) }\end{array}$ & 50 & 15 & 14 \\
\hline $\begin{array}{c}2012 \\
\text { (50 questões) }\end{array}$ & 50 & 17 & 8 \\
\hline $\begin{array}{c}2013 \\
\text { (50 questões) }\end{array}$ & 50 & 9 & 8 \\
\hline $\begin{array}{c}2014 \\
\text { (50 questões) }\end{array}$ & 50 & 9 & 8 \\
\hline $\begin{array}{c}2015 \\
\text { (50 questões })\end{array}$ & 50 & 8 & 16 \\
\hline $\begin{array}{c}2016 \\
\text { (50 questões })\end{array}$ & 50 & & 8 \\
\hline
\end{tabular}

Fonte: a própria autora.

O quadro acima revela que, nas provas de 2009 a 2016, há mais da metade das questões apenas verbais. Esses dados demonstram que, a partir de 2014, as questões com textos motivadores multimodais diminuíram de forma considerada, o que, pela atualização e inserção de mais textos diversificados no meio social, a meu ver, deveria ser o contrário. A prova deveria possibilitar o aumento dos números de questões com esses tipos de texto no decorrer dos anos, e não a diminuição.

Verifico que, das questões com textos motivadores multimodais (dentro dos padrões por mim estabelecidos para o corpus deste trabalho), no geral, mais de oitenta por cento delas contêm imagem; isso pode ser justificado pela atenção que elas demandam, pela ênfase que elas dão à parte textual verbal, seja exemplificando, seja complementando, seja ilustrando, etc.

Após a observação de todos os textos do caderno de LCT, usei como critérios de seleção apenas os textos multimodais com imagens e, a partir deles, escolhi uma questão de cada edição entre os referidos anos, totalizando, assim, oito questões para análise, que contemplem gêneros variados, o que possibilita a identificação de categorias diversas. 


\subsection{Alguns Pontos Norteadores para a Análise}

Antes de iniciar as análises, proponho algumas perguntas orientadoras, estabelecidas a partir dos objetivos desta pesquisa e as quais pretendo responder durante e após o estudo analítico:

- Que tipos de textos multimodais estão presentes nas questões?

- Como os textos multimodais são utilizados para dar sentido às questões?

- Como elementos verbais e não verbais se relacionam na construção de sentido?

- Que competências da matriz de referência do Enem, avaliadas nas questões analisadas, se relacionam com as competências de um leitor multiletrado?

- Que competências dos multiletramentos são abordadas?

- Que habilidades de leitura são requeridas para a compreensão textual?

- Que relações entre Multimodalidade e Multiletramentos são observadas nas questões analisadas?

Concluída a parte introdutória com a explanação da seleção do corpus e com a inserção de perguntas norteadoras da reflexão durante a e depois da análise, passo para a apreciação e a análise das oito questões selecionadas.

\subsection{Análise de Questões Multimodais de Provas do Enem}

Além das questões norteadoras apresentadas do item anterior, utilizarei, para as análises, algumas categorias de Multiletramentos e de Multimodalidade, apontadas resumidamente abaixo, visto que foram detalhadas no item metodológico. 
Quadro 10 - Categorias de análise dos Multiletramentos

\begin{tabular}{|c|c|}
\hline Categorias & Elementos \\
\hline \multirow{2}{*}{ Significado Visual (GDV) } & Composição Representacional \\
\cline { 2 - 2 } & Composição do Significado \\
\cline { 2 - 2 } Significado Linguístico & Composição Interacional \\
\cline { 2 - 2 } (competências do leitor multiletrado) & Leitor usuário funcional \\
\cline { 2 - 2 } & Leitor criador de sentidos \\
\cline { 2 - 2 } & Leitor analista crítico \\
\hline \multirow{3}{*}{ Habilidades de Leitura } & Leitor transformador \\
& Matriz de referência de Linguagens, \\
& Códigos e suas Tecnologias \\
\hline
\end{tabular}

Fonte: a própria autora.

As categorias dos Multiletramentos foram pensadas e reunidas a partir das obras de Cope e Kalantzis (2000), de Rojo e Moura (2004), da GDV de Kress e van Leeuwen (2006) e da matriz de referência do Enem, da qual utilizo apenas as competências que condizem com as questões que abordam Língua Portuguesa e áreas afins. O segundo quadro de categorias é o da GDV, mostrado abaixo:

Quadro 11 - Categorias de análise da Gramática do Design Visual

\begin{tabular}{|c|c|c|}
\hline Categorias & Elen & \\
\hline \multirow{7}{*}{ Composição Representacional } & \multirow[b]{2}{*}{ Participantes } & Interativos \\
\hline & & Representados \\
\hline & \multirow[t]{2}{*}{ Processos Narrativos } & De ação \\
\hline & & De reação \\
\hline & \multirow{3}{*}{$\begin{array}{l}\text { Processos } \\
\text { Conceituais }\end{array}$} & Classificatório \\
\hline & & Analítico \\
\hline & & Simbólico \\
\hline \multirow{4}{*}{ Composição do Significado } & \multirow{2}{*}{$\begin{array}{c}\text { Valores } \\
\text { Informacionais }\end{array}$} & Dado e novo \\
\hline & & Ideal e real \\
\hline & \multicolumn{2}{|c|}{ Enquadramento } \\
\hline & \multicolumn{2}{|c|}{ Saliência } \\
\hline \multirow{6}{*}{ Composição Interacional } & \multicolumn{2}{|c|}{ Contato } \\
\hline & \multicolumn{2}{|c|}{ Distância ou afinidade social } \\
\hline & \multicolumn{2}{|c|}{ Atitude } \\
\hline & \multirow{3}{*}{ Poder } & Alto \\
\hline & & Direto \\
\hline & & Baixo \\
\hline
\end{tabular}

Fonte: a própria autora, com base em Kress e Leuween (2006). 
As categorias da GDV foram retiradas da obra de Kress e van Leeuwen (2006) e serão adotadas aqui pela utilização de textos multimodais como corpus deste trabalho, já que a GDV estuda a sintaxe visual desses tipos de texto. Nesta pesquisa, destaco diversas categorias de análise, tanto de Multiletramentos como de Multimodalidade, mesmo sabendo que possivelmente não utilizarei todas, pois as questões selecionadas é que irão requisitá-las, dependendo de suas características. Assim sendo, para seguir com a parte analítica, apresento abaixo as questões selecionadas e suas respectivas análises:

Figura 8 - Texto 1 - Questão 105/ 2009
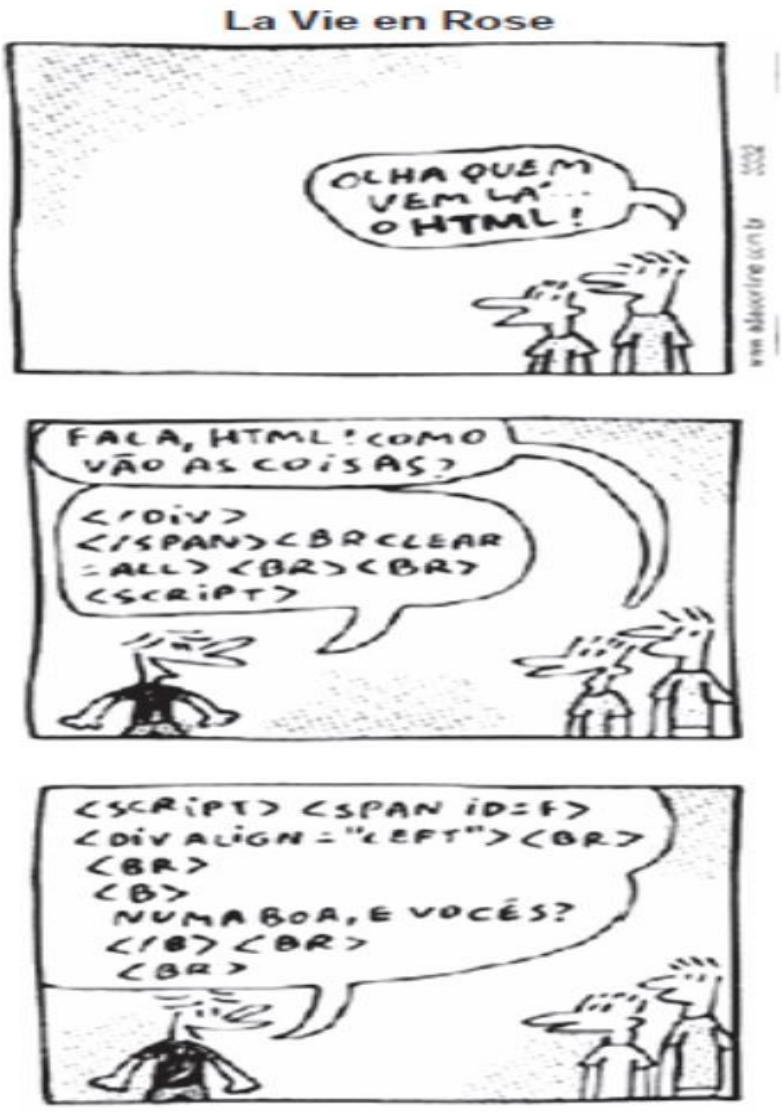

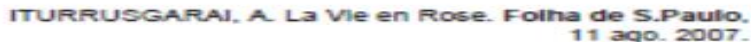




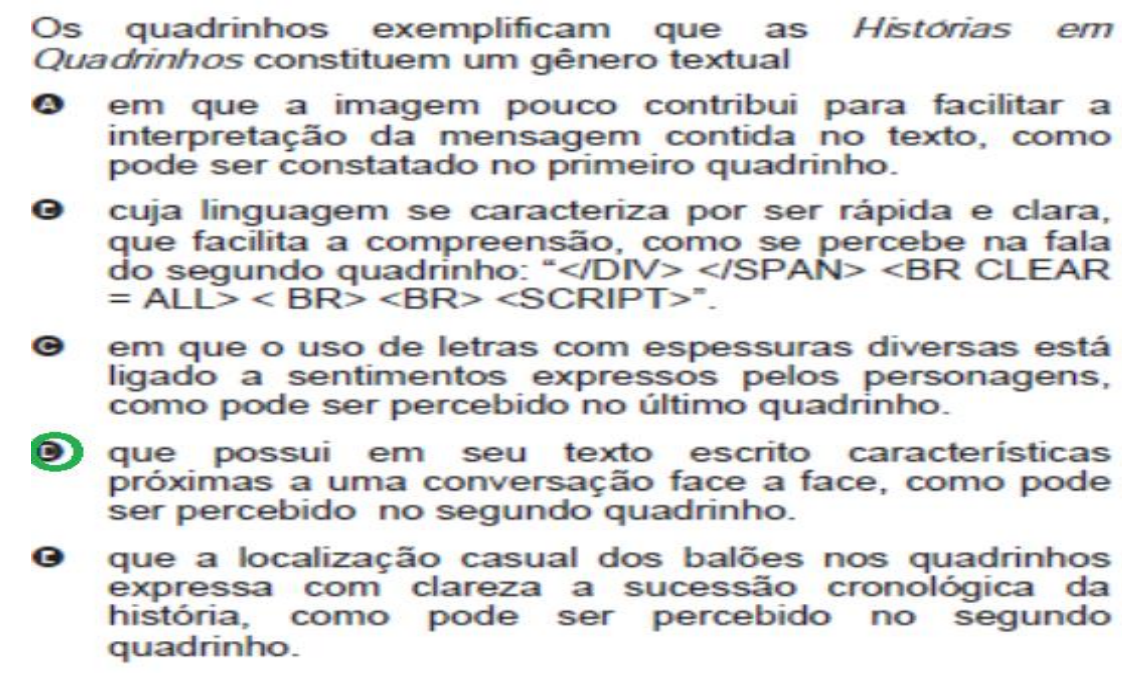

O texto 1 é uma história em quadrinhos de um autor que as publica no jornal Folha de São Paulo, e pertence a uma coleção cujo nome é "La Vie em Rose" (A vida cor de rosa), por isso o título da história recebe esse nome. Esse texto apresenta uma conversa entre amigos, entretanto não é uma conversa normal, trata-se de uma conversa que simula um discurso produzido em meios digitais, pela utilização de códigos ligados à informática.

No primeiro quadrinho, há um balão de conversa que se refere a uma personagem que ainda não está em cena, mas que consigo inferir que é uma pessoa, mesmo com o nome HTML (HyperText Markup Language ou Linguagem de Marcação de Hipertexto). A sigla HTML representa um processo conceitual, pois simboliza a tecnologia que interage com as pessoas ou que proporciona interação entre as pessoas. Contudo, no caso do texto 1, o HTML foi personificado como uma pessoa que interage (conversa) face a face com seus

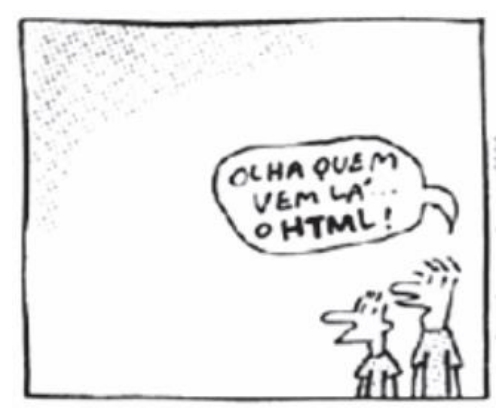
amigos.

Os balões em que há fala da personagem HTML recorrem à tecnologia da informação para a construção de sentidos, o que me permite afirmar que a linguagem

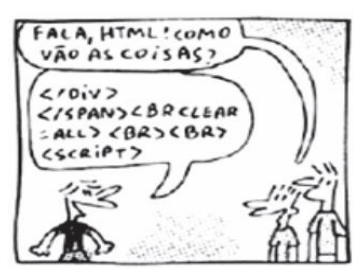
utilizada por "HTML" simula uma conversa online (pela linguagem $\mathrm{e}$ pelos hipertextos tecnológicos, como

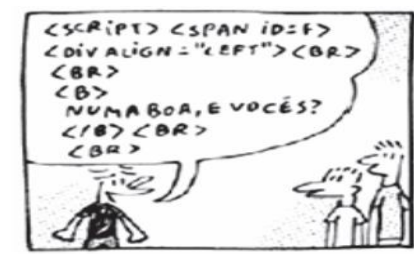


$<$ SCRIPT $>$ e </SPAN $>$, utilizados) e, ao mesmo tempo, face a face. Essa conversa mostra-se mais descontraída pela informalidade trazida por expressões como "vem lá", "Como vão as coisas?" e "Numa boa".

No texto 1, observo predominantemente algumas competências de leitor multiletrado, pois o texto requer habilidade de um leitor usuário funcional, porque há necessidade de conhecimento técnico de termos como "HTML" - não necessariamente saber seus significados, mas pelo menos compreender que essa sigla se refere à tecnologia da informação; habilidade de um leitor criador de sentidos, pois há necessidade de compreensão de textos diversificados, como a história em quadrinhos, e com tecnologias operantes (o nome "HTML" representa tecnologia); e de leitor transformador, pelo novo modo de demonstrar o tema tecnologia (em uma conversa simbólica e face a face do próprio HTML com seus amigos "reais" e não virtuais, apesar da linguagem virtual utilizada).

A partir das competências do Enem e das categorias dos multiletramentos, constato que a habilidade da matriz de referência predominante na questão 105 de 2009 é a H19: analisar a função da linguagem predominante nos textos em situações específicas de interlocução, visto que o texto apresenta conversa com linguagem informal e descontraída, por exemplo, "vem lá", "Como vão as coisas?" e "Numa boa". Mesmo que a habilidade escolhida se refira também à função da linguagem predominante, essa habilidade foi selecionada por por se tratar de uma situação específica de interlocução.

A meu ver, a linguagem informal utilizada para a conversa face a face no texto 1 representa intimidade entre os interlocutores; essa linguagem também representa a interação informal online. O texto, além disso, traz diversas marcas de interação digital, desde o nome da personagem, "HTML", à sua linguagem expressa por códigos dos meios digitais.

A função da linguagem predominante é avaliada na questão por meio do comando, que requer também que o estudante analise as características textuais "que constituem um gênero textual'. As alternativas buscam avaliar a função da linguagem predominante no texto. 
A alternativa A trata da linguagem visual (a imagem do primeiro quadrinho), exigindo a atenção do leitor para verificar se a imagem é fundamental para a interpretação da mensagem do texto. Quanto à $\mathbf{B}$, ainda trata da questão linguagem e requer que o leitor avalie se a linguagem com código de informática é clara e rápida.

Os quadrinhos exemplificam que as Historias em Quadrinhos constituem um gênero textual

- em que a imagem pouco contribui para facilitar a interpretação da mensagem contida no texto, como pode ser constatado no primeiro quadrinho.

- cuja linguagem se caracteriza por ser rápida e clara, que facilita a compreensão, como se percebe na fala do segundo quadrinho: $“</$ DIV $><$ ISPAN $><$ BR CLEAR $=A L L><B R>\langle B R>\langle$ SCRIPT $\rangle=$

๑ em que o uso de letras com espessuras diversas está ligado a sentimentos expressos pelos personagens, como pode ser percebido no último quadrinho. (D) que possui em seu texto escrito características ser percebido no segundo quadrinho.

- que a localização casual dos balões nos quadrinhos expressa com clareza a sucessão cronológica da história, como pode ser percebido no segundo quadrinho.
Enquanto a alternativa

C chama a atenção para as espessuras das letras no último quadrinho e para o significado do sentimento expresso (ou não) por elas, isso não pode ser avaliado na história em quadrinhos por se

tratar de uma conversa rotineira; quanto às espessuras das letras, elas apresentam-se de forma irregular, mas isso configura apenas um tipo de fonte.

Sobre a alternativa $\mathbf{D}$, que é a resposta correta, ela representa a função da linguagem predominante em uma interlocução: "características de uma conversação face a face", reproduzida pela interação de personagens no segundo quadrinho, em que há um diálogo entre duas delas, mesmo que o HTML reproduza uma fala por meio de códigos. A última alternativa, $\mathbf{E}$, requer do leitor um conhecimento de

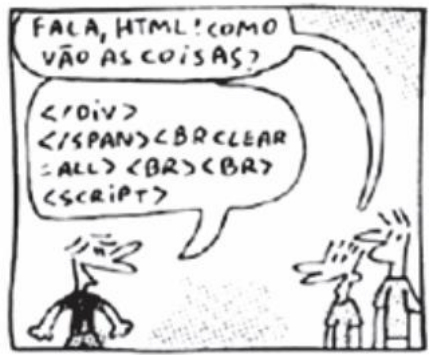
produção de histórias em quadrinho, pois discorre sobre a sucessão cronológica da história e a organização os balões de texto.

Observo que o texto 1 é repleto de recursos linguísticos para compor uma fala informal que faz referência à linguagem própria de uma conversa. Esses elementos requisitam leitores multiletrados, aptos a observar diversos itens que fazem parte da prática discursiva de uma conversa informal e que representam uma multiplicidade cultural: nas falas da personagem HTML, por exemplo, há traços de sua identidade, uma série de códigos tecnológicos utilizados na internet, que fortalecem suas origens: o meio digital online; a interlocução entre as personagens da história em quadrinhos é uma 
situação social que, pelos traços da conversa do "HTML", representa sua vida pessoal por meio da linguagem utilizada (códigos do meio digital).

Figura 9 - Texto 2 - Questão 132/ 2010

\section{CADA UM NA SUA}

O que a sexo dos matriculados nas universidades brasileiras diz sobre a mente dos machos e das temeas.

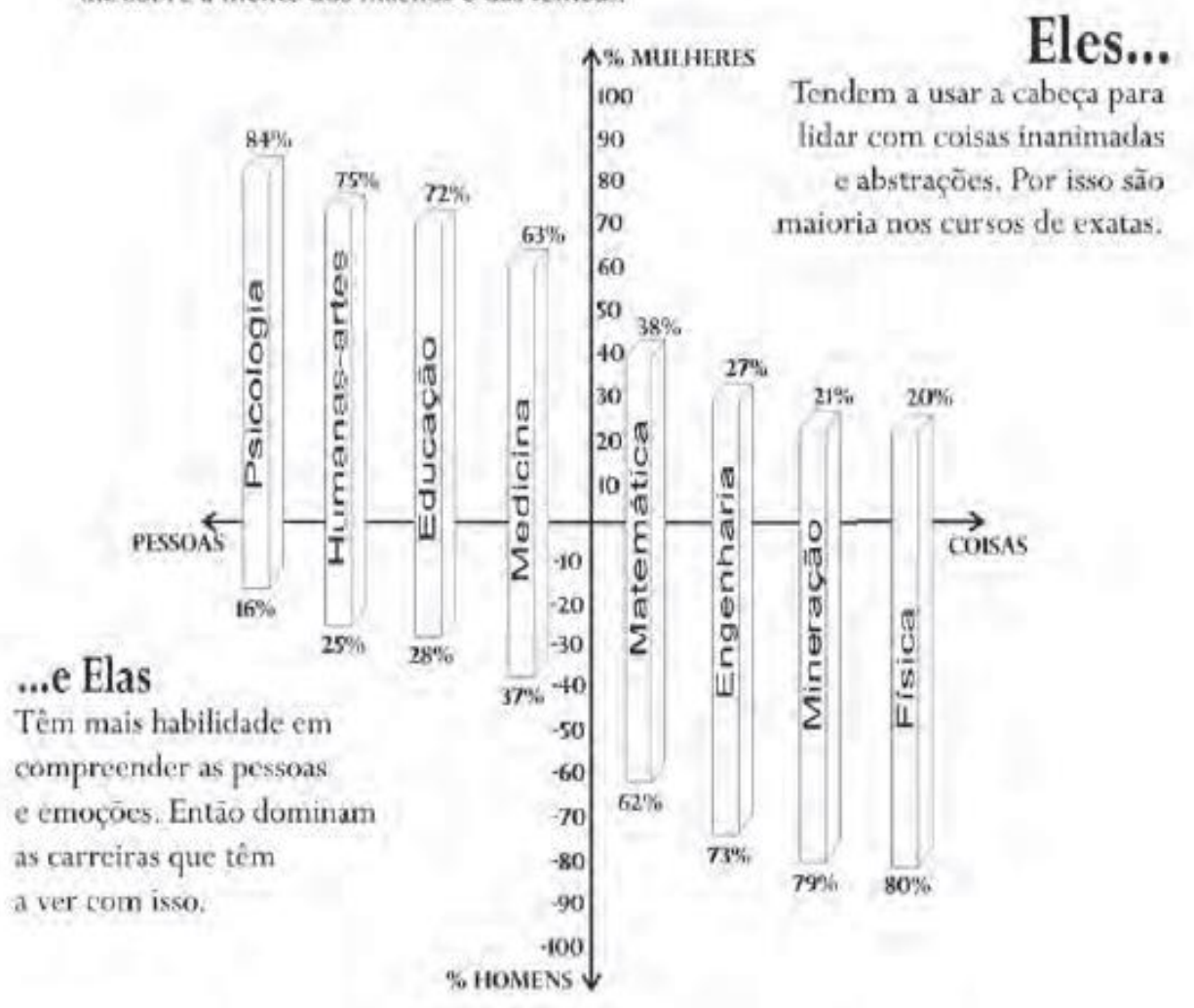

Superinteressante. Ed. 256 , set. 2008.

Segundo pesquisas recentes, é irrelevante a diferença entre sexos para se avaliar a inteligência. Com relação às tendências para áreas do conhecimento, por sexo, levando em conta a matrícula em cursos universitários brasileiros, as informações do gráfico asseguram que

- os homens estão matriculados em menor proporção em cursos de Matemática que em Medicina por lidarem melhor com pessoas.

(3) as mulheres estão matriculadas em maior percentual em cursos que exigem capacidade de compreensão dos seres humanos.

( ) as mulheres estão matriculadas em percentual maior em Física que em Mineração por tenderem a trabalhar melhor com abstrações.

- ( ) as homens e as mulheres estão matriculados na mesma proporção em cursos que exigem habilidades semelhantes na mesma área.

$\Theta$ as mulheres estão matriculadas em menor número em Psicologia por sua habilidade de lidarem melhor com coisas que com sujeitos.

LC - $2^{\circ}$ dia | Cademo 7 - AZUL - Página 18

O texto 2 apresenta um gráfico com informações sobre a porcentagem de matrículas nas universidades brasileiras por área de conhecimento conforme o sexo do 
candidato e o que isso tem de ligação com a mente feminina e masculina. Ele mostra a diferença de percentuais na escolha de cursos relacionados a pessoas ou a coisas entre os sexos feminino e masculino, percentuais apresentados por meio de gráfico e de textos explicativos.

A composição textual é bem complexa, pois há um título em destaque, em caixa alta e em negrito (CADA UM NA SUA), seguido de um texto que introduz o assunto ("O que o sexo dos matriculados nas universidades brasileiras diz sobre a mente dos machos e das fêmeas.”), um gráfico com múltiplas informações, textos explicativos (um do lado direito e um do lado esquerdo do gráfico) e, ainda, o comando da questão ("é irrelevante a diferença entre sexos para se avaliar a inteligência") que, no meu ponto de vista, pode confudir o candidato que está lendo e respondendo a esssa questão da prova do Enem, fato que explicarei posteriormente.

Partindo do texto verbal que está fora do gráfico, verifico destaque, em primeiro plano (por ser maior e mais visual), tornando-o mais CADA UM NA SUA

relevante, para o título em caixa O que a sexo dos matriculados nas universidades braxileiras alta ("CADA UM NA SUA") diz sobre a mente dos machos e das fémeas.

que apresenta o texto. Em

seguida, o texto abaixo do título, em menor destaque ("O que o sexo dos matriculados nas universidades brasileiras diz sobre a mente dos machos e das fêmeas.") explica o assunto que será abordado na questão. Nele salientamos as palavras "machos" e "fêmeas", vocábulos que geralmente se reportam a animais e que aqui foram utilizados para se referir a seres humanos, por isso entendo esse uso aponta para a reprodução uma perspectiva biológica e determinista, pois considera "regras" quando generaliza os sexos feminino e masculino, deixando pouco espaço para exceções quanto à tendência dos tipos de cursos escolhidos por eles. 
Enquanto o gráfico, que compõe sentidos em variadas direções, nos traz: do lado esquerdo, informações sobre os cursos mais procurados pelas mulheres (cursos relacionados a pessoas com as porcentagens na parte superior) e, ao mesmo tempo,

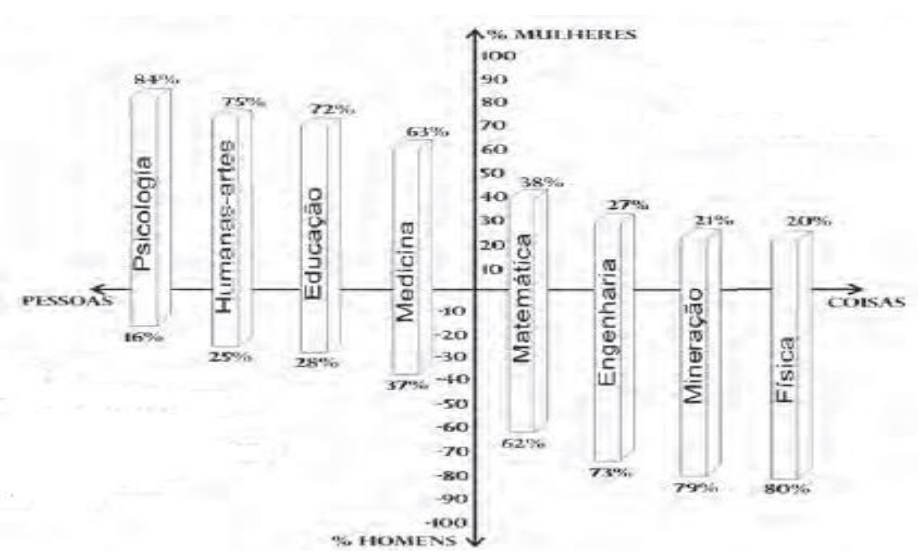
menos realizados pelos homens (com as porcentagens na parte inferior); do lado esquerdo, informações sobre os cursos mais procurados pelos homens (cursos relacionados a coisas com as porcentagens na parte inferior) e, ao mesmo tempo, menos realizados pelas mulheres (com as porcentagens na parte superior).

Nos lados esquerdo e direito do gráfico, observamos textos que explicam as áreas de conhecimento com que cada sexo mais se identifica: "Eles... Tendem a usar a cabeça para lidar com coisas inanimadas e abstrações. Por isso são maioria nos cursos de exatas.”; “... e Elas Têm mais habilidade em compreender as pessoas e emoções. Então dominam as carreiras que têm a ver com isso.”.

A composição do significado no espaço é feita por meio de saliência: o gráfico chama mais atenção por estar ao centro, ficando então em primeiro plano, por isso ele assume papel de destaque no texto; em segundo plano, estão o título em caixa alta e o "Eles...", por estar com fonte maior e em negrito, o que o iguala ao título quanto ao valor, que está em caixa alta,

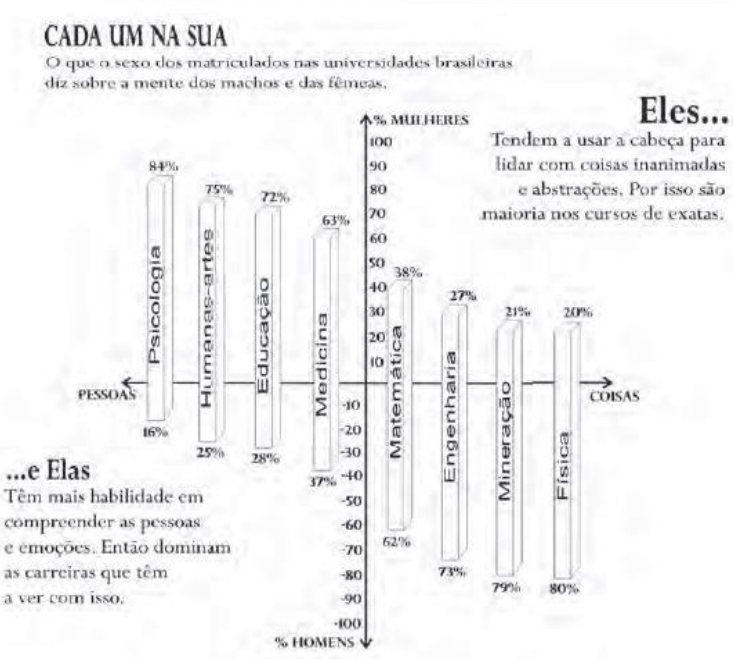
mas com fonte um pouco menor.

Os valores informacionais aqui não podem ser medidos pelos elementos dado e novo ou ideal e real, visto que observo, por meio do processo conceitual classificatório, referência aos homens e às mulheres nos planos superior e inferior - 
tanto no gráfico como nos textos explicativos: das mulheres no plano superior (no gráfico) e no plano inferior (no texto explicatico); e dos homens no plano superior (no texto explicatico) e no plano inferior (no gráfico). Isso permite considerar igualdade quanto às areas de habilidade que cada sexo tem, pois, nas que um se destaca mais, o outro não tem tanta habilidade e assim o contrário também se aplica.

Entretanto, não afirmo essa possível igualdade pelo fato de haver uma troca de lados para o início do período, pois, como é usual que se comece um texto da esquerda para a direita, aqui essa ordem é inversa, o que possibilita mais destaque e, consequentemente, mais poder a palavra "Eles...”, enquanto o “...e Elas", que deveria estar do lado direito pela ordem lógica de ser a sequência do mesmo texto, ao contrário, encontra-se do lado esquerdo e ainda com fonte menor, o que também configura menos poder em relação a "Eles...”.

Ainda em relação aos textos explicativos, destaco que, na primeira parte "Eles... Tendem a usar a cabeça para lidar com coisas inanimadas e abstrações. Por isso são maioria nos cursos de exatas.”, há afirmação verídica sobre eles, sem haver qualquer referência às mulheres. Enquanto, na segunda parte “... e Elas Têm mais habilidade em compreender as pessoas e emoções. Então dominam as carreiras que têm a ver com isso.”, quando há uso dos termos detacados, não há exclusão de que os homens também tenham habilidade para compreender as pessoas e as emoções, haja vista que elas têm apenas mais habilidade.

Quanto ao comando da questão, considero que ele pode confundir os estudantes que realizam a prova pelo trecho "Segundo pesquisas recentes, é irrelevante a diferença entre sexos para se avaliar a inteligência.", pois há informações, no texto motivador, que comprovam a diferença entre os sexos na escolha e no domínio de cursos ligados a áreas diferentes, o que configura mais facilidade e mais identificação com esses cursos e, consequentemente, mais "inteligência" nesses quesitos; isso pode ser exemplificado pelos trechos "Eles... Tendem a usar a cabeça para" e "Elas Têm mais habilidade".

No texto 2, ressalto algumas categorias dos multiletramentos que se relacionam às competências de matriz de LCT do Enem e que estão mais predominantes. Esse texto requer habilidade de um: leitor usuário funcional, pois há demanda de conhecimentos técnicos para a compreensão do texto (matemática - porcentagem e gráfico); leitor criador de sentidos, pela demanda de entendimento de textos multimodais (com 
gráfico complexo) para a compreensão da comparação entre os dois sexos por meio de um único gráfico; leitor transformador, pois requer a leitura e compreensão de novos modos (através de gráfico multi-informativo e de informações verbais com fontes e tamanhos diversos) de demonstrar as maiores e as menores habilidades de ambos os sexos.

Sobre as habilidades avaliadas nas questões do Enem, verifico a predominância da H22 - relacionar, em difererentes textos, opiniões, temas (a mente dos machos e das fêmeas), assuntos (a diferença entre os sexos na escolha de cursos) e recursos linguísticos (gráfico multiinformativo e textos verbais).

Segundo pesquisas recentes, é irrelevante a diferença entre sexos para se avaliar a inteligência. Com relação às tendências para áreas do conhecimento, por sexo, levando em conta a matrícula em cursos universitários brasileiros, as informaçōes do gráfico asseguram que

A os homens estão matriculados em menor proporção em cursos de Matemática que em Medicina por lidarem melhor com pessoas.

(B) as mulheres estão matriculadas em maior percentual em cursos que exigem capacidade de compreensão dos seres humanos.

๑ as mulheres estão matriculadas em percentual maior em Física que em Mineração por tenderem a trabalhar melhor com abstrações.

(D) as homens e as mulheres estão matriculados na mesma proporção em cursos que exigem habilidades semelhantes na mesma área.

๑ as mulheres estão matriculadas em menor número em Psicologia por sua habilidade de lidarem melhor com coisas que com sujeitos.

LC - $2^{\circ}$ dia | Cademo 7 - AZUL - Página 18

O comando dessa questão direciona a leitura para a parte do gráfico do texto ("levando em conta a matrícula em cursos universitários brasileiros, as informações do gráfico asseguram que"), pois, além das informações no comando da questão, em todas as alternativas, há informações sobre percentual, ou sobre proporção, ou sobre números quanto à escolha de cursos entre mulheres e homens.

Essa questão requer um leitor multiletrado e conhecedor de diversas modalidades textuais para que ele compreenda os textos multimodais apresentados nas questões do Enem, estabeleça relaçõe entre os textos e as informações por eles apresentadas, reconhecendo as estratégias argumentativas e os objetivos do(s) texto(s). As instruções da questão demandam que o candidato compreenda a leitura principalmente do gráfico, para que ele responda corretamente.

O que percebo, no texto 2, é a premissa de leituras multimodais e multiletradas assim como de pré-requisitos que envolvem a matemática, para o entendimento da questão, porque ela apresenta um gráfico complexo com muitas informações e que mostram, ao mesmo tempo, maiores e menores habilidades dos dois sexos. Por isso, evidencio a importância de os estudantes manterem contato com textos diversos e por 
meio de várias modalidades e mídias para que estejam familiarizados com esse tipo de leitura.

Figura 10 - Texto 3 - Questão 97/ 2011

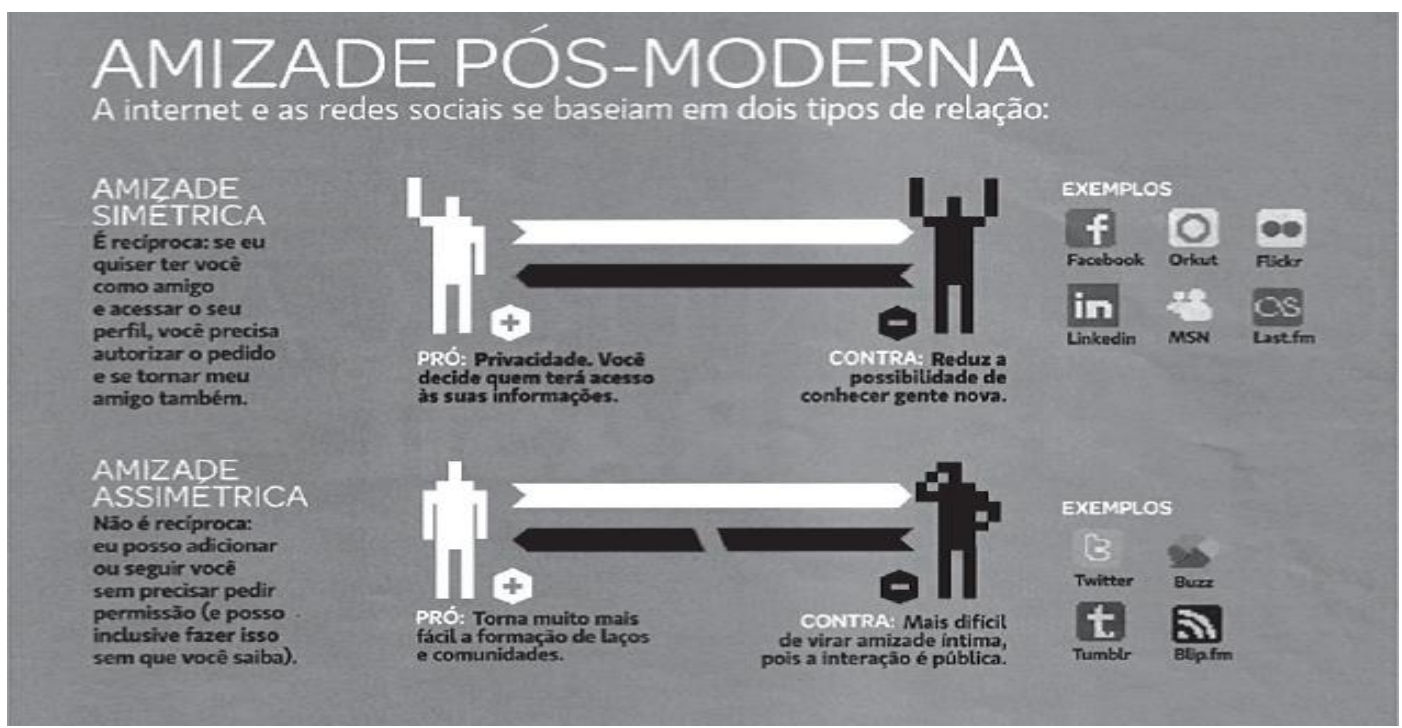

CosTA, C. Superinteressante. Fev. 2011 (adaptado).

Os amigos são um dos principais indicadores de bem-estar na vida social das pessoas. Da mesma forma que em outras áreas, a internet também inovou as maneiras de vivenciar a amizade. Da leitura do infográfico, depreendem-se dois tipos de amizade virtual, a simétrica e a assimétrica, ambas com seus prós e contras. Enquanto a primeira se baseia na relação de reciprocidade, a segunda

(A) reduz o número de amigos virtuais, ao limitar 0 acesso à rede.

8 parte do anonimato obrigatório para se difundir.

Q. reforça a configuração de laços mais profundos de amizade.

(D) facilita a interação entre pessoas em virtude de interesses comuns.

$\exists$ tem a responsabilidade de promover a proximidade fisica.

O texto 3 é um infográfico que apresenta uma comparação entre as relações de amizades pós-modernas nas redes sociais, destacando suas vantagens e desvantagens e classificando-as como simétricas ou assimétricas, além disso traz exemplos de redes sociais em que cada tipo de amizade está presente.

O infográfico é composto por meio do uso de diversas semioses: texto em caixa alta, texto menor, diferentes tamanhos de fontes, cores (preto e branco) nos textos e nas imagens, e exemplos de redes sociais com suas logomarcas. Essas variadas informações ocupam diversos espaços dentro do texto motivador e tornam a leitura mais complexa por permitir que seja feita de várias formas ou ordens, por exemplo, da parte superior para a inferior, da esquerda para a direita, ou por linhas, separando as informações da amizade simétrica e da assimétrica. 
Optei, como leitora, por fazer a leitura analítica por linhas de informações, assim dividi o texto em três partes formadoras de sentidos que se unem para a composição do significado textual: o título e sua explicação, a linha da amizade simétrica e a linha da amizade assimétrica.

O título do texto motivador "AMIZADE PÓS-MODERNA" se refere às amizades por meio da internet e/ou das redes sociais, para

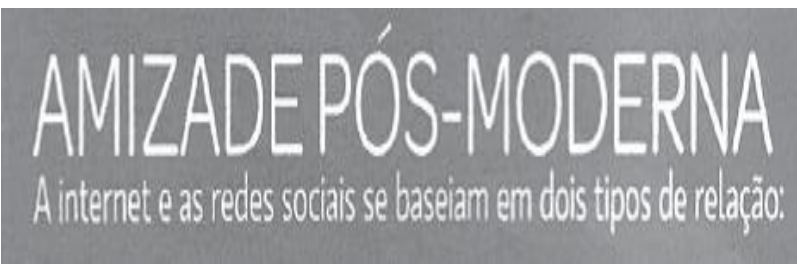
que essa referência fique clara, é apresentado um texto explicativo "A internet e as redes sociais se baseiam em dois tipos de relação:”, apresentado como uma espécie de subtítulo (ou lead) localizado abaixo do título.

Os dois tipos de amizade apresentados são: a amizade simétrica (recíproca e que promove privacidade) e a amizade assimétrica (não recíproca, mas torna mais fácil "a formação de laços").

O texto da amizade simétrica declara que ela "É recíproca: se eu quiser ter você como amigo e acessar o seu perfil, você precisa autorizar o pedido e se tornar meu amigo também". Esse conceito é evidenciado pela parte superior do texto, que traz uma

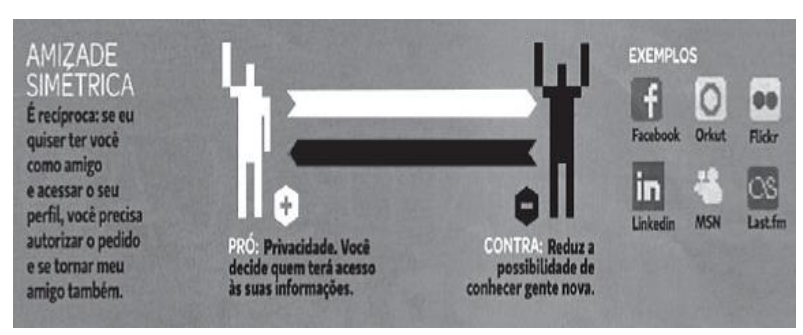
ilustração de duas pessoas ligadas por duas setas, que simbolizam a reciprocidade entre elas, mostra também suas vantagens e desvantagens (pró e contra) e traz alguns exemplos de redes sociais que se encaixam nesse perfil de amizade (Facebook, Orkut, Flickr, Llinkedin, MSM, Last.fm).

No plano de amizade simétrica, a composição representacional é realizada pelo processo conceitual simbólico: a figura de cor branca representa o "eu" da pessoa ("se eu quiser ter você como amigo") que envia o pedido de amizade, por isso está acenando

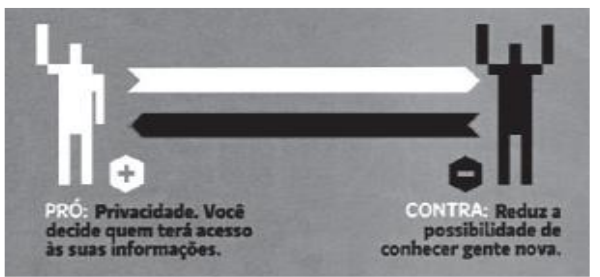
com a mão, o que simboliza simpatia. Esse "boneco" representa a privacidade, pois "Você decide quem terá acesso às suas informações", por isso ele representa a vantagem de uma amizade simétrica; quanto à figura de cor preta, representa o "você" ("você precisa autorizar o pedido e se tornar meu amigo também"). Assim, ao não aceitar o pedido de amizade, o 
sujeito "Reduz a possibilidade de conhecer gente nova", por isso a configuração dos dois braços levantados representa, a meu ver, resistência a "conhecer gente nova", a desvantagem da amizade simétrica.

Quanto à amizade assimétrica, "Não é recíproca: eu posso adicionar ou seguir você sem precisar pedir permissão (e posso inclusive fazer isso sem que você saiba)". Esse conceito é exemplificado com a parte da

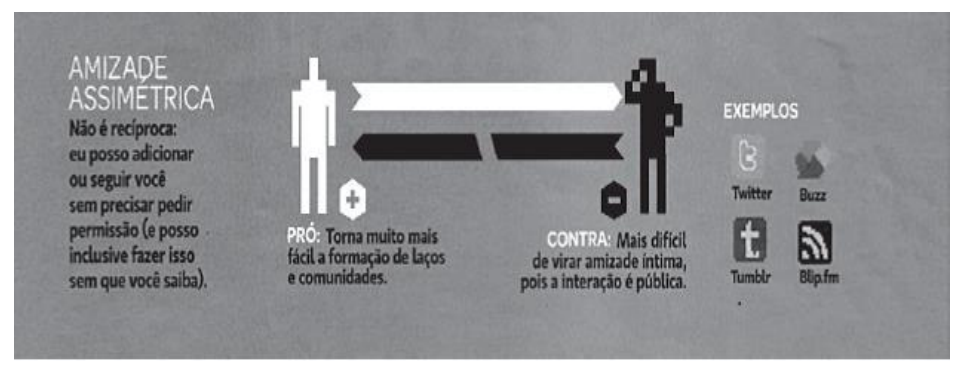
figura que está ao lado do texto verbal, que apresenta uma imagem da ligação entre duas pessoas que se "quebra" por não haver reciprocidade, e é ilustrado por exemplos de redes sociais em que esse tipo de amizade seja comum (Twuiter, Buzz, Tumblr, Blip.fm).

No plano de amizade assimétrica, a composição representacional também é realizada pelo processo conceitual simbólico: a figura de cor branca representa o "eu",

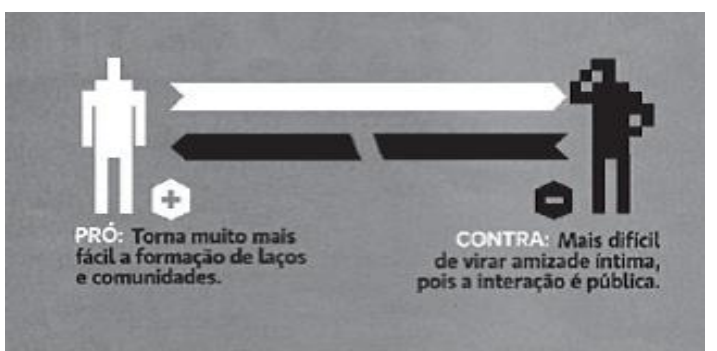
que pode adicionar ou seguir "você" sem pedir permissão, por esse motivo o boneco está estático, simbolizando que não precisa haver interação inicial entre os dois para que se forme uma amizade virtual. Esse conceito representa a vantagem da amizade assimétrica, pois “Torna muito mais fácil a formação de laços e comunidades".

Quanto à figura de cor preta, traz uma mão na cabeça e a outra na cintura, o que me permite considerar uma pessoa pensando se vai ou não formar ou manter laços de amizade com a outra. Esse boneco representa a desvantagem da amizade assimétrica, o contra: "Mais difícil de virar amizade íntima, pois a interação é pública.

\section{Os valores da informação}

multimodal são compostos pelas imagens ao centro (as figuras de pessoas interagindo) que estão em primeiro plano por estarem em maior destaque. Essas figuras representam as "personagens" citadas nas partes verbais ("eu"

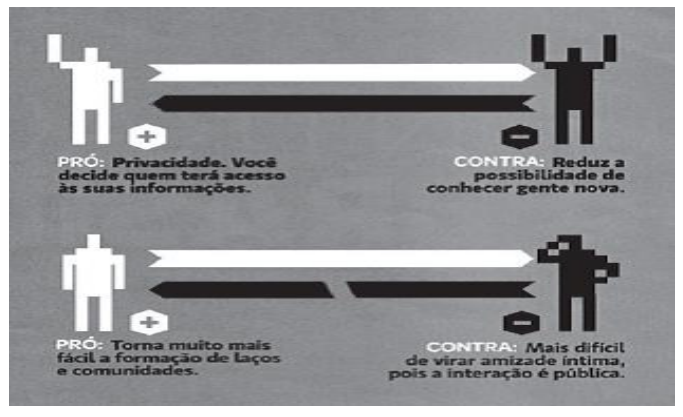
e "você"): do lado direito, observo duas figuras de cor branca, que representam as 
vantagens (pró) dos dois tipos de relação; e, do lado esquerdo, duas figuras de cor preta que representam as desvantagens (contra) dos dois tipos de amizade.

O que caracteriza a estrutura narrativa no texto visual é a presença de vetor (ou vetores), pois há traços que indicam direcionalidade (as setas brancas e pretas), linhas que representam a reciprocidade ou não dos tipos de amizade virtual. Essa direcionalidade, nesse caso, causa reciprocidade (na amizade simétrica) e falta de reciprocidade (na amizade assimétrica).

Analisando a figura superior do lado direito, percebo que a seta branca representa a amizade do boneco branco com o boneco preto (representa a vantagem). A seta preta representa a reciprocidade da amizade do boneco preto com o branco, que, pela reciprocidade, diminui as possibilidades de conhecer novas pessoas (representa a desvantagem).

Quanto à figura inferior, a seta branca representa a amizade do boneco

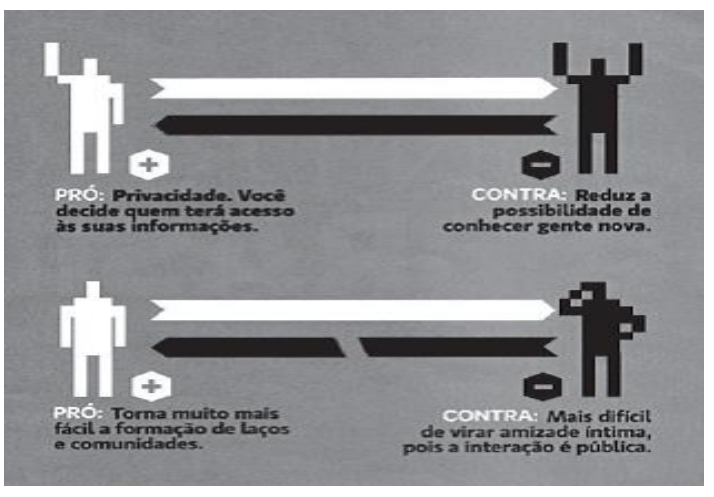
branco com o preto (representa a vantagem) e a seta preta, que representaria a amizade do boneco preto, foi quebrada, pois não há reciprocidade na amizade assimétrica (representa a desvantagem), o que dificulta que uma amizade se torne íntima.

Posto isso, entendo que as cores branco e preto apresentam significados distintos na imagem central do texto não verbal. A saber: a cor branca representa as vantagens dos dois tipos de amizade, e a cor preta representa as desvantagens. Considera que essas duas cores diferentes foram utilizadas para que se confirmasse a diferenciação entre as vantagens e as desvantagens de cada tipo de amizade.

O texto 3 relaciona-se com algumas competências de leitor multiletrado: ele precisa ser um leitor usuário funcional, porque o texto demanda conhecimento prático sobre algumas redes sociais que tenham os dois tipos de amizade (simétrica e assimétrica) e para que entenda as diferenças entre as duas; e ele precisa ainda ser um leitor criador de sentidos, porque a questão apresenta um texto diversificado e com tecnologias operantes (o texto 3 se refere à tecnologia, à amizade nas redes sociais e utiliza linguagem produzida no meio digital como a composição textual e os exemplos de logotipos de redes sociais). 
A partir das competências da matriz de referência do Enem, identifico o predomínio da habilidade H30. Ela avalia a capacidade de relacionar as tecnologias de comunicação e informação ao desenvolvimento das sociedades e ao conhecimento que elas produzem (neste caso, o desenvolvimento das sociedades relacionado às tecnologias de comunicação e informação está representado nos textos "prós" e no comando da questão, no trecho "Da mesma forma que em outras áreas, a internet também inovou nas maneiras de vivenciar a amizade"). A questão relaciona tipos de amizade pós-moderna nas redes sociais por meio de infográfico com diversas leituras e inferências possíveis.

A habilidade 30 é avaliada nessa questão a partir do texto motivador até o comando da questão e suas alternativas. No comando da questão, há um trecho que fortalece a importância da amizade, seja ela simétrica ou assimétrica: ios sao um dos principais indicadores de bem-estar na vida social das pessoas. Da mesma foma que en outras áreas, a internet também inovou as maneiras de vivenciar a amizade. Da leitura do infográfico, depreendem-se dois tipos de amizade vitual, a simétrica e a assimética, ambas com seus prós e contras. Enquanto a primeira se basela na relaçäo de reciprocidade, a segunda “Os amigos são um dos principais indicadores de bem-estar na vida social Q 0 reduz onúmero de amigos virtuais, ao limitar o acesso à rede. (3) parte do anonimato obrigatório para se difundir.

O reforça a configuraçăo de laços mais profundos de amizade.

(D) faclitia a interaçäa entre pessoas em virtude de interesses comuns.

$\exists$ tem a responsabilidade de promover a proximidade fisica. das pessoas”. Para convencer o leitor de que a amizade pós-moderna é interessante, há o trecho "Da mesma forma que em outras áreas, a internet também inovou as maneiras de vivenciar a amizade".

Os excertos citados, a meu ver, estimulam o desenvolvimento da sociedade por meio da escolha de amizades virtuais (amizade pós-moderna), de acordo com o seu perfil de relacionamento, visto que não foi constatado que uma amizade é mais vantajosa que a outra, pois cada uma delas possui vantagem e desvantagem. Essas amizades são concretizadas através de tecnologias de comunicação e de informação.

Quanto às alternativas da questão, o estudante deve selecionar o que apresenta caraterísticas da amizade assimétrica. Para isso, o leitor deve atentar às descrições da amizade assimétrica da segunda linha do texto com seu pró e contra. Percebo que, apesar de o texto 3 ser sofisticado por apresentar semioses detalhadas e significativas, para responder a essa questão, o indispensável é ler a parte verbal do texto, pois a questão não requer leitura do significado imagético dos bonecos e das setas, por exemplo. 
Nesse sentido, penso que vale a pena até mesmo considerar que, no caso deste texto-base, o uso de várias semioses dificultou a resolução da questão, visto que apenas as informações verbais são requeridas na avaliação. Destaco ainda que, nesse texto, a

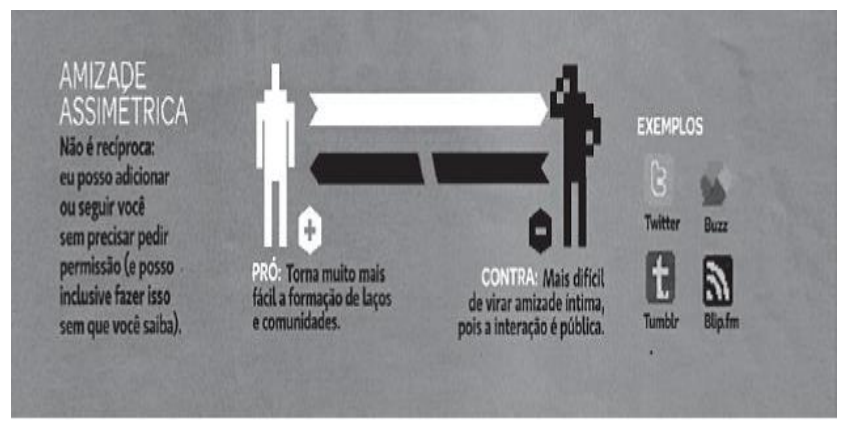
utilização dos pronomes "eu" e "você" possibilita mais proximidade e empatia entre o texto e o leitor. E o uso de imagens representativas das várias redes sociais usadas pelo público no meio digital ajuda a reconhecê-las mais rapidamente.

Por fim, a questão 107 de 2011 requer que o leitor esteja habilitado a compreender textos multimodais complexos, como o infográfico exibido, e esteja atualizado a ponto de reconhecer os dois tipos de amizade pós-moderna que foram apresentados e alguns exemplos de redes sociais referentes a eles. Por isso, os estudantes devem se desafiar a ler textos com linguagens mais sofisticadas e com diversos recursos linguísticos e argumentativos para que, ao encontrar esse tipo de texto, estejam preparados para realizar compreensões e interpretações a partir dos dados textuais e de suas experiências como leitores.

Passo agora à análise da questão relativa à prova de 2012, a quarta questão aqui analisada.

Figura 11 - Texto 4 - Questão 103/2012

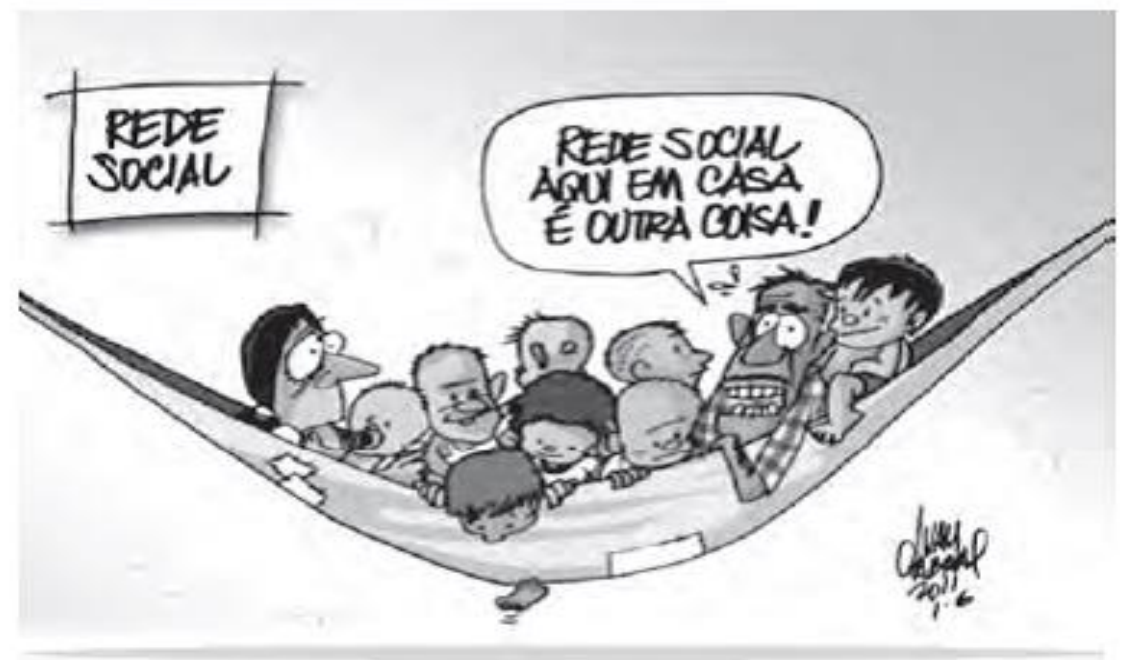

Disponivel ern: wuwivancabral.com. Acesso em: 27 fev. 2012. 
O efeito de sentido da charge e provocado pela combinaçāo de informaçōes visuais e recursos linguísticos. No contexto da ilustraçāo, a frase proferida recorre à

(A) polissemia, ou seja, aos múltiplos sentidos da expressāo "rede social" para transmitir a ideia que pretende veicular.

B ironia para conferir um novo significado ao termo "outra coisa".

C homonímia para opor, a partir do advérbio de lugar, o espaço da populaçāo pobre e o espaço da populaçāo rica.

D personificação para opor o mundo real pobre ao mundo virtual rico.

E antonimia para comparar a rede mundial de computadores com a rede caseira de descanso da familia.

O texto 4 é uma charge retirada do site do próprio autor, um chargista e mestre em educação. No texto observo o uso de modalidades, como imagem (com ênfase nas expressões faciais) e texto verbal, e ainda a mesma expressão (rede social) utilizados em diferentes contextos.

A composição representacional é realizada por meio do processo conceitual da expressão "REDE SOCIAL" escrita à esquerda do texto, pois ela representa o título e se refere ao contexto tecnológico.

Há ainda o processo narrativo de reação representado pela direção do olhar e pela expressão facial do participante que identifico como o pai. O olhar direto do participante "pai" para o viewer (leitor multimodal) configura composição interacional pela demanda de troca de olhares; e, pela posição frontal desse participante, há maior

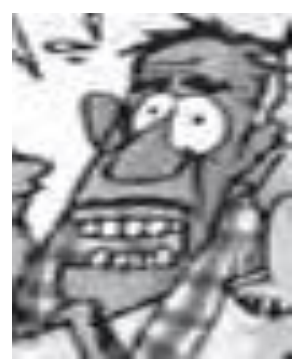
envolvimento do texto com o viewer e menor distância social pela proporção da visão do texto - visto de perto.

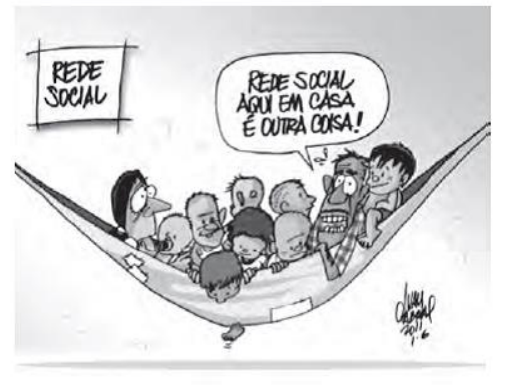

Os valores informacionais do texto 4 são percebidos pela posição em que as duas partes verbais estão: "REDE SOCIAL" do lado esquerdo, por isso é a informação dada, a rede social dos meios digitais, infere-se que seja conhecida pelo leitor; e a declaração: "REDE SOCIAL AQUI EM CASA É OUTRA 
COISA" juntamente com o texto não verbal configura a informação nova, um novo contexto para a expressão "rede social", explicado pela imagem de uma família dentro de uma mesma rede, o que fez com que a rede se tornasse social. Há também a saliência, em primeiro plano, por estar em maior estaque, da figura da rede que é social pelo fato de a família inteira utilizá-la em um mesmo momento.

Sobre as competências dos Multiletramentos, predominam os requisitos de habilidades de um leitor: analista crítico, pela referência a informações que se infere serem conhecidas, apesar de serem ressignificadas em outros contextos históricos, sociais e culturais de produção de significado como a "rede social" dos meios digitais; criador de sentidos, pois há demanda de entendimento de texto multimodal e com contextos relevantes; e transformador, visto que o texto revelou novos modos de demonstrar conteúdos anteriormente aprendidos, nesse caso, a utilização de uma expressão conhecida, rede social, em outro contexto totalmente inovador.

Quanto às habilidades da matriz de referência de LCT do Enem, há a prevalência da: H21 - reconhecer, em textos de diferentes gêneros (nesse caso, a charge), recursos verbais e não verbais para criar comportamentos e hábitos. Aqui depreendo que o sentido atribuído, no contexto, à expressão "rede social" apresenta uma nova interpretação, pois, enquanto a "rede social" usual se refere a meios digitais (o que traz ideia de distância), a segunda "rede social" faz referência à proximidade e ao contato direto (o que configura uma crítica social, por meio de metáfora, que infere a ideia de novos hábitos, como, por exemplo, mais momentos compartilhados em família).

O texto 4 requer o conhecimento de estruturas e funções da língua portuguesa, bem como do gênero charge, para responder à questão corretamente. Requer ainda a atenção à diferenciação da expressão "rede social", por ser utilizada em dois contextos e ter sentido diferente e em cada um deles.

A questão propõe "a combinação de informações visuais e recursos linguísticos" para analisar a função do período "Rede social aqui em casa é outra coisa!" quanto aos recursos linguísticos predominantes nesse contexto. A partir do comando da questão, acentuo que o estudante deve reconhecer os dois sentidos da expressão "rede social", assim selecionará a alternativa correta. A alternativa $\mathbf{A}$ trata dos múltiplos sentidos dessa expressão no texto. As demais alternativas apresentam ideias incorretas: a alternativa B destaca o excerto "outra coisa" como tendo um novo significado, quando o termo que adquire novo significado é o termo "rede social"; a $\mathbf{C}$ trata de oposição entre 
"o espaço da população pobre e o espaço da população rica", o que não faz sentido por

O efeito de sentido da charge é provocado pela combinaçāo de informaçōes visuais e recursos linguísticos. No contexto da ilustração, a frase proferida recorre à

(A) polissemia, ou seja, aos múltiplos sentidos da expressāo "rede social" para transmitir a ideia que pretende veicular.

B ironia para conferir um novo significado ao termo "outra coisa".

C homonímia para opor, a partir do advérbio de lugar, o espaço da população pobre e o espaço da população rica.

D personificação para opor o mundo real pobre ao mundo virtual rico.

E antonímia para comparar a rede mundial de computadores com a rede caseira de descanso da família. não ser o tema tratado no texto, pois a comparação é entre os dois sentidos de "rede social" como meio digital e como uma rede (objeto) compartilhada; sobre esse mesmo ponto de vista.

A alternativa $\mathbf{D}$ também aborda pobre versus rico, o que não faz sentido pela mesma explicação da alternativa anterior; e a última, a alternativa $\mathbf{E}$, refere-se à comparação entre duas redes

diferentes (rede de computadores e rede caseira de descanso), quando, na verdade, o texto versa sobre rede social e rede caseira.

Os significados textuais são compostos pelas modalidades verbal e não verbal, que se complementam para dar sentido ao texto 4 e, assim, à questão. Portanto, o leitor deve conhecer o primeiro sentido da expressão "rede social" (o título), caso contrário, ele não compreenderá os múltiplos sentidos que ela pode apresentar no texto motivador. Precisa, ainda, entender que o contexto é elemento definidor do sentido da expressão, e que esse sentido pode variar para atender a demandas comunicativas diversas.

Figura 12 - Texto 5 - Questão 131/ 2013

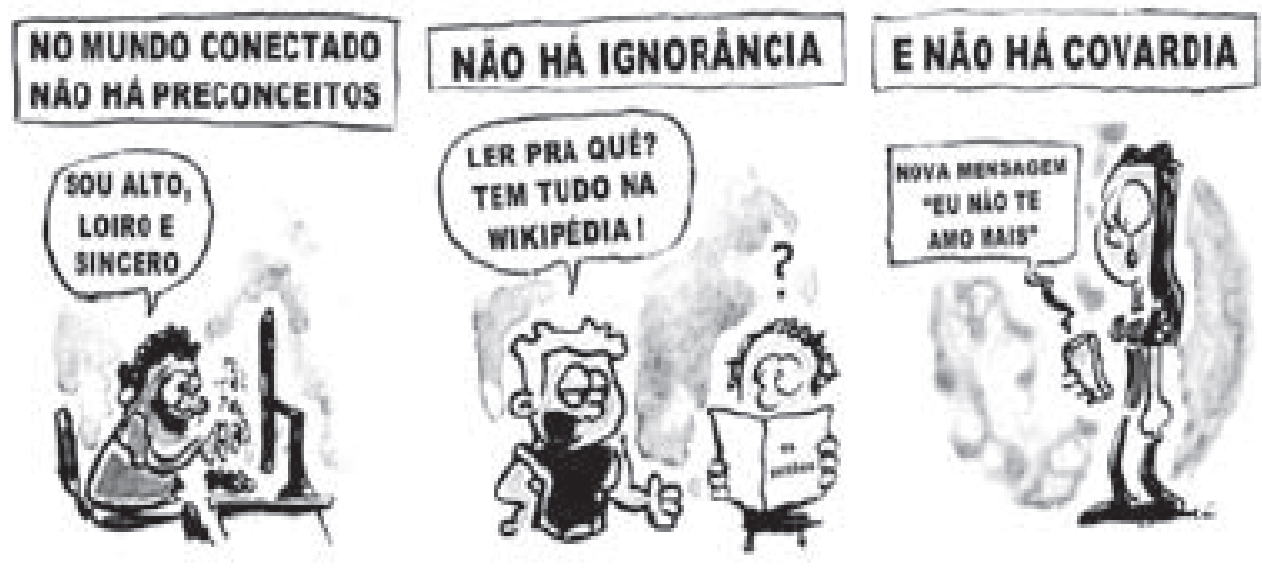

CURY, C. Disponivel em: http:/tirasnacionais. blogspot.com. Acesso em: 13 nov. 2011. 


\section{A tirinha denota a postura assumida por seu produtor frente ao uso social da tecnologia para fins de interação e de informaçāo. Tal posicionamento é expresso, de forma argumentativa, por meio de uma atitude}
(A) crítica, expressa pelas ironias.
B resignada, expressa pelas enumeraçōes.
C indignada, expressa pelos discursos diretos.
D agressiva, expressa pela contra-argumentação.
E alienada, expressa pela negaçāo da realidade.

O texto 5 é uma tirinha que trata do uso social da tecnologia digital para quesitos como interação e informação. Para melhor compreensão, há, em cada quadrinho, o tema (texto na parte superior) e em seguida o exemplo com as ações e as falas das personagens que retratam essa realidade.

Verifico a presença da composição representacional pelos participantes interativos do texto. Mesmo que eles nem sempre estejam interagindo com pessoas do texto, eles interagem com o viewer (leitor do texto multimodal), pois representam as pessoas que utilizam os meios sociais perceptíveis na tirinha (computador e celular), as mídias digitais e as redes sociais que são perceptíveis pelas falas dos participantes.

Ainda sobre a representação, há o processo conceitual simbólico exibido pelas personagens, as quais vivenciam o que não deveria existir no contexto digital, portanto elas simbolizam os usuários do "mundo conectado". Essas personagens representam pessoas da 'vida real' que utilizam os meios e as redes digitais e que vivenciam as situações apresentadas na tirinha.

A composição do significado no espaço é percebida pelos valores informacionais de ideal e real. $\mathrm{O}$

ideal é apresentado na parte $\begin{aligned} & \text { NO MUNDO CONECTADO } \\ & \text { NÁO HA PRECONCEITOS }\end{aligned}$ NÄO HÁ IGNORÁNCIA ENÃO HÁ COVARDIA
superior do texto com os trechos: "NO MUNDO CONECTADO NÃO HÁ
PRECONCEITOS", "NÃO HÁ IGNORÂNCIA" "E NÃO HÁ COVARDIA", esses
excertos mostram como seria a mundo conectado ideal. Por outro lado, na parte inferior, o real, a realidade, é apresentado com os trechos: "Sou alto, loiro e sincero", "Ler pra quê? Tem tudo na Wikipédia!" e "Nova mensagem: 'Eu não te amo mais"”. Esses trechos retratam a realidade - o contrário do ideal que deveria existir e que ocorre muito no mundo conectado: o preconceito, a ignorância e a covardia. 
Para complementar a composição do significado, há saliência, em primeiro plano, dos títulos de cada quadrinho - pois estão na parte superior, em caixa alta e em fontes maiores que os outros textos; e, em segundo plano, por estarem em evidência menor que os títulos apresentados, os balões de texto e as ações mostradas pelas personagens, pois retratam exemplos concretos dos títulos que estão em maior destaque.

Quanto às competências do leitor multiletrado, percebo que há requisito de habilidade de um leitor: criador de sentidos, pois, no texto 5, há demanda de compreensão de textos multimodais (aqui pela presença de elementos verbais e não verbais) e de elementos de inferência (como a ironia); e com tecnologias operantes (que é inclusive o tema do texto); transformador, visto que há novas formas de demonstrar conteúdos anteriormente aprendidos (o uso social da tecnologia exemplificado pelas situações vividas nos exemplos).

Partindo das habilidades da matriz de referência do Enem, a habilidade que fica em evidência na avaliação da questão é a H4: reconhecer posições críticas aos usos sociais que são feitos das linguagens e dos sistemas de comunicação e informação (a posição crítica foi estabelecida pela ironia do texto ao demostrar, pelas ações das personagens, que tudo o que não era para ter no mundo conectado estava presente ou ainda pela apresentação da idealização excessiva das relações nas redes sociais).

A questão refere-se à "postura assumida por seu produtor ao uso social da tecnologia para fins de interação e de informação". O posicionamento que o produtor do texto assume é crítico, o que foi expresso por ironias, pelo fato de existir o que não era para existir no mundo conectado (preconceito, ignorância e covardia). Isso evidencia que o uso da tecnologia pode desencadear impactos sociais nas relações por considerar que, em nossa cultura, corresponder a um padrão idealizado de beleza (ser alto e loiro) significa ser socialmente A tirinha denota a postura assumida por seu produtor frente ao uso social da tecnologia para fins de interação e de informação. Tal posicionamento é expresso, de forma valorizado, pois uma pessoa que tem "cultura" (lê bastante) é valorizada

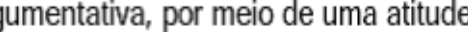

(A) crítica, expressa pelas ironias.

B resignada, expressa pelas enumeraçōes.

(C) indignada, expressa pelos discursos diretos. socialmente; e, ainda, ser uma pessoa D agressiva, expressa pela contra-argumentação. (૯) alienada, expressa pela negação da realidade. corajosa (e falar face a face) também está nos padrões aceitos socialmente. Assim o texto demonstra, de forma irônica, que algumas características, como preconceito, ignorância e covardia, não são agradáveis 
para existir na interação social tecnológica, revelando-as negativamente com os exemplos da tirinha.

$\mathrm{Na}$ questão analisada, observo que as personagens vivem situações bem diferentes das esperadas e dos ideais no mundo conectado. Esse texto requer do leitor um entendimento mais que meramente literal, pois é necessário que compreenda a posição crítica adotada pelo autor do texto para chegar à resposta correta da questão. Além disso, para a compreensão completa do texto 5, o leitor deve ter bom raciocínio lógico e estar habilitado a fazer inferências a partir de situações dadas, por isso é necessário incentivar leituras sofisticadas, de livros com linguagem mais complexa, por exemplo, para que o estudante, ao se deparar com esse tipo de texto, esteja apto a desenvolver diversos raciocínios.

Figura 13 - Texto 6 - Questão 131/ 2014

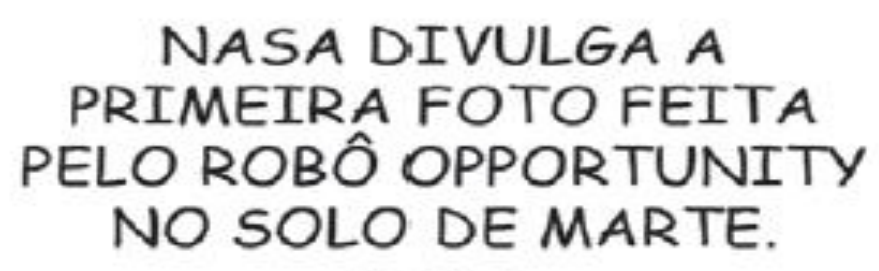

VEJA:

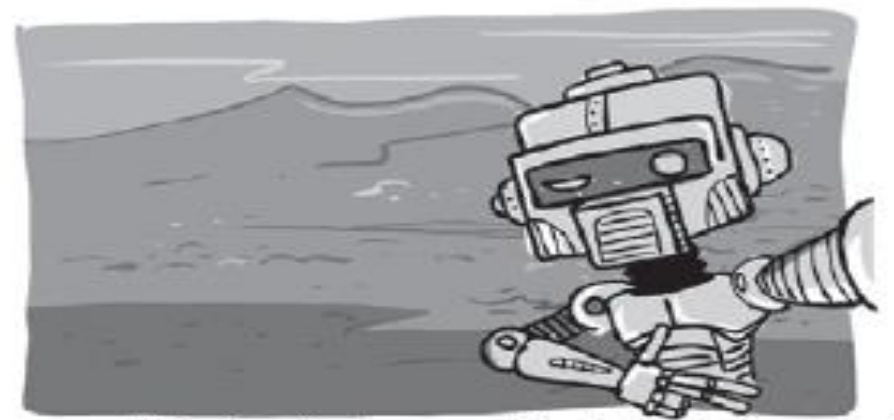

WILL. Disponivel em: www.willtirando.com_br. Acesso em: 7 nov. 2013.

Opportunity é o nome de um veículo explorador que aterrissou em Marte com a missão de enviar informaçỗes à Terra. A charge apresenta uma crítica ao(à)

A gasto exagerado com o envio de robôs a outros planetas.

B exploração indiscriminada de outros planetas.

C) circulação digital excessiva de autorretratos.

D vulgarização das descobertas espaciais.

E mecanização das atividades humanas. 
O texto 6 é uma charge que ressalta variadas tecnologias - como o robô, uma câmera fotográfica ou um celular com câmera - e critica a "circulação digital excessiva de autorretratos", mais conhecidos popularmente como selfies.

A composição representacional do texto é realizada por meio do participante interativo, o robô, que, por estar se fotografando, permite a impressão de que está olhando diretamente para o viewer; através do processo narrativo de ação nãotransacional, na qual há apenas um ator, o robô, que é também o protagonista; e, por meio do processo conceitual simbólico, no qual o robô simboliza as pessoas que registram vários momentos com selfies. A posição da mão com alguns dedos dobrados e a piscadela simbolizam o público jovem, que registra autorretratos divertidos.

Percebo que a saliência do robô como destaque da composição textual, em primeiro plano (por ser o elemento central do texto e por isso demanda maior atenção do viewer) e o texto verbal, em segundo plano, que explica a parte visual, compõem o significado espacial do texto.

Quanto à composição interacional, há: contato visual direto do participante robô com o leitor; pouca distância social, pois o participante é visto de perto (close shot), o que torna a relação íntima ou mais próxima com o leitor; e, pelo ângulo frontal e direto, maior envolvimento e igualdade de poder com o viewer.

A parte verbal do texto "NASA DIVULGA A PRIMEIRA FOTO FEITA PELO ROBÔ OPPORTUNITY NO SOLO DE MARTE. VEJA:" traz a explicação da imagem que aparece logo abaixo e permite, a meu ver, considerar os seguintes pontos: é preciso que o leitor saiba o que é a NASA (National Aeronautics and Space Administration ou Administração Nacional do

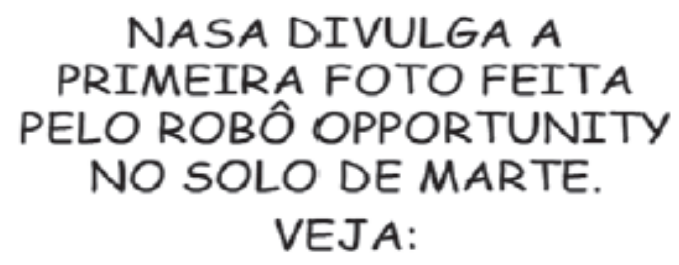

NASA DIVULGA A PRIMEIRA FOTO FEITA PELO ROBÔ OPPORTUNITY NO SOLO DE MARTE. VEJA:

Espaço e da Aeronáutica); é preciso também que o leitor tenha conhecimento de que OPPORTUNITY significa oportunidade, porque isso acentua que o robô "Oportunidade" aproveitou a oportunidade que teve para registrar a primeira foto e fez seu autorretrato. O trecho "SOLO DE MARTE" leva a acreditar que os autorretratos são tão populares que até em Marte eles existem.

Quanto às competências do leitor multiletrado que se relacionam com questão, as habilidades que mais se sobressaem na questão são as de um leitor: usuário funcional, pois o texto requer conhecimento técnico, propõe conhecimento do 
significado de NASA e do popular autorretrato; analista crítico, visto que no texto há uma seleção prévia de conteúdos, os quais se infere serem conhecidos, como NASA e Marte, por exemplo; criador de sentidos, por haver demanda de conhecimento de textos multimodais, como esse que contém elementos verbais e não verbais, e com tecnologias operantes (o texto trata do tema tecnologia), no texto 6 representadas pelo próprio robô tirando seu autorretrato, ou seja, tecnologia (robô) interagindo com tecnologia (autorretrato).

Em se tratando das habilidades da matriz de referência de LCT do Enem, destaco a $\mathrm{H} 30$ - relacionar as tecnologias de comunicação e informação ao desenvolvimento das sociedades e ao conhecimento que elas produzem. Essa habilidade é perceptível na imagem em que o robô registra seu autorretrato, possibilitando a compreensão de que o autorretrato está tão popular que até um robô em Marte conhece e consegue realizar esse tipo de fotografia. Isso retrata o conhecimento e o desenvolvimento tecnológico da sociedade.

A questão apresenta um comentário sobre o texto: “Opportunity é o nome de um veículo explorador que aterrissou em Marte com a missão de enviar informações à

Opportunity é o nome de um veículo explorador que aterrissou em Marte com a missão de enviar informaçốes à Terra. A charge apresenta uma crítica ao(à)

(A) gasto exagerado com o envio de robôs a outros planetas.

B exploração indiscriminada de outros planetas.

(C) circulação digital excessiva de autorretratos.

(1) vulgarização das descobertas espaciais.

$\Theta$ mecanização das atividades humanas.
Terra"; e discorre sobre um robô (criação tecnológica) que está no solo de Marte (planeta distante, que, para ser conhecido, requer meios de transporte que sejam tecnológicos, como o robô do texto, que

supostamente chegou até lá).

A crítica à circulação demasiada de autorretratos é feita pelo registro do robô no momento da chegada a Marte com uma selfie, o que permite compará-lo com as pessoas que registram muitos momentos por meio de autorretratos (vida pessoal e social), por isso o texto retrata uma crítica à "circulação digital excessiva de autorretratos" (alternativa C).

Observo que o texto 6 pressupõe que o leitor conheça o significado e o uso de algumas palavras apresentadas nele (como NASA, Marte e autorretrato), por isso utiliza-as para compor o significado com a inserção da imagem, que ilustra e completa o sentido textual. 
Considero também que, como uma parte do público que realiza as provas do Enem é formada por estudantes formandos do Ensino Médio, é normal que a prova use textos divertidos e com linguagem dos meios digitais, como o texto 6, para que o leitor tenha maior envolvimento e se identifique melhor com as questões.

Figura 14 - Texto 7 - Questão 118/ 2015

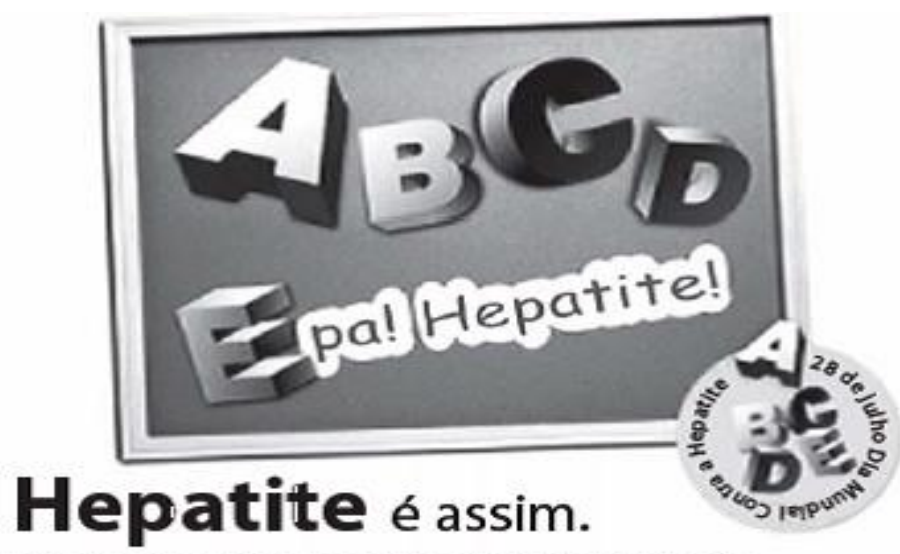

Pode aparecer onde menos se espera e em dinco formas diferentes.

É por isso que o Dia Mundial Contra a Hepatite está al para alertar voce. As hepatites A, B, C, De Etêm diversas causas e muitas formas de chegar até voce Mas, evitar isso é bem simples. Vocé só precisa ficar atento aos cuidados necessários para cuidar do maior bem que você tem: A SUA SAUUdE

Algumas maneiras de se prevenir:

- Vacine-se contra as hepatites A e B.

- Use água tratada e siga sempre as recomendaçōes quanto à restrição de banhos em locais públicos e ao uso de desinfetantes em piscin as. - Lave SEMPRE bem os alimentos como frutas, verduras e legumes. - Lave SEMPRE bern as máos após usar o toalete e antes de se alimentar.

- Ao usar agulhas e seringas, certifique-se da higiene do local e de todos os acessórios.

- Certifique-se de que seu médico ou profissional da saúde esteja usando a proteçăo necessária, como luvas e máscaras, quando houver a possibilidade de contato de sangue ou secreçb̄es contaminadas com o virus.

Disponivel em: htlp:/farm5 static. flickr.com. Acesso em: 26 out. 2011 (adaptado).

Nas peças publicitárias, vários recursos verbais e não verbais são usados com o objetivo de atingir o públicoalvo, influenciando seu comportamento. Considerando as informaçöes verbais e não verbais trazidas no texto a respeito da hepatite, verifica-se que

A O torn lúdico é empregado como recurso de consolidação do pacto de confiança entre o médico e a populaçăo.

(B) a figura do profissional da saúde é legitimada, evocando-se o discurso autorizado como estratégia argumentativa.

C uso de construçóes coloquiais e especificas da oralidade são recursos de argumentação que simulam o discurso do médico.

D a empresa anunciada deixa de se autopromover ao mostrar preocupação social e assumir a responsabilidade pelas informaçöes

* o discurso evidencia uma cena de ensinamento didático, projetado com subjetividade no trecho sobre as maneiras de prevenção. 
O texto 7 é um cartaz publicitário de conscientização para prevenção dos tipos de hepatite. Nele há muitas informações, talvez por isso ele inicia com humor para se aproximar do leitor e para despertar curiosidade e/ou interesse de continuar lendo.

A partir da observação da composição textual, constato que o quadro informativo dos tipos de hepatite (A B C D Epa! Hepatite!) insere-se no processo conceitual simbólico, por apresentar características diversas que trazem conceitos, como: as formas variadas das letras, suas cores (e sombreamento) e a ideia de movimento que elas transmitem. Essas características simbolizam as cinco formas diferentes da hepatite $(\mathrm{A}, \mathrm{B}, \mathrm{C}$, D, E). A expressão "Epa! Hepatite” simboliza um Basta! - chega de hepatite!, para que os leitores visualizem Hepatite é assim.

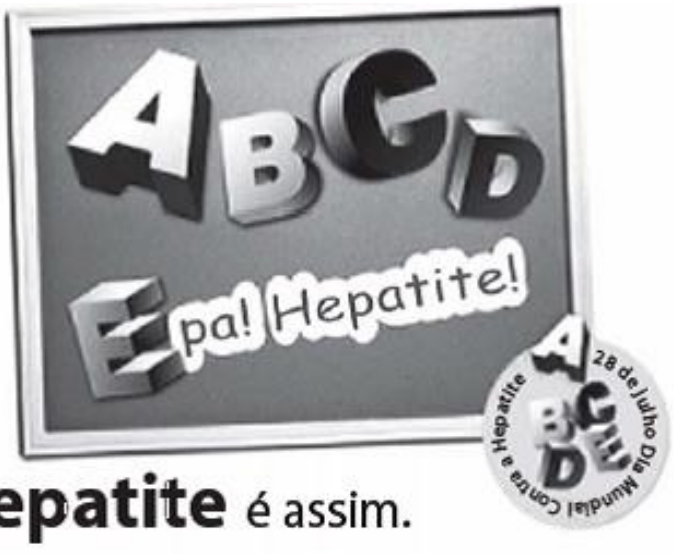
essa expressão popular "Epa! Hepatite" e se identifiquem melhor com o texto, tendo interesse para continuar a leitura até o final, visto que se trata de texto longo.

O texto do quadro “A B C D Epa! Hepatite!” está em evidência e maior destaque no texto, por isso, em primeiro plano. Ele é complementado pelo texto no canto inferior direito do quadro, em forma de círculo: “A B C D E 28 de julho Dia Nacional Contra a Hepatite". Essa parte textual é um esclarecimento quanto ao assunto principal (Hepatite), em vista disso ela demonstra o motivo pelo qual o texto está sendo veiculado e por que ele demanda atenção (porque é o "Dia Nacional Contra a Hepatite").

No segundo plano, com destaque em segundo lugar (pois em maior destaque está “A B C D Epa! Hepatite!" ), observo o vocábulo Hepatite do trecho "Hepatite é assim.", pois ele se destaca por estar em negrito e em fonte maior. Esse trecho juntamente com o próximo que segue "Pode aparecer onde menos se espera em cinco formas diferentes." permite perceber sentidos diversos: hepatite é assim, de cinco formas diferentes (esse texto confirma que, além das letras do quadro, as formas diferentes delas também simbolizam as cinco formas da hepatite); e ainda que a hepatite "é assim": "aparece onde menos se espera", essa expressão se aproxima do leitor, por ser uma expressão popular, haja vista que se trata de um cartaz de propaganda, por isso seu objetivo é atingir o maior número de leitores. 
O texto segue trazendo explicações sobre ele mesmo: "É por isso que o Dia Mundial Contra a Hepatite está aí para alertar você.”, salientando que há um dia

Hepatite é assim.

Pode aparecer onde menos seespera e em dinco formas diferentes.

É por isso que o Dla Mundial Contra a Hepatite está al para alertar vocé. As hepatites A, B, C, De Etêm diversas causas e muitas formas de dhegar até voce. Mas, evitar isso é bem simples. Vocé só precisa ficar atento aos cuidados necessários para cuidar do maior bem que voce tem: A SUA SAÚDEI

aparece "onde menos se espera").

O excerto "As hepatites A, B, C, D, e E têm diversas causas e muitas formas de chegar até você. Mas, evitar isso é bem simples. Você só precisa ficar atento aos cuidados necessários para cuidar do maior bem que você tem: A SUA SAÚDE!" sensibiliza o leitor por simular uma conversa que se dirige diretamente a ele, uma conversa marcada por formas diretas como as destacadas aqui em negrito.

Essa maneira direta de "conversar com o leitor" objetiva atingi-lo, sensibilizando-o para que ele se sinta responsável por evitar a propagação da hepatite, ficando atento aos cuidados necessários para cuidar do seu bem maior: "a sua saúde", que está realçada em caixa alta para que chame mais atenção do viewer.

Logo abaixo, dando continuidade aos significados da composição textual, no texto motivador, há indicações de maneiras de se prevenir contra os tipos de hepatite e a figura de uma profissional da saúde, que legitima o discurso, transformando-o em um discurso científico e confiável. A imagem da profissional da saúde traz características da

composição

Algumas maneiras de se prevenir:

- Vacine-se contra as hepatites A e B.

- Use água tratada e siga sempre as recomendaçōes quanto à restriçăo

de banhos em locais públicos e ao uso de desinfetantes em piscinas.

- Lave SEMPRE bem os alimentos como frutas, verduras e legumes.

- Lave SEMPRE bern as mảos após usar o toalete e antes de

se alimentar.

- Ao usar agulhas e seringas, certifique-se da higiene do local ede todos os acessórios.

- Certifique-se de que seu médico ou profissional da saúde esteja usando a proteçáo necessária, como luvas e máscaras, quando houver a possibilidade de contato de sangue ou secreçôes contaminadas com o virus. interacional, pois há contato visual direto com o viewer, o que diminui a distância social com 0 leitor e gera confiança, por simular uma conversa face a face com conselhos para evitar o contágio com o

vírus da hepatite.

Identifico como conselhos os tópicos apresentados ao lado da profissional da saúde pela sua postura (e olhar direto), pela posição em que o texto está (colocado ao redor da profissional, o que pode configurar como fala dela, que representa a fala da 
categoria da saúde) e pela forma verbal imperativa em "vacine-se", "use", "lave", e "certifique-se" (que significa fala direta com o interlocutor, nesse caso, o viewer, estudante que realiza a prova do Enem).

Algumas competências dos Multiletramentos que se sobressaem e se relacionam ao texto 7 são habilidades de um leitor: analista crítico, pois há seleção prévia de conteúdos que se pressupõe serem conhecidos pelos leitores (a hepatite e os seus tipos), mesmo que talvez não sejam tão difundidos; leitor criador de sentidos, pois o texto é multimodal e requer um leitor multiletrado que preste atenção em todas as semioses utilizadas; transformador, visto que há novas formas de demonstrar os tipos de hepatite por meio de texto descontraído e de expressões populares, como "Epa!" e "aparecer de onde menos se espera", tornando a linguagem mais simples e interessante para boa parte do público que realiza as provas do Enem.

A habilidade da matriz de referência do Enem predominante na avaliação da questão é, a meu ver, a H21: reconhecer, em textos de diferentes gêneros, recursos verbais e não verbais (como o quadro ilustrado pela "dança das letras", o texto verbal e a representação do profissional de saúde) utilizados com a finalidade de mudar comportamentos e hábitos (conscientizar e inserir hábitos de prevenção contra a doença).

A questão propõe uma leitura multimodal crítica para que se verifiquem os sentidos trazidos pelo texto, além de sua linguagem e seus recursos semióticos. A alternativa $\mathbf{B}$, que responde à questão, permite considerar o profissional da saúde como figura legitimadora e, de fato, é a presença da profissional de saúde que estabelece mais confiança aos conselhos dados. Quanto às demais alternativas, a A cita confiança “entre o médico e a população, mas, em momento algum, o texto se refere a médicos especificamente. Há apenas a figura de uma profissional da saúde, que pode ser uma médica, uma enfermeira ou uma técnica de enfermagem, etc. Sobre a alternativa $\mathbf{C}$, ela cita novamente o médico e afirma a utilização das construções coloquiais (que há no texto) relacionando-as à fala do médico, entretanto no texto não há margem para essa compreensão, pois não há a figura do médico.

A alternativa $\mathbf{D}$ também apresenta equívoco ao afirmar que a empresa anunciada assume a responsabilidade pelas informações, pois, ao apresentar a profissional da saúde, o texto o uso como meio par legitimar seu discurso, tornando-o verdadeiro e confiável como se fosse o próprio discurso da saúde. A última alternativa, E, cita 
"subjetividade" sobre as maneiras de prevenção, o que é um equívoco, visto que há imparcialidade nos conselhos de prevenção dados pela profissional da saúde, representados por trechos como "SEMPRE" e "certifique-se".

A linguagem do texto foi adaptada para simular uma conversa de forma que esclareça o leitor sobre o tema abordado, hepatite, para que haja conscientização. Para conscientizar o leitor sobre a prevenção da hepatite, o texto 7 recorre à linguagem direta, imperativa, mas, em alguns momentos, formal/técnica, pelo uso de vocábulos

Nas peças publicitárias, vários recursos verbais e não verbais são usados com o objetivo de atingir o públicoalvo, influenciando seu comportamento. Considerando as informações verbais e não verbais trazidas no texto a respeito da hepatite, verifica-se que

(4) o tom lúdico é empregado como recurso de consolidação do pacto de confiança entre o médico e a população.

(B) a figura do profissional da saúde é legitimada, evocando-se o discurso autorizado como estratégia argumentativa.

C o uso de construções coloquiais e especificas da oralidade são recursos de argumentação que simulam o discurso do médico.

(- a empresa anunciada deixa de se autopromover ao mostrar preocupação social e assumir a responsabilidade pelas informações.

(૯) o discurso evidencia uma cena de ensinamento didático, projetado com subjetividade no trecho sobre as maneiras de prevenção. como "toalete", "certifique-se da higiene", "secreções contaminadas". Por isso, pela linguagem utilizada, acentuo que esse texto é voltado para o público em geral, como estudantes que realizam as provas do Enem, candidatos formandos do ensino médio, graduando, graduados, pesquisadores, etc. $\mathrm{O}$ esclarecimento sobre os tipos de hepatite e suas formas de prevenção, por meio de linguagem

direta e imperativa, constitui significados mais próximos ao leitor, estabelecendo uma relação de empatia e identificação do leitor com as informações do texto;

Na questão 118 de 2015, há vários recursos verbais e não verbais utilizados como artifícios para conscientização e convencimento do leitor, como o quadro dos tipos de hepatite, a presença da profissional que expressa o discurso defendido pela saúde, etc. Assim o texto 7 requer que o leitor preste atenção na composição textual e nos recursos utilizados para o convencimento sobre a necessidade de prevenção e para sua conscientização sobre a doença. Destaco também que o candidato deve conhecer o tema (Hepatite), assim o texto será coerente para ele. Por isso, ressalto que as leituras diversas são fundamentais para que o estudante adquira vocabulário, conhecimentos e informações, dessa forma todo tipo de leitura é relevante, desde gibis e panfletos de supermercado a cartazes informativos e livros didáticos. 
Figura 15 - Texto 8 - Questão 109/ 2016

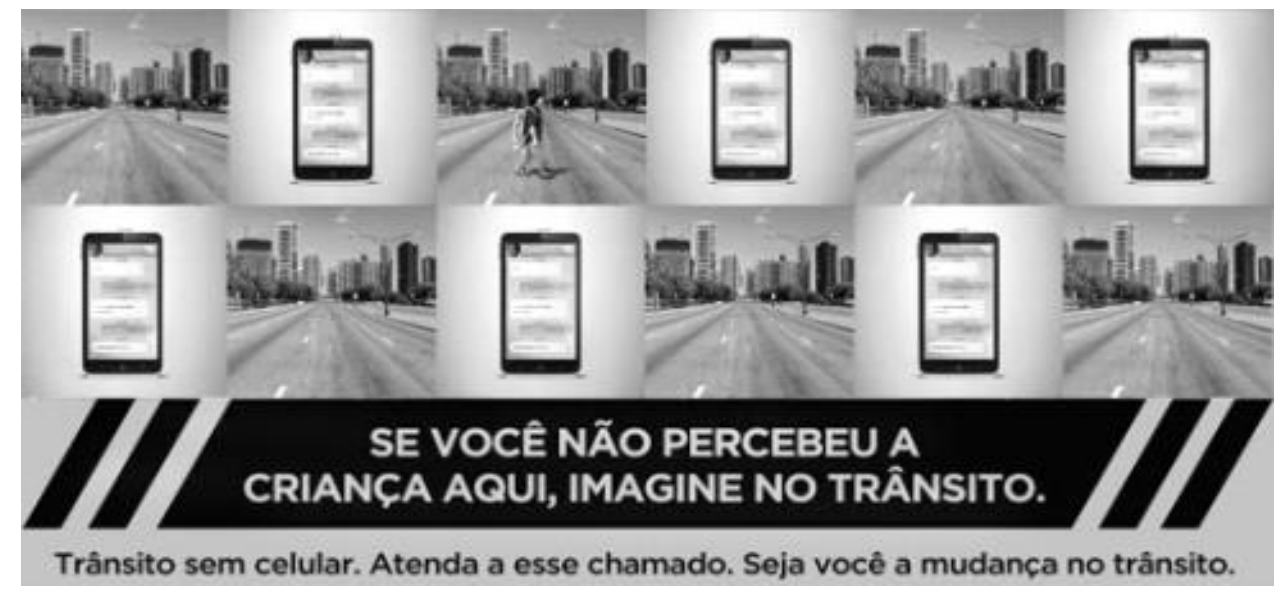

Disponivel em: www.paradapelavida.com.br. Acesso em: 15 nov. 2014.

Nesse texto, a combinação de elementos verbais e não verbais configura-se como estratégia argumentativa para

A manifestar a preocupação do governo com a segurança dos pedestres.

B associar a utilização do celular às ocorrências de atropelamento de crianças.

C orientar pedestres e motoristas quanto à utilização responsável do telefone móvel.

(D) influenciar o comportamento de motoristas em relação ao uso de celular no trânsito.

E alertar a população para os riscos da falta de atenção no trânsito das grandes cidades.

O texto 8 é um recorte de um site governamental, o qual promove diversas campanhas relacionadas ao trânsito seguro. Esse texto multimodal está apresentado em forma de texto único, unindo parte verbal e não verbal em um mesmo enquadramento. A composição textual simula o leitor (viewer) no ângulo do motorista, por meio do processo simbólico e ângulo frontal, permite maior envolvimento do viewer com o texto e menor distância social, por assumir papel de protagonista que se vê em posição de decisão ao ler o texto.

A partir da GDV, de Kress e van Leuween (2006), destaco a composição dos significados no espaço dos elementos e os valores informacionais: os não verbais estão lado a lado (configurando mesmo valor), o que nos remete à importância que é dada ao celular pelo motorista a partir do momento em que ele está em posse do aparelho; e ainda que, olhando para os dois ao mesmo tempo (celular e trânsito), o motorista não se concentra em nenhum deles, o que configura falta de atenção a ponto dele não enxergar uma pessoa na sua frente. 
As várias imagens intercaladas entre celular e pista também remetem a um olhar superficial e/ou a uma sequência de "olhadas" alternadas entre a pista e o celular, e que, em uma delas, há uma criança (que representa os pedestres) que não foi vista pelo

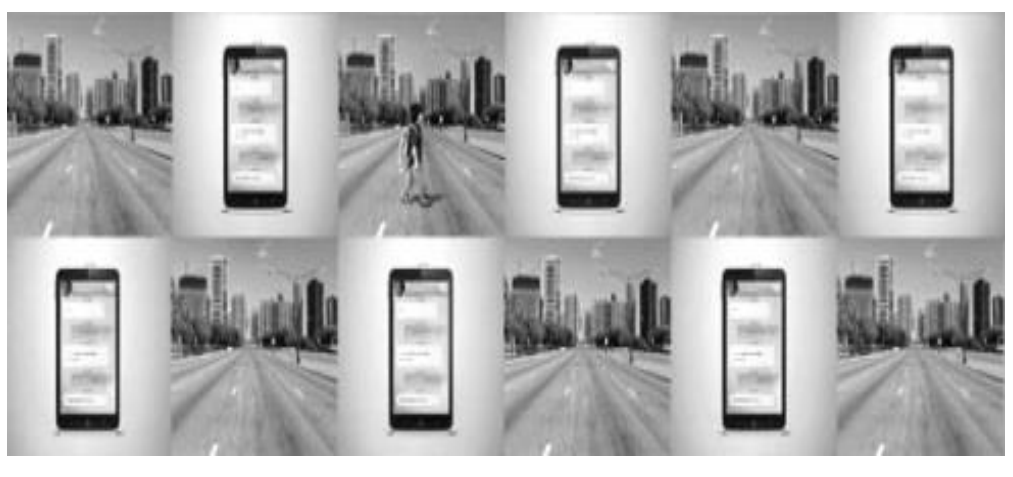
motorista por sua falta de atenção ao trânsito. Aqui percebo a estrutura conceitual: a criança (uma parte), a qual representa os pedestres (o todo) por meio desse processo analítico, explicado pela GDV.

Ao passo que a parte textual verbal destacada em caixa alta "SE VOCÊ NÃO PERCEBEU A CRIANÇA AQUI, IMAGINE NO TRÂNSITO.” e escrita em uma faixa preta - a qual, pelas faixas brancas em cada extremidade, faz referência à faixa de

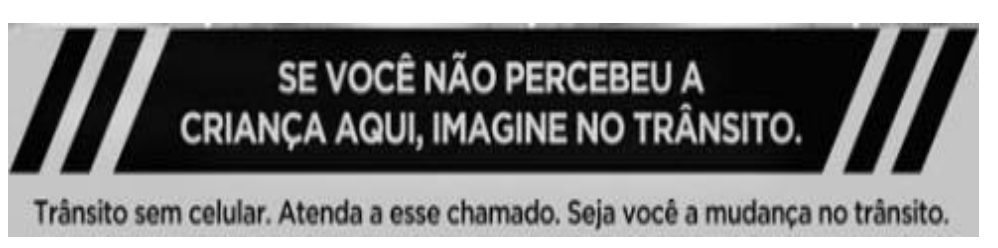
pedestres - adverte para a atenção exclusiva que o trânsito demanda e traz reflexão quanto à imagem da criança que, por estar embaçada, não permite certeza para afirmar se é ou não uma criança mesmo.

Quanto ao texto menor e, por isso com menor destaque, "Trânsito sem celular. Atenda a esse chamado. Seja você a mudança no trânsito.”, há, por meio de metáfora, um convite ao motorista: que "atenda" a esse chamado (trânsito sem celular) e não que "atenda" à chamada do celular no trânsito. O texto também sensibiliza o leitor e deposita nele a responsibilidade pela mudança no trânsito ao chamá-lo diretamente por meio de linguagem imperativa: "Seja você a mudança no trânsito.".

Algumas competências dos Multiletramentos que se evidenciam no texto 8 são habilidades de um leitor: criador de sentidos, pois o texto requer um leitor multiletrado capaz de compreender texto multimodal (com composição interacional com o leitor, utilização de celular, e retratação de pista real para convencimento); transformador, pois, no texto, há premissa de transformação de teorias em novas práticas (atender ao chamado de não atender o celular), baseadas em valores e objetivos em determinados contextos sociais (para um trânsito seguro). 
Observo que a questão 109 de 2016 avalia a habilidade H21: reconhecer, em textos de diferentes gêneros, recursos verbais e não-verbais utilizados com a finalidade de criar e mudar comportamentos e hábitos (no caso, o comportamento imprudente do motorista ao atender o celular no trânsito).

A questão requer do leitor posicionamento crítico para identificar qual a finalidade da "estratégia argumentativa" do texto, citada no comando. A partir da leitura e da análise dos recursos linguísticos utilizados, aponto que o objetivo do texto é conscientizar o viewer para um trânsito seguro e sem celular.

Para o convencimento do público, foram utilizadas algumas estratégias argumentativas como a intimidação realizada pela conversa direta com o leitor, através do vocativo; e pela presença de uma criança no meio da pista, que causa maior sensibilização ao leitor que um adulto, por exemplo.

Após a leitura do texto com atenção nos recursos linguísticos utilizados e na composição dos significados do texto, evidencio que o estudante selecionará a alternativa correta, a $\mathbf{D}$, que revela o objetivo para o qual o texto se volta:

Nesse texto, a combinação de elementos verbais e não verbais configura-se como estratégia argumentativa para

(4) manifestar a preocupação do governo com a segurança dos pedestres.

B associar a utilização do celular às ocorrências de atropelamento de crianças.

C orientar pedestres e motoristas quanto à utilização responsável do telefone móvel.

(D) influenciar o comportamento de motoristas em relação ao uso de celular no trânsito.

(E) alertar a população para os riscos da falta de atenção no trânsito das grandes cidades.

"influenciar o comportamento de motoristas em relação ao uso de celular no trânsito".

A composição do texto motivador requer do leitor uma experiência multiletrada, pois se trata de um texto retirado de uma campanha de trânsito, o que me permite afirmar que esse texto ou pelo menos o assunto dele é conhecido.

O que percebo, após as análises, é que há a necessidade de os estudantes utilizarem sua experiência como leitores, a partir de conhecimentos linguísticos e extralinguísticos adquiridos ao longo de sua vida escolar e extraescolar, para compreenderem a composição textual e seus significados. Finalizada a parte da análise do corpus selecionado, passo em seguida para minhas considerações finais. 


\section{CONSIDERAÇÕES FINAIS}

Nesta pesquisa meu objetivo principal foi analisar questões das provas de Língua Portuguesa do Enem à luz das teorias de Multiletramentos e de Multimodalidade para verificar a ocorrência de textos multimodais e as habilidades de leitura que são requeridas para a compreensão desses textos. Para alcançar esse objetivo, estabeleci três questões principais:

1. Que tipos de textos multimodais estão presentes nas questões das provas de Língua Portuguesa do Enem?

2. Como os textos multimodais são utilizados para compor os sentidos das questões de LP do Enem?

3. Como os multiletramentos são abordados nas questões analisadas e que habilidades de leitura são requeridas?

Para o corpus, a partir do objetivo geral e das minhas aspirações iniciais, selecionei oito questões do Enem. A seleção foi realizada entre as questões das primeiras edições do Enem do caderno azul de Linguagens, Códigos e suas Tecnologias dos anos de 2009 a 2016. Antes de seguir com a escolha do referencial teórico e as questões para análise, o primeiro passo foi discorrer sobre o início da minha caminhada, minha inspiração inicial.

No primeiro capítulo, apresentei a contextualização do meu objeto de análise: o Enem, com sua história social e legal. Apontei seus objetivos, sua organização, suas competências e habilidades do caderno de Linguagens, Códigos e suas Tecnologias a partir da matriz de referência e suas reformulações (em 2008 e em 2017).

No segundo capítulo, dissertei sobre os caminhos teóricos nos quais eu me baseei para a realização deste trabalho. Como principais teóricos, abordei Chouliaraki \& Fairclough (1999) e Fairclough (2001 [1992]; 2003) no que tange à Análise de Discurso Crítica (ADC); Tfouni (1988), Kleiman (1989; 1995; 2005; 2008; 2014), Barton (1994; 2002), Rios (2010; 2014) e Soares (2004) no que se refere ao Letramento em duas vertentes (cognitiva e sociocultural); Cope \& Kalantzis (2000);

Rojo e Moura (2012) para questões sobre os Multiletramentos; e Kress \& van Leeuwen (2001, 2006 [1996]) e Vieira (2007; 2010) para tratar de Multimodalidade. 
Quanto ao terceiro capítulo, apontei questões metodológicas pautadas em autores como Bauer e Gaskell (2000), Denzin (2006) e Flick (2013) para destacar a metodologia qualitativa de pesquisa de cunho social desenvolvida aqui. Ressaltei as categorias dos Multiletramentos e as categorias da Gramática do Design visual eleitas para a análise futura das questões; expliquei como foi realizada a seleção das questões do Enem para o corpus deste trabalho e quais foram os critérios.

O último capítulo, o quarto, trouxe pontos essenciais para o fechamento deste trabalho: o levantamento de dados das questões do Enem de 2009 a 2016; algumas questões norteadoras para a análise, construídas a partir dos objetivos deste estudo, e as análises das oito questões selecionadas por meio de categorias dos Multiletramentos e da Multimodalidade apontadas do capítulo metodológico e citadas neste último capítulo.

Durante e após as análises, verifiquei que boa parte dos comandos das questões discorrem a respeito do texto motivador, ressaltam a presença do texto mutlimodal com a combinação de elementos verbais e não verbais, para que o estudante tenha certeza de que se trata de um texto com mais de uma modalidade, isso orienta o estudante a selecionar a alternativa para a qual a estratégia argumentativa foi utilizada. A compreensão textual, portanto, requer leitura atenta das diversas modalidades.

Os significados textuais são compostos pelas modalidades verbal e não verbal, que se complementam para dar sentido aos textos motivadores e, assim, às questões. A partir dessas constatações, considerei que é importante que os estudantes mantenham contato com textos diversos e por meio de várias modalidades e mídias para que estejam familiarizados com esse tipo de leitura.

A composição dos textos motivadores requer do leitor uma experiência multiletrada, pois se trata de textos diversos, como panfletos, cartazes, tirinhas, infográficos, etc. Por isso, é necessário que os estudantes utilizem sua experiência como leitores com conhecimentos linguísticos e extralinguísticos adquiridos ao longo de sua vida escolar e extraescolar.

Percebi também que os textos analisados fazem parte de uma prática social comum - provas avaliativas do Enem, lidas e respondidas por estudantes de níveis de escolaridade distintos, a partir do ensino médio, e, pela prática social, os textos exigem conhecimentos formais e conhecimentos extralinguísticos para a compreensão das questões. 
Quanto à importância da imagem no texto, a análise me leva a crer que as imagens, em muitos casos, assumiram posição central na comunicação, pois deixaram de ser apenas um ícone para ser parte do texto ou o próprio texto, assim como afirma Vieira (2010, p. 54): “[...] o contexto não precisa ser obrigatoriamente verbal. Imagens podem abrigar outras imagens, funcionando elas mesmas como contextos de outras imagens". Na análise de dados, concluí que a escolha da imagem e a sua associação com o texto escrito está intrinsecamente ligada à mensagem que se deseja construir e também à opção por construir esse sentido recorrendo a múltiplas semioses.

Devo acentuar que as questões com textos multimodais por mim selecionadas, assim como outras que compõem as provas do Enem, abordam temas altamente relevantes para a sociedade e, em especial, para o público majoritário da prova: jovens alunos concluintes do Ensino Médio, ainda em fase de formação de sua consciência crítica. Por isso, considero relevante mencionar esse aspecto como elemento revelador do cuidado na escolha dos textos e das temáticas que são utilizadas nas provas.

Além disso, pondero que as provas do Enem, considerando os textos aqui analisados e sua composição geral, têm requerido dos alunos habilidades de leitura que extrapolam a compreensão do texto verbal. Charges, mapas, gráficos, cartazes requerem habilidades de compreensão do texto visual e, em especial, do texto multimodal. Por isso, editoras (responsáveis pela publicação de livros didáticos) escolas e professores devem voltar sua atenção para esse aspecto da formação leitora dos alunos na educação básica.

Vale ressaltar também que as competências de área (1, 5, 6, 7, 8 e 9) da matriz de referência de Linguagens, Códigos e suas Tecnologias se relacionam às competências de um leitor multiletrado (usuário funcional, criador de sentidos, analista crítico e transformador), pois as competências da matriz reúnem quesitos que se referem a leitores críticos como: a leitura de textos multimodais e atualizados, com recursos expressivos da linguagem em contextos relevantes; os recursos expressivos das linguagens e suas condições de produção; o uso de diferentes linguagens para constituição de significados e para confrontar opiniões diversas; a compreensão da língua materna como constituidora de significado; e a compreensão dos impactos das tecnologias de comunicação e seus processos de produção e de resolução de problemas.

Destaco que, nas questões analisadas, a relação entre os multiletramentos e a multimodalidade é ressaltada por meio de quesitos apontados por Rojo e Moura (2012) 
e aqui observados: a diversidade cultural e linguística percebida nos textos multimodais pelos diversos recursos semióticos utilizados e selecionados de modo a compor os significados de cada questão; e a multiplicidade de canais de comunicação e mídia requeridos aos estudantes leitores das questões, realçada pela presença de textos de vários gêneros discursivos e com diversas semioses que exigem do leitor convivência com linguagens e mídias que proporcionem leituras atualizadas e sofisticadas.

Por fim, considero que esta análise inicia estudos que precisam ser aprofundados para que possamos - como docentes e nativos da Língua Portuguesa - pensar em estratégias para disseminar o estudo do texto visual - a fim de, como consequência, consolidar o desenvolvimento de habilidades de leitura e de compreensão de textos não verbais. 


\section{REFERÊNCIAS}

ANTUNES, Irandé. Aula de português: encontro \& interação. São Paulo: Parábola Editorial, 2003.

BARTON, David. Literacy: an introduction to the ecology of written language. Londres: Blackwell, 1994.

BARTON, David. HAMILTON, Mary. IVANIC, Roz. (edit.) Situated Literacies: Reading and writing in context. London: Routledge, 2002.

BAUER, Martin W. \& GASKELL, George (Edited by). Qualitative Researching with Text, Image and Sound: a Practical Handbook. Los Angeles, London, New Delhi, Singapore: SAGE Publications Ltd, 2000.

BEVILAQUA, Raquel. Novos Estudos do Letramento e Multiletramentos: Divergências e Confluências. In: RevLet - Revista Virtual de Letras, v. 05, no 01, jan./jul, 2013, p. 99- 114.

BYRNE, Brian. Teorias sobre a aquisição da leitura. In: SNOWLING, Margaret J. \& HULME, Charles. (Orgs) A ciência da leitura. Porto Alegre: Penso, 2013, p. 123-137. CHOULIARAKI, L. e FAIRCLOUGH, N. Discourse in late modernity. Edinburgh: Edinburg University Press, 1999.

COPE, Bill \& KALANTZIS, Mary. (Edited by) Multiliteracies: Literacy learning and the design of social futures. London and New York: Routledge, 2000.

DENZIN, Norman K. O planejamento da pesquisa qualitativa: teorias e abordagens./ Norman K.. Denzin, Yvonna S. Lincoln; tradução Sandra Regina Netz. Porto Alegre: Artmed, 2006.

Enem de 2015. Disponível em: http://portal.mec.gov.br/component/content/article?id=30781. Acesso em Acesso em: 29 mai. 2015.

FAIRCLOUGH, Norman \& MAGALHÃES, Izabel (coordenadora da tradução, revisão técnica e prefácio). Discurso e mudança social. Brasília: Editora Universidade de Brasília, 2001.

Analysing Discourse: textual analysis for social recearch. London: Routledge, 2003. 
FERRAZ, Janaína de Aquino. A formação do Brasileiro: um Enfoque Multimodal. Dissertação de mestrado. Brasília, 2005. In: VIEIRA, Josenia Antunes; BENTO, André Lúcio. Discurso, Identidade e Gênero. Brasília: Editora Movimento, 2015, p. 361- 449. FLICK, Uwe. Introdução à metodologia de pesquisa. Tradução: Magda Lopes. Porto Alegre: Penso, 2013.

HODGE, Robert. KRESS, Gunther. Social Semiotics. Oxford: Polity Press, 1991.

KLEIMAN, Ângela. Texto e leitor. Aspectos cognitivos da leitura. Campinas: Pontes, 1989.

. (Org.) Os significados do letramento. Campinas, SP: Mercado de Letras, 1995.

Preciso "ensinar" o letramento? Não basta ensinar a ler e a escrever? Cefiel/ IEL/ Unicamp, 2005

Os estudos de letramento e a formação do professor de língua materna. Linguagem em (Dis)curso - LemD, v. 8, n. 3, p. 487-517, set./dez. 2008.

. Letramento na contemporaneidade. Bakhtiniana, São Paulo, 9 (2): 72-91, Ago./Dez. 2014.

KRESS, Gunther. Multimodality. In B. Cope \& M. Kalantizis. Multiliteracies. London: Routledge, 2000.

KRESS, Gunther. R. \& van LEEUWEN, Teo. Multimodal Discourse: the modes and media of contemporary communication. London: Arnold, 2001.

Reading Images: a Grammar of Visual Design. Second edition. London and New York: Routledge, 2006.

MARCUSCHI, Luiz Antônio. Produção textual, análise de gêneros e compreensão. São Paulo: Parábola Editorial, 2008.

Matrizes de referência. Disponível em: http://portal.inep.gov.br/matriz-de-referencia Acesso em 27 mar. 2017.

MEC oficializou as mudanças do Enem 2017. Disponível em: http://www.enem2017.com/mec-oficializou-mudancas-enem-2017.html Acesso em 21 mai. 2017.

MELlO, Maria Cristina de \& RIBEIRO, Amélia Escotto do Amaral. (Orgs.) Letramento: significados e tendências. Rio de Janeiro: Wak, 2004.

PERFETTI, Charles A. LANDI, Nicole. OAKHILL, Jane. Aquisição de habilidade de compreensão da leitura. Os correlatos sociais do letramento emergente. In: 
SNOWLING, Margaret J. \& HULME, Charles. (Orgs) A ciência da leitura. Porto Alegre: Penso, 2013.

PHILLIPS, Beth M. \& LONIGAN, Christopher J. Os correlatos sociais do letramento emergente. In: SNOWLING, Margaret J. \& HULME, Charles. (Orgs) A ciência da leitura. Porto Alegre: Penso, 2013.

RIOS, Guilherme. Letramento, discurso e gramática funcional. Cadernos de Linguagem e Sociedade. Brasília, DF: UnB, 2010a. v. 11 (2), p. 167-183

Considerações sobre letramento, escolarização e avaliação educacional. In: RESENDE, Viviane de Melo; PEREIRA, Fábio Henrique. (Orgs.) Práticas Socioculturais e Discurso: Debates Transdisciplinares. Covilhã: LabCom Books, 2010b, p. 77-108.

Culturas, Discurso-de-Letramento e Práticas Escolares. In: GUERRA, Vânia Maria Lescano; NASCIMENTO, Celina Aparecida Garcia de Souza; SOUZA, Claudete Cameschide. (Orgs.) Sociedades Contemporâneas: diversidade e transdisciplinaridade. São Paulo: Pontes Editores, 2016, p. 55-85.

ROJO, Roxane. O letramento escolar e os textos da divulgação científica - a apropriação dos gêneros de discurso na escola. Linguagem em (Dis)curso - LemD, v. 8, n. 3, p. 581-612, set./dez. 2008

ROJO, Roxane. \& MOURA, Eduardo. (Org). Multiletramentos na escola. São Paulo: Parábola Editorial, 2012.

SCHOLZE, Lia \& ROSING, Tania M. K. (organização). Teorias e práticas do letramento. Brasília: Instituto Nacional de Estudos e Pesquisas Educacionais Anísio Teixeira, 2007.

SNOWLING, Margaret J. \& HULME, Charles. (Orgs) A ciência da leitura. Porto Alegre: Penso, 2013.

SOARES, Magda. Letramento e alfabetização: as muitas facetas. Universidade Federal de Minas Gerais, Centro de Alfabetização, Leitura e Escrita. Revista Brasileira de Educação, $N^{\circ}$ 25. Trabalho apresentado no GT Alfabetização, Leitura e Escrita, durante a $26^{\mathrm{a}}$ Reunião Anual da ANPEd, realizada em Poços de Caldas, MG, de 5 a 8 de outubro de 2003. Jan /Fev /Mar/Abr 2004a

Letramento e escolarização RIBEIRO, Vera M. (Org.) Letramento no Brasil. 2 ed. São Paulo: Global, 2004b, p. 89-113. 
Letramento: um tema em três gêneros. $2^{\mathrm{a}} \mathrm{Ed}$. Belo Horizonte: Autêntica, 2004c.

SOARES, Neiva Maria Machado. \& VIEIRA, Josenia Antunes. Representação Multimodal dos Atores Sociais no Discurso de Marcas. SIGNUM: Estud. Ling., Londrina, n. 16/1, p. 233-258, jun. 2013

Sobre o ENEM. Disponível em: <http:// portal.inep.gov.br/ /web/enem/sobre-o-enem >. Acesso em: 15 mai. 2015.

STREET, Brian. Social literacies: critical approaches to literacy in development, ethnography and education. London: Longman,1995.

TFOUNI, Leda Verdiani. Adultos não alfabetizados: o avesso do avesso. Campinas, São Paulo: Pontes, 1988.

TRAJANO, Izabella da Silva Negrão. A Imagem como Agente de Representação Social e Ideológica no Discurso Multimodal. Tese de Doutorado. Brasília, 2013.

Tudo sobre o ENEM 2014. Disponível em: <http:// www.infoenem.com.br/ tudosobre-o-enem-2014/>. Acesso em: 29 mai. 2015.

VIEIRA, Josenia Antunes; FERRAZ, Janaína de Aquino. Percursos e avanços do texto multimodal: novas perspectivas na contemporaneidade. In: VIEIRA, Josenia Antunes; BENTO, André Lúcio (Orgs.). Revista Discursos Contemporâneos em Estudo. Brasília: Universidade de Brasília, 2011. Vol. 1, n. 1, p. 9-23.

VIEIRA, Josenia Antunes. Reflexões sobre a língua portuguesa: uma abordagem multimodal/ VIEIRA, Josenia Antunes; ROCHA, Harrison da; MAROUN, Cristiane R. G. Bou; FERRAZ, Janaína de Aquino. Petrópolis, RJ: Vozes, 2007.

A contribuição do letramento multimodal para os multiletramentos. In: Linguagem em foco. Revista do Programa de Pós-Graduação em Linguística Aplicada da UECE, v. 2, nº 2, ano 2010. 